DOE/NASA/0182-1

NASA CR-165566

\title{
Fatigue Testing of Low-Cost Fiberglass Composite Wind Turbine Blade Materials
}

K. E. Hofer and L. C. Bennett

IIT Research Institute

November 1981

Prepared for

NATIONAL AERONAUTICS AND SPACE ADMINISTRATION Lewis Research Center

Under Contract DEN 3-182

LIBRARY COPY

for

U.S. DEPARTMENT OF ENERGY

$1.3-1983$

Conservation and Renewable Energy Wind Energy Technology Division

LANGLEY RESEARCH CENTER LIBRARY, NASA HAMPTON, VIRGINIA 


\section{NOTICE}

This report was prepared to document work sponsored by the United States Government. Neither the United States nor its agent, the United States Department of Energy, nor any Federal employees. nor any of their contractors. subcontractors or their employees, makes any warranty, express or implied, or assumes any legal liability or responsibility for the accuracy, completeness, or usefulness of any information. apparaius, product or process disclosed. or represents that its use would not infringe privately owned rights. 
DOE/NASA/0182-1

NASA CR-165566

\section{Fatigue Testing of Low-Cost Fiberglass Composite Wind Turbine Blade Materials}

K. E. Hofer and L. C. Bennett

IIT Research Institute

Chicago, Illinois 60616

November 1981

Prepared for

National Aeronautics and Space Administration

Lewis Research Center

Cleveland, Ohio 44135

Under Contract DEN 3-182

for

U.S. DEPARTMENT OF ENERGY

Conservation and Renewable Energy

Wind Energy Technology Division

Washington, D.C. 20545

Under Interagency Agreement DE-AI01-79ET20320

$$
1783-227464
$$



TABLE OF CONTENTS

Page

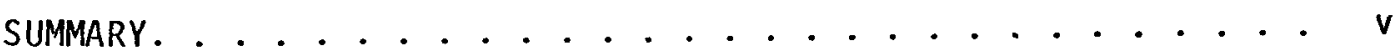

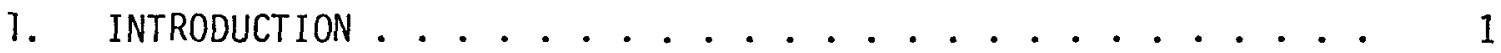

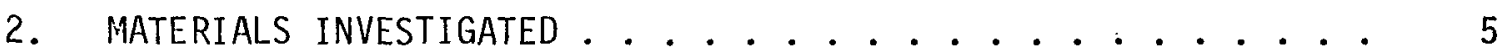

3. StATIC ANd Fatigue BehaviOR. ............ 17

3.1 Baseline Static Mechanical Data .......... 17

3.2 Effect of Moisture on Fatigue Life. . . . . . . 22

3.3 Effect of Mean Stress on Fatigue Life . . . . . . . 22

4. SUMMARY OF RESULTS ............................. 25

REFERENCES. ........................ 26

APPENDIX A: TEST PROCEDURES FOR MECHANICAL TESTING OF TRANSVERSE FILAMENT TAPE FIBERGLASS/EPOXY AND POLYESTER MATRIX

COMPOSITES . . . . . . . . . . . 27

APPENDIX B: STATIC MECHANICAL PROPERTIES OF EPOXY MATRIX

AND POLYESTER MATRIX COMPOSITES. . . . . . . . 55

APPENDIX C: INDIVIDUAL FATIGUE DATA. . . . . . . . 77 



\section{SIJMMARY}

This is the final report, NASA CR-165566, on IIT Research Institute (IITRI) Program No. IITRI-M06066-22 entitled, "Fatigue Testing of Low-Cost Fiberglass Composite Wind Turbine Blade Materials." This program was performed during the period from 10 November 1979 to 30 September 1981 in the Materials and Manufacturing Technology Division of IITRI. The IITRI Program Manager was Mr. K. E. Hofer; substantial contributions to the program were made by Mssrs. L. C. Bennett, G. Skaper, and V. Humphreys. Mssrs. R. Lark and T. Sullivan acted as Program Monitors on behalf of NASA-Lewis Research Center.

The static and fatigue behavior of transverse filament tape (TFT) fiberglass/epoxy and TFT fiberglass/polyester composites was established by the testing of specimens cut from panels fabricated by a filament winding process used for the construction of large experimental wind turbine blades. Static mechanical properties obtained included tension, compression, and interlaminar shear at ambient conditions and in high humidity/high temperature conditions after a 500-hour exposure to such an environment. The fatigue data were obtained at similar environmental exposures and at several $R$ ratios, including $R=0,-0.1,-0.25,-0.5$, and -1 . Negative ratios imply a compressive component of stress. Testing was performed to failure in many cases.

S-N diagrams and a modified Goodman constant 7 ife plot were obtained for one of two of the epoxy matrix composites.

The elastic properties of the epoxy matrix materials showed a strong dependence only on the filament stiffness and angle between the load direction and the filament, and a weak influence of the high humidity/ high temperature environment. The polyester materials showed a substantial decrease in compressive strength for some composites which had been exposed for over 4000 hours in the high humidity/high temperature environment. 



\section{INTRODUCTION}

After many years of cheap and abundant energy availability, recent global events indicated the need for full utilization of all available energy resources (Ref 1-6).* One such resource may be harvested by utilization of wind energy conversion systems. The blade materials for wind energy conversion systems are critical for several reasons.

- The stability of the blades is related to the stiffness of the materials used

- The strength and long term durability of the system are linked to the static strength and fatigue endurance of the blade materials

- The utilization of the system depends upon the costs of the blade and the biade costs depend upon the component material and fabrication costs.

One candidate material which appears to have the potential for resolution of the problem areas associated with wind energy conversion systems (WECS) and the properties required for the success of WECS is glass fiberreinforced plastic (Ref 7-9).

The program described herein was undertaken to provide data in support of the NASA low-cost blade development program. The mechanical properties of transverse filament tape (TFT) fiberglass reinforced plastic were established by the testing of specimens cut from panels which had been fabricated by Structural Composites Industries (SCI) under contract DEN3-100.

A static test program was conducted in accordance with the plan shown in Table 1. Testing was conducted at both ambient conditions $\left[T=21^{\circ} \mathrm{C}\left(70^{\circ} \mathrm{F}\right)\right.$ and R.H. $=50 \%]$ and at elevated temperature and humidity $\left[\mathrm{T}=49^{\circ} \mathrm{C}\left(120^{\circ} \mathrm{F}\right)\right.$ and R.H. = 98\%]. The fatigue program shown in Table 2 was also conducted at ambient conditions and elevated temperature-humidity conditions.

* Numbers in parentheses refer to the references at the end of this report. 


\section{TABLE 1. STATIC TEST PROGRAM}

\begin{tabular}{|c|c|c|c|c|c|c|}
\hline \multirow{2}{*}{$\begin{array}{c}\text { General } \\
\text { Material Type }\end{array}$} & \multirow{2}{*}{$\begin{array}{l}\text { Winding } \\
\text { Pattern }\end{array}$} & \multirow[b]{2}{*}{ Preconditioning } & \multirow{2}{*}{$\begin{array}{c}\text { Test } \\
\text { Conditions } \\
\end{array}$} & \multicolumn{3}{|c|}{$\begin{array}{c}\text { Minimum Number of } \\
\text { Specimens Per Property }\end{array}$} \\
\hline & & & & Tension & Compression & Shear \\
\hline \multirow[t]{4}{*}{ TFT/epoxy } & $1^{a}$ & $d r y^{c}$ & dry & 5 & 5 & 5 \\
\hline & & wet ${ }^{d}$ & wet & 5 & 5 & 5 \\
\hline & $2^{b}$ & dry & dry & 5 & 5 & 5 \\
\hline & & wet & wet & 5 & 5 & 5 \\
\hline \multirow[t]{2}{*}{ TFT/polyester } & 2 & dry & dry & 5 & 5 & 5 \\
\hline & & wet & wet & 5 & 5 & 5 \\
\hline
\end{tabular}

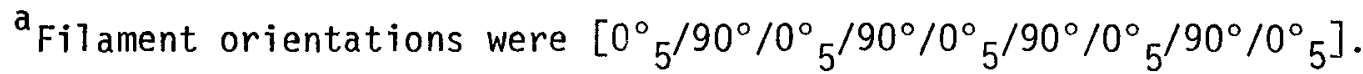

$b_{F i l a m e n t}$ orientations were $\left[0^{\circ}{ }_{5} / 90^{\circ} / \pm 45^{\circ} / 90^{\circ} / 0^{\circ}{ }_{5} / 90^{\circ} / 0^{\circ}{ }_{5} / 90^{\circ} / \pm 45^{\circ} / 90^{\circ} / 0^{\circ}{ }_{5}\right]$.

$C_{\text {Dry }}=21^{\circ} \mathrm{C}\left(70^{\circ} \mathrm{F}\right)$, R.H. $=50 \%$.

$d_{\text {Wet }}=49^{\circ} \mathrm{C}\left(120^{\circ} \mathrm{F}\right), R_{0} H_{.}=98 \%$ for 500 hours. 


\section{TABLE 2. FATIGUE TEST PROGRAM}

\begin{tabular}{|c|c|c|c|c|c|c|}
\hline \multirow[b]{2}{*}{ Material Type } & \multirow{2}{*}{$\begin{array}{l}\text { Test Conditions, } \\
\text { Temperature/Humidity }\end{array}$} & \multicolumn{5}{|c|}{ Number of Specimens Per $R^{*}$ Ratio } \\
\hline & & $R=0$ & $R=-0.1$ & $R=-0.25$ & $R=-0.5$ & $R=-1$ \\
\hline \multirow{2}{*}{$\begin{array}{l}\text { TFT/epoxy; } \\
\text { Winding Pattern } \\
\text { No. } 1\end{array}$} & $21^{\circ} \mathrm{C}\left(70^{\circ} \mathrm{F}\right) / 50 \%$ R.H. & 12 & 8 & 5 & 5 & 5 . \\
\hline & $49^{\circ} \mathrm{C}\left(120^{\circ} \mathrm{F}\right) / 98 \%$ R.H. & 5 & 5 & 5 & 5 & 5 \\
\hline \multirow{2}{*}{$\begin{array}{l}\text { TFT/epoxy; } \\
\text { Winding Pattern } \\
\text { No. } 2\end{array}$} & $21^{\circ} \mathrm{C}\left(70^{\circ} \mathrm{F}\right) / 50 \%$ R.H. & 12 & 5 & 5 & 5 & 5 \\
\hline & $49^{\circ} \mathrm{C}\left(120^{\circ} \mathrm{F}\right) / 98 \%$ R.H. & 5 & 5 & 5 & 5 & 5 \\
\hline \multirow{2}{*}{$\begin{array}{l}\text { TFT/polyester; } \\
\text { Winding Pattern } \\
\text { No. } 2\end{array}$} & $21^{\circ} \mathrm{C}\left(70^{\circ} \mathrm{F}\right) / 50 \%$ R.H. & 5 & 5 & - & - & 5 \\
\hline & $49^{\circ} \mathrm{C}\left(120^{\circ} \mathrm{F}\right) / 98 \%$ R.H. & 5 & 5 & - & - & 5 \\
\hline
\end{tabular}


The fatigue stress ratio included values of $R$ from 0 to -1.0 . This implied compressive components of stress and, consequently, required stabilization of the specimen during fatigue stroking. At $\phi=0.5$ hertz, 250 days would be required to amass $10^{7}$ cycles. This time level was unacceptable, and hence, acceleration of the tests was necessary. Fan-induced airflow across the specimen was the method of cooling. Temperatures never exceeded $78^{\circ} \mathrm{F}$ for ambient conditions and $120^{\circ} \mathrm{F}$ for elevated temperature/humidity conditions.

This report describes the results of all testing conducted during the program. A description of the materials investigated during this program is found in Chapter 2 of this report. Details of the test procedures for the mechanical testing, including specimen configuration, preparation preliminary efforts, and environmental exposures are presented in Appendix $A$ to this report. Individual static mechanical properties results and failure modes are presented in Appendix B. Individual specimen fatigue endurances and a description of fatigue failure modes are presented in Appendix $C$. The static and fatigue results are capsulized in Chapter 3 of this report; Chapter 4 presents conclusions based upon the results. 


\section{MATERIALS INVESTIGATED}

A11 Taminated materials investigated during this program were furnished by NASA-LeRC. Panels were manufactured and submitted to IITRI by the fabricator, Structural Composites Industries (SCI) under Contract DEN3-100.

The basic reinforcing element in the panels was a 7 in. wide transverse filament tape (TFT) which consisted of bundles of glass filaments supported by two carrier threads. The carrier threads permit the use of filament winding procedures in the fabrication of structural elements. With an appropriate overlap ( $3 \mathrm{in.}$ ) of the TFT, the resulting laminate will have an adequate number of the filaments in the direction of the principal stresses in the structural component. The laminates prepared for testing contained $0^{\circ}, 90^{\circ}$, and $\pm 45^{\circ}$ filaments.

Two winding patterns were investigated with an epoxy matrix: Winding Pattern No. 1 was a $0^{\circ}$ and $90^{\circ}$ layup and represented the pattern used to produce an experimental 150-ft TFT fiberglass wind turbine blade (10); Winding Pattern No. 2 contained $0^{\circ}, 90^{\circ}$, and \pm 45 filaments and represented the pattern used to produce two 60-ft experimental fiberglass blades (11). See Table 3 for the ply-by-ply description of these two winding patterns.

The TFT weight for this study was $7 \mathrm{oz} / \mathrm{sq} y \mathrm{~d}$, compared with a $36 \mathrm{oz} / \mathrm{sq}$ yd material used to prepare the $150 \mathrm{ft}$ TFT blade. For the epoxy matrix composites an epoxy system containing DER 332 with RD-2 diluent and Tonex 6040 hardener was used.

During fabrication $1.5 \%$ of Cab-0-Si1 was added to the mix for thixotropic properties (to provide control of resin flow during blade winding). For the polyester laminates the resin used was Polylite $A 27623^{a}$ catalyzed by using equal amounts of cumenehyperoxide ${ }^{b}$ and Percodox $16 \mathrm{~N} .^{C}$ No attempt was made to optimize the selection of polyester resin by test.

\footnotetext{
${ }^{\mathrm{a}} \mathrm{A}$ product of Reichold Chemical Co.

$b_{A}$ product of Lucidol Co.

$C_{A}$ product of Novry Chemical Co.
} 
TABLE 3. LAYUP SCHEDULE FOR WINDING PATTERN NOS. 1 AND 2

\begin{tabular}{|c|c|c|c|}
\hline $\begin{array}{l}\text { Winding } \\
\text { Pattern } \\
\end{array}$ & $\begin{array}{c}\text { Ply } \\
\text { Designation } \\
\end{array}$ & $\begin{array}{l}\text { Ply Angle } \\
\text { (Degrees) }\end{array}$ & $\begin{array}{l}\text { Number } \\
\text { of Plies }\end{array}$ \\
\hline \multirow[t]{9}{*}{1} & $\mathrm{TFT}^{\mathrm{a}}$ & $0^{\circ}$ & $5^{e}$ \\
\hline & $L F T^{b}$ & $90^{\circ}$ & 1 \\
\hline & TFT & $0^{\circ}$ & 5 \\
\hline & LFT & $90^{\circ}$ & 1 \\
\hline & TFT & $0^{\circ}$ & 5 \\
\hline & LFT & $90^{\circ}$ & 1 \\
\hline & TFT & $0^{\circ}$ & 5 \\
\hline & LTF & $90^{\circ}$ & 1 \\
\hline & TFT & $0^{\circ}$ & 5 \\
\hline \multirow[t]{11}{*}{2} & TFT & $0^{\circ}$ & 5 \\
\hline & LFT & $90^{\circ}$ & 1 \\
\hline & $B F T^{C}$ & $\pm 45^{\circ}$ & 1 \\
\hline & $\mathrm{LFT}$ & $90^{\circ}$ & 1 \\
\hline & TFT & $0^{\circ}$ & 5 \\
\hline & LFT & $90^{\circ}$ & 1 \\
\hline & TFT & $0^{\circ}$ & 5 \\
\hline & LFT & $90^{\circ}$ & 1 \\
\hline & BFT & $\pm 45^{\circ}$ & 1 \\
\hline & LFT & $90^{\circ}$ & 1 \\
\hline & TFT & $0^{\circ}$ & 5 \\
\hline
\end{tabular}

Transverse filament tape, 7 oz/yd ${ }^{2}, 7$ in. wide.

bongitudina 1 filament tape, $100 z / y d^{2}, 3$ in. wide.

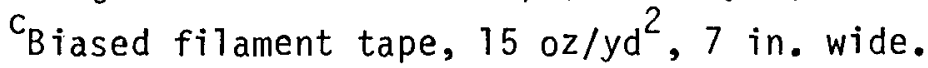

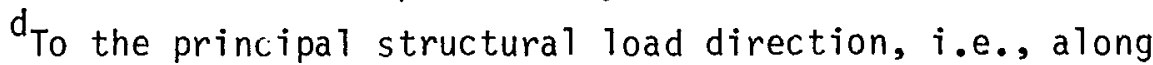
the length of the blade.

${ }^{e}$ Although five successive passes of the TFT were made, the tape was laid down with a 4 in. overlap, thus producing a total of approximately 2-1/3 layers per pass; thus, the ratio of $0^{\circ}$ filaments to $90^{\circ}$ filaments for Winding Pattern No. 1 is approximately 15:1. 
During fabrication of the turbine blade, the tapes are wound in such a way that a 3 in. overlap in the direction of the fibers is developed. This overlap assists in transferring load along the length of the fibers from one tape to the next. The $3 \mathrm{in}$. overlap results in the fibers being oriented at a small angle to the principal stress direction, about $2^{\circ}$. A small preliminary test program was conducted to identify whether the main body of test specimens should be cut with the specimens oriented at $0^{\circ}$ or at $2^{\circ}$ to filament direction. The procedures and test results of that program are described in Appendix A.

There was some difficulty in assessing the principal fiber direction from the panels provided, since no accurate reference lines were present. The zero direction was taken as the direction $90^{\circ}$ to the average direction of the tracing threads. Even this was often difficult to establish. Figure 1 shows the direction of fibers along the length of a sample determined by prying the fibers from the surface of the sample and measuring their direction relative to the assumed $0^{\circ}$ direction. Fiber direction, on both the top and bottom surfices of the sample, was obtained, and is shown plotted in Fig. 1. As can be seen, the surface fiber directions vary as much as $+8^{\circ}$ and $-10^{\circ}$ from the assumed fiber direction. In addition, the internal ply directions will also vary from $0^{\circ}$. The testing of specimens at $2^{\circ}$ to the blade direction was clearly not as significant as originally designed.

Furthermore, as the test results presented in Appendix A illustrate, there was no significant difference between samples prepared at $0^{\circ}$, the principal fiber direction, and samples prepared at $2^{\circ}$ to the principal fiber direction. The decision was made to conduct all further static and fatigue testing at $0^{\circ}$ to the principal fiber direction.

Although the panels of epoxy matrix composites had all been subjected to routine nondestructive inspection by ultrasonic C-scan by NASA prior to shipment to IITRI, the polyester panels had not. As a consequence, the polyester panels were subjected to $\mathrm{C}$-scan by IITRI prior to specimen preparation. The apparatus shown in Fig. 2 was utilized for this purpose.

Figures 3 and 4 show the attenuation versus position and C-scans for a trial sample at 7 and $5 \mathrm{MHz}$, respectively, in the pulse-echo mode. The $1 \mathrm{MHz}$ pulse-echo scan was repeated after overnight immersion, to eliminate air 


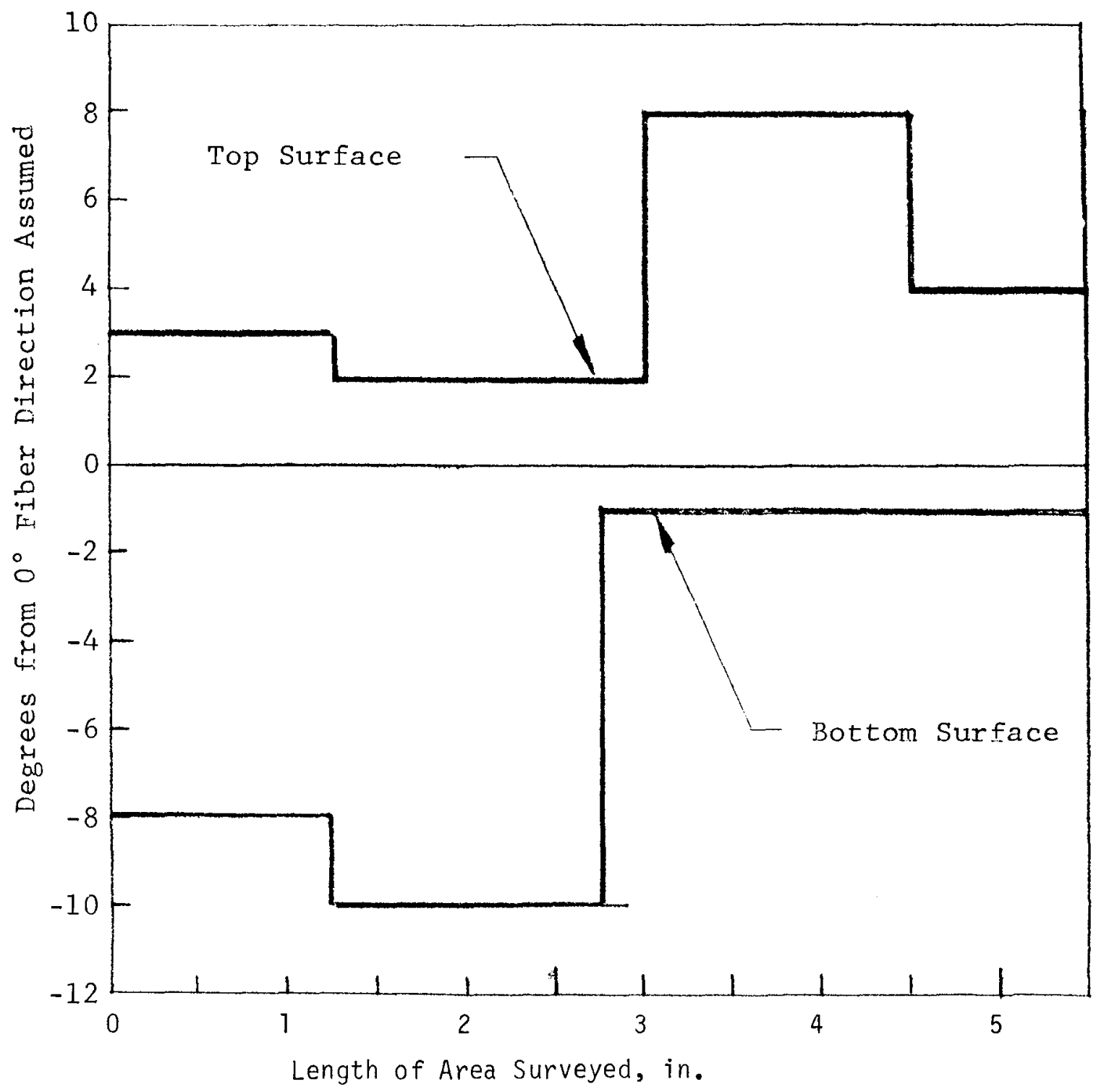

Figure 1. Direction of fibers relative to assumed $0^{\circ}$ fiber direction. 


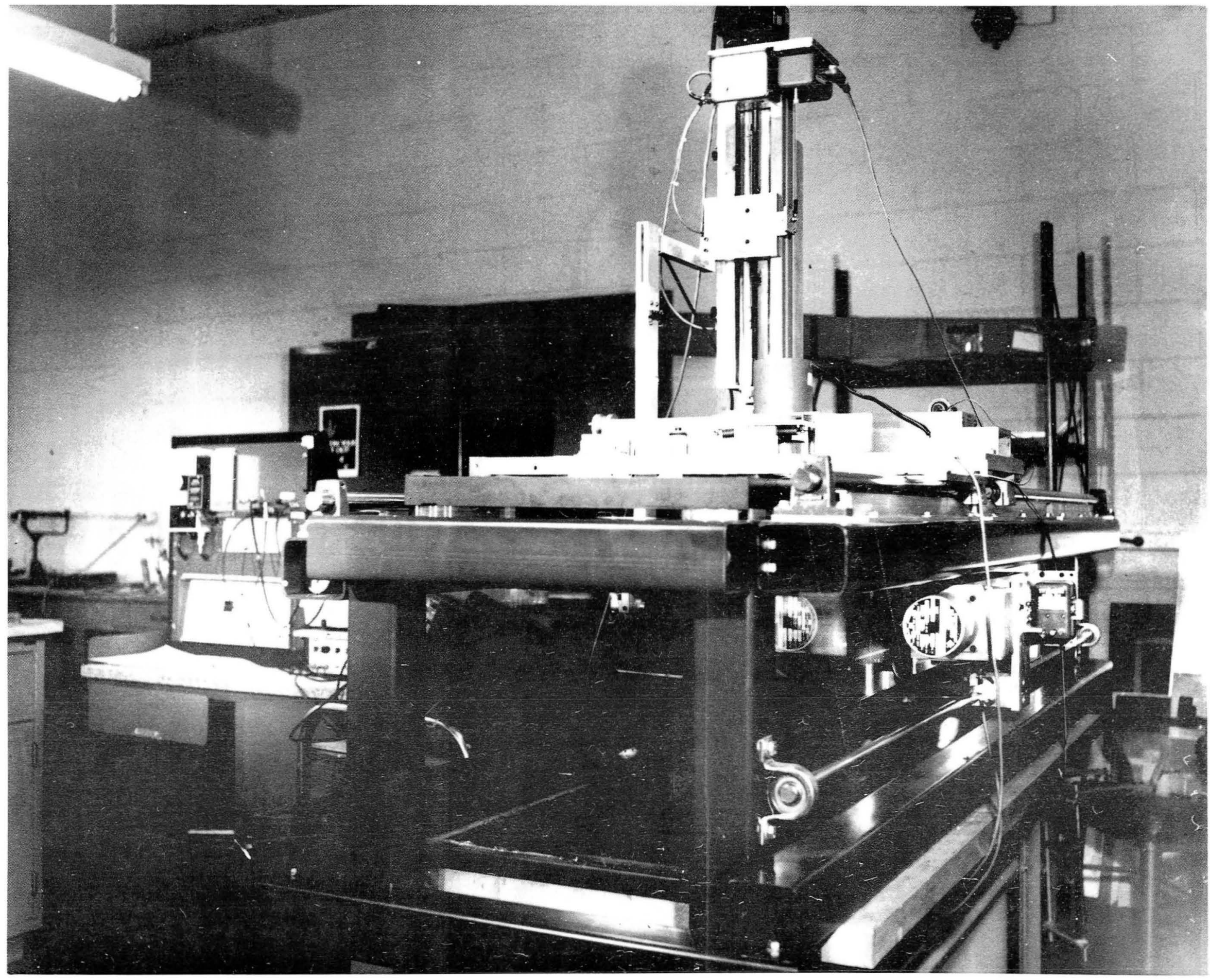

Figure 2. Nondestructive ultrasonic scanning system for inspecting wind turbine blade materials. 


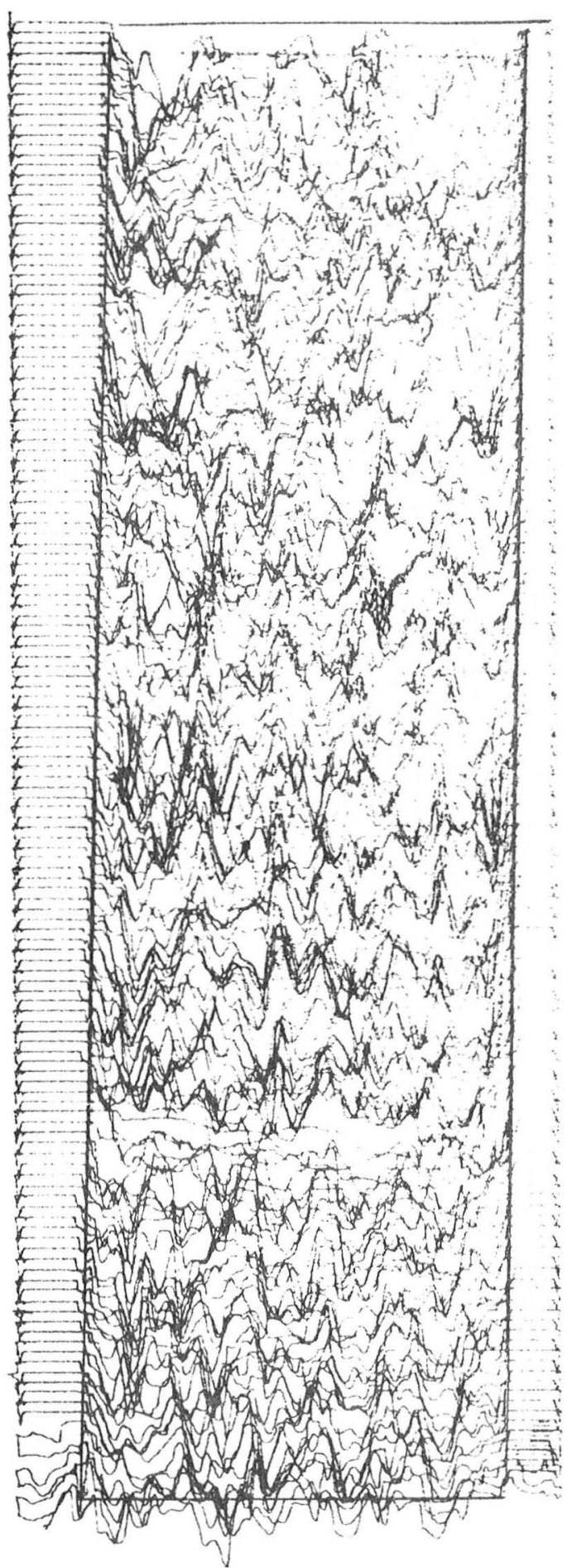

(a)

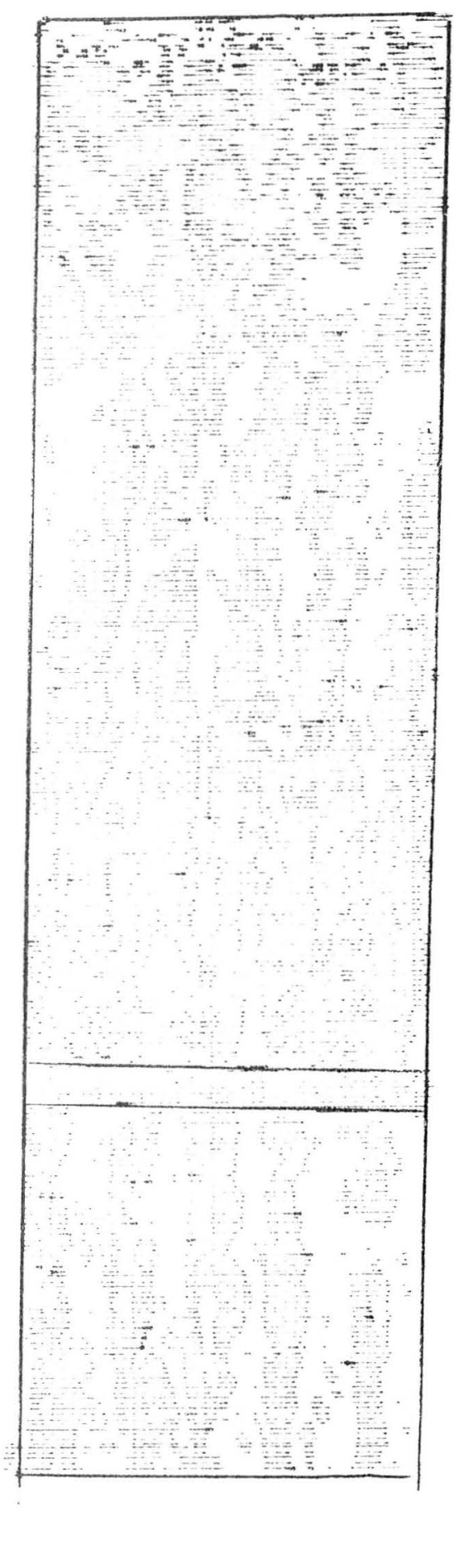

(b)

Figure 3. Specimen scanned at 1 Megahertz (pulse-echo mode). a) db attenuation versus position along various traversing paths in pane1; b) gated scan with pen-paper contact only when attenuation is less than a fixed level. 


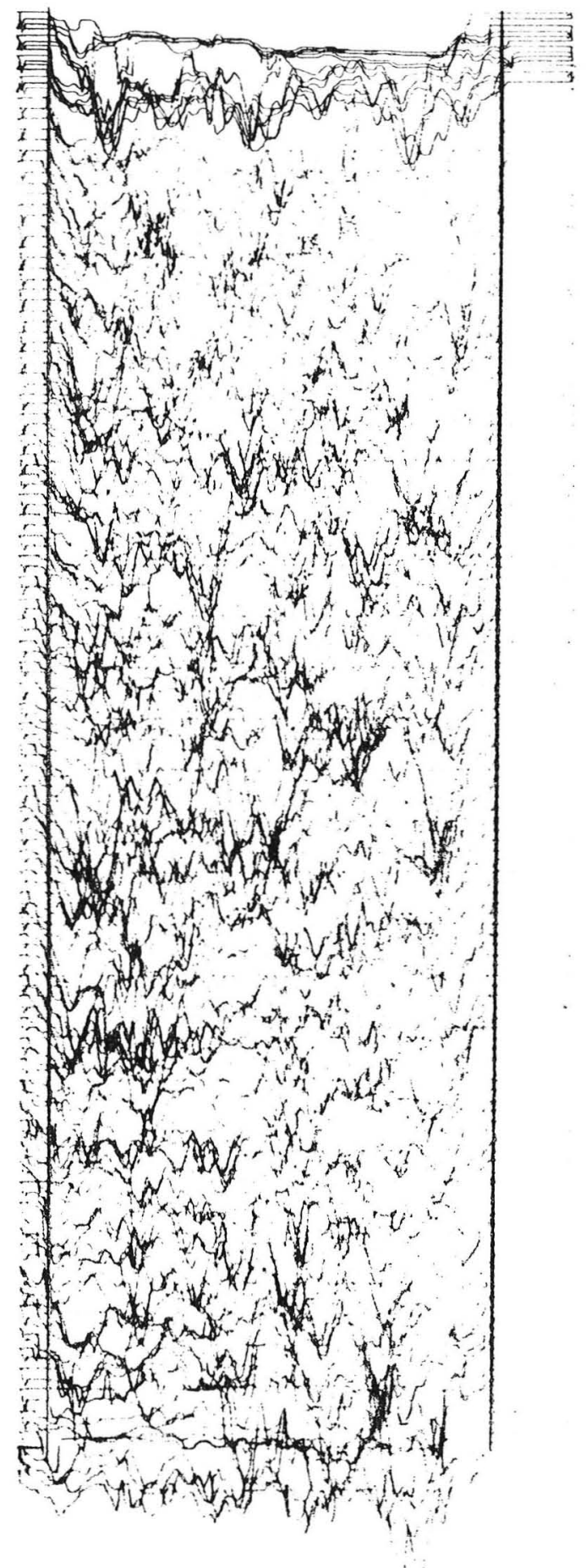

(a)

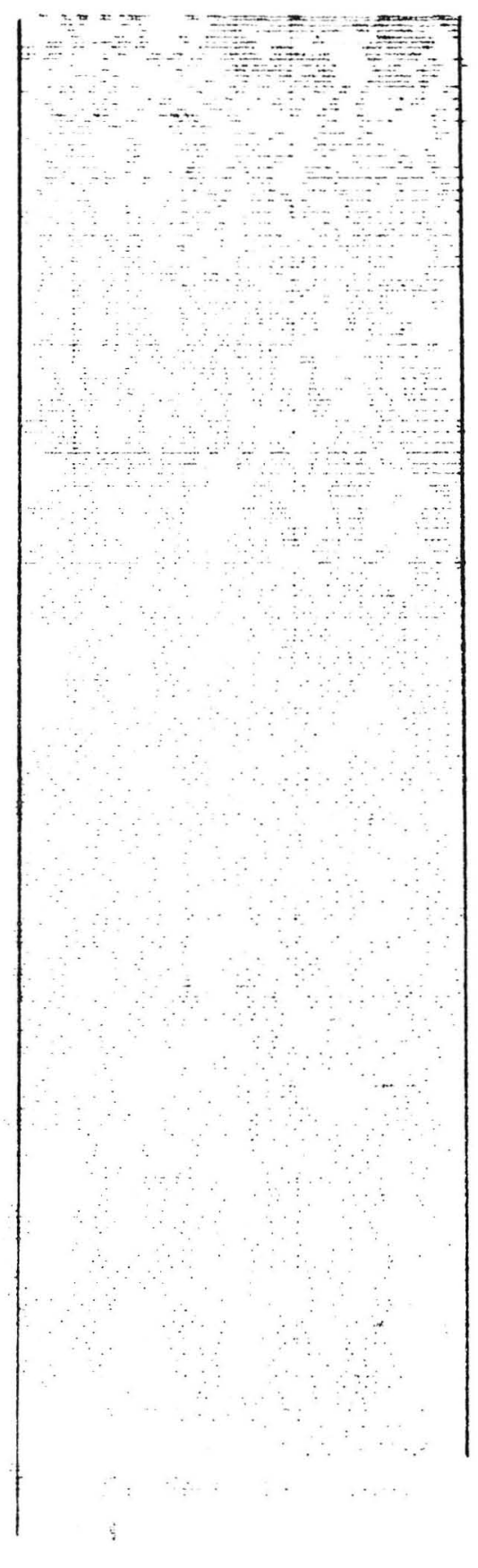

(b)

Figure 4. Specimen scanned at 5 Megahertz (pulse-echo mode). a) db attenuation versus position along various traversing paths in pane1; b) gated scan with pen-paper contact only when attenuation is less than a fixed level. 
bubbles possibly attached to the surface. Figure 5 shows the results. No improvement over the scan shown in Figure 3 was evident. Finally, a throughtransmission scan was performed for the same sample. Figure 6 shows those results.

Finally, using the best available techniques the two polyester matrix panels provided to IITRI by NASA were nondestructively tested using ultrasonic pulse-echo at an excitation frequency of the transducer of $1 \mathrm{MHz}$. The complete uTtrasonic C-scans for panels $4 A$ and $4 B$ are shown in Figs. 7 and 8 . Both panels show numerous indications of regular gaps or flaws parallel to the filaments in the transverse filament tape.

Since no section of the panels appeared to be free of the gap, each and every section was similar to every other section. Specimens were, therefore, prepared from the panels with typical "gap" levels present in every specimen. 


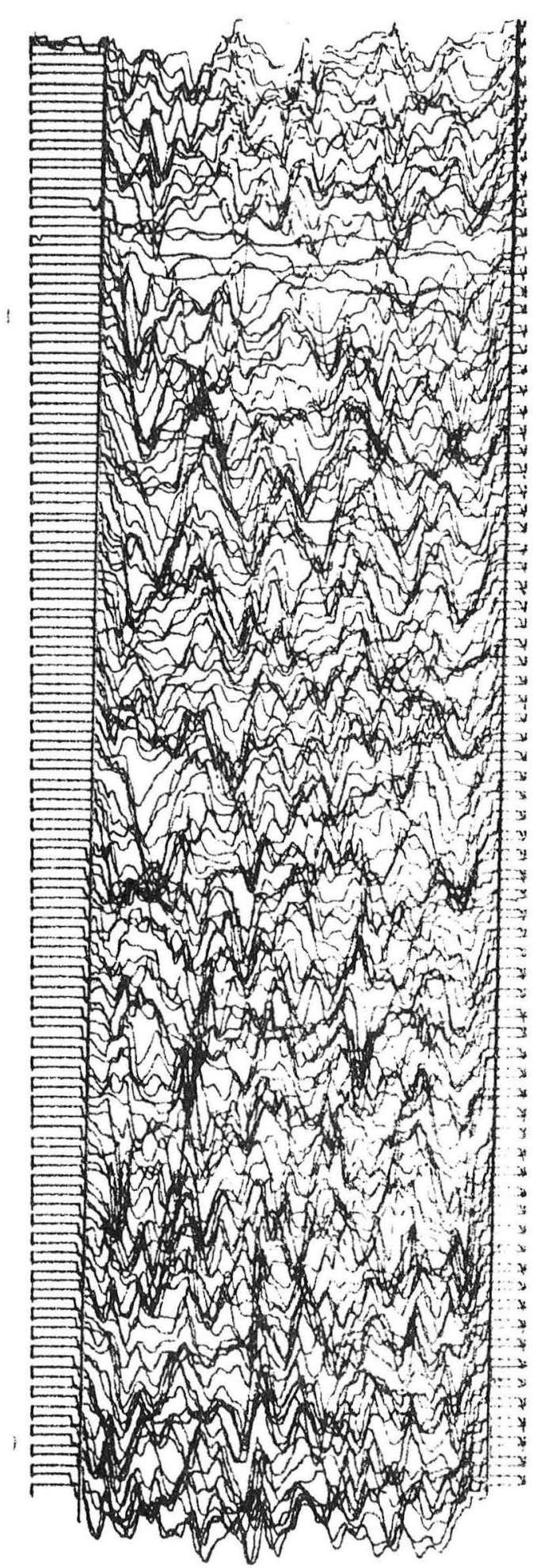

(a)

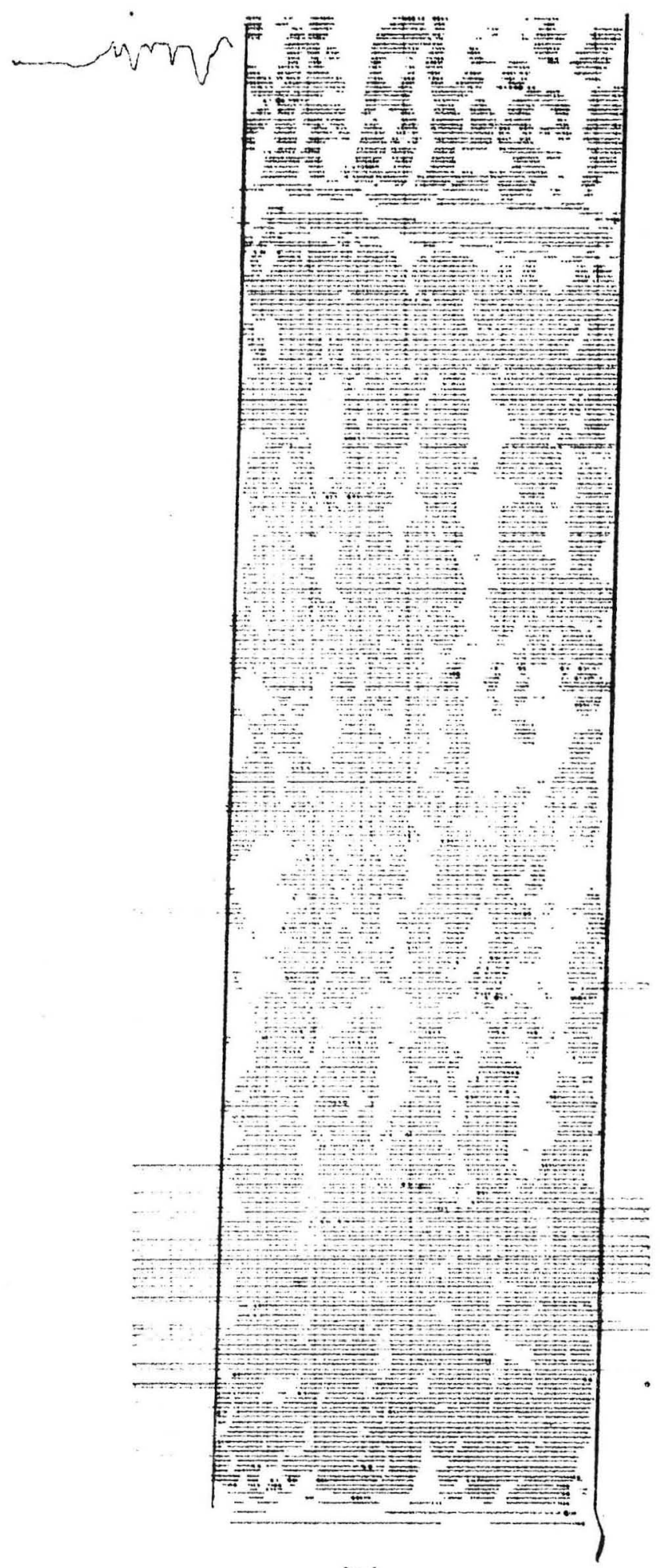

(b)

Figure 5. Same sample as shown in Figure 1 tested at 1 Megahertz pulseecho mode after 24 hours immersion to eliminate air bubbles. a) db attenuation versus position along various traversing paths in panel; (b) same panel with a qated scan with pen-paper contact only when attenuation is less than some fixed level. 


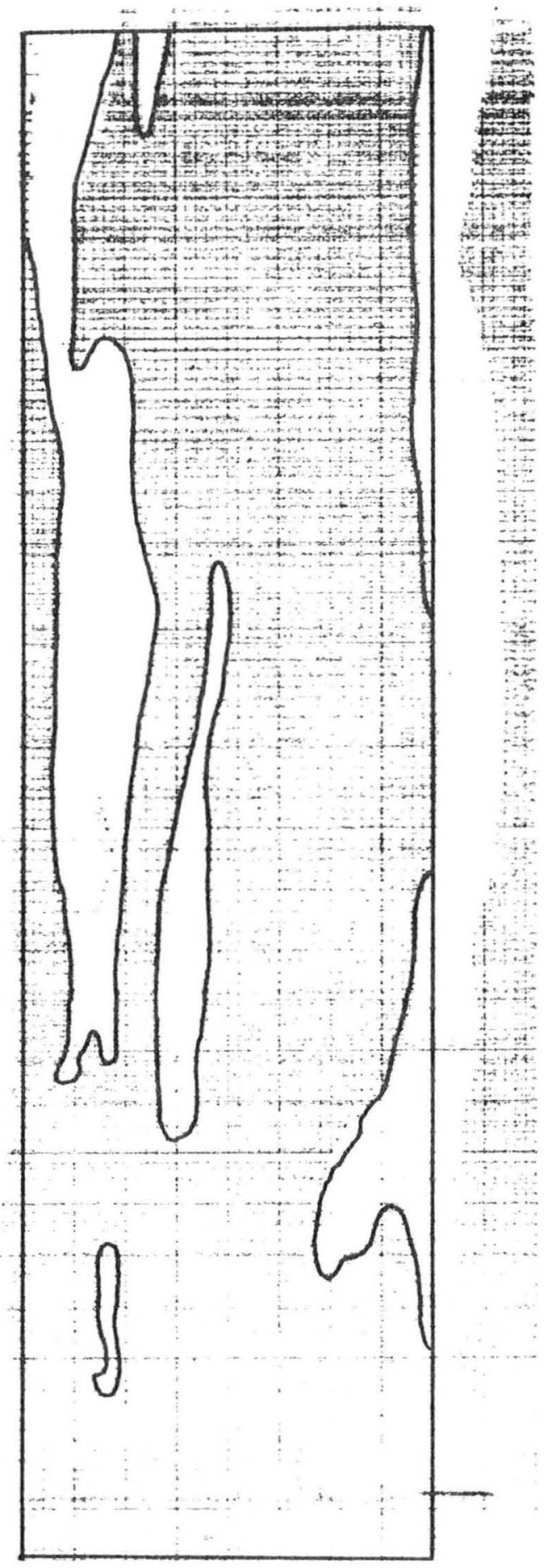

Figure 6. Through-transmission gated scan at 5 Megahertz - sample as used in Figures 1 to 3 ; regions of greatest attenuation shown outlined by ink. 


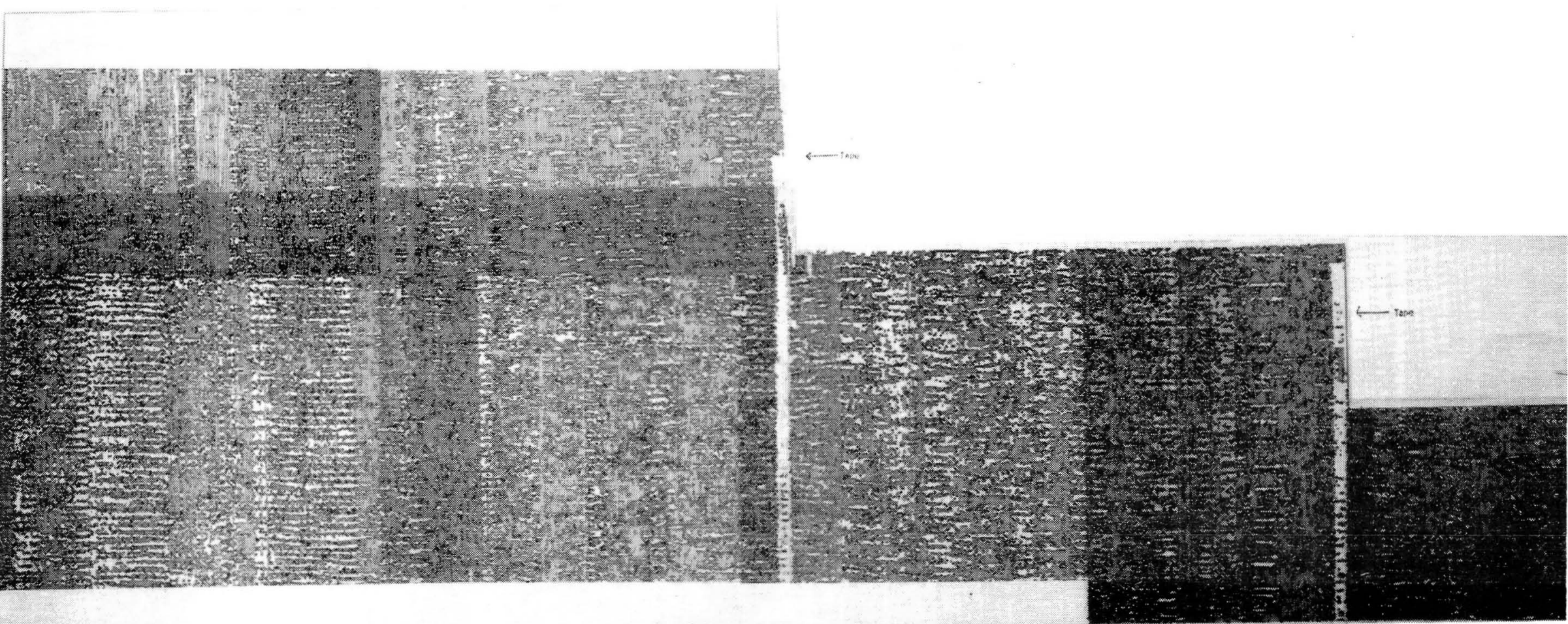

Figure 7. U1trasonic pulse-echo gated record at $1 \mathrm{MHz}$ for Panel 4A. Note that almost the entire panel contains regions of relatively high attenuation. These regions are parallel to the filaments in the panel. 

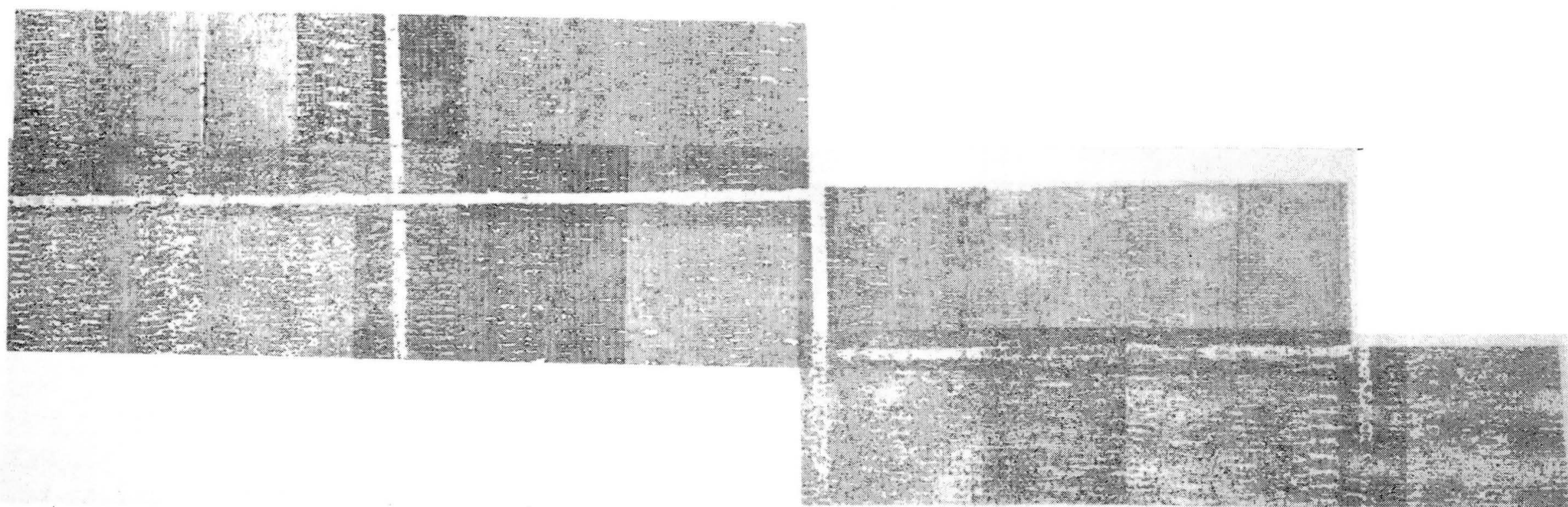

Figure 8. U1trasonic pulse-echo gated record at $1 \mathrm{MHz}$ for Panel $4 \mathrm{~B}$. Note that the panel is uniformly spotted with regions of high attenuation. These regions are parallel to the filament directions. 


\section{STATIC AND FATIGUE BEHAVIOR}

\subsection{Baseline Static Mechanical Data}

As described above in Table 1 of Section 1, using the specimens and procedures outlined in Appendix A, a static test program was conducted to establish the strengths and basic elastic moduli of the three laminated materials studied. A brief summary of the average mechanical properties of the three materials is presented in Table 4.

Comparison of the various materials indicates the following conclusions:

- Tensile and compression strengths of the epoxy matrix composites with Winding Pattern No. 1 are approximately $10 \%$ higher than those of Winding Pattern No. 2.

- Similarly, the tensile and compressive moduli of the epoxy matrix composites with Winding Pattern No. 1 are approximately $20 \%$ higher than those with Winding Pattern No. 2.

- There is no difference between the two patterns in the interlaminar shear strengths. The previous conclusions are consistent with the fact that the composite properties are fiber dominated, particularly with regard to the tensile and compression properties.

- The tensile and compressive strengths of the polyester matrix composites were slightly lower than those for Winding Pattern No. 1 of the epoxy matrix composites. The stiffnesses, however, were closer to those for Winding Pattern No. 2 .

- Comparing the two resin types for their common winding pattern, number 2, the static strengths of the polyester material are higher than the corresponding static strengths of the epoxy matrix materials. 
TABLE 4. SUMMARY OF BASELINE STATIC MECHANICAL PROPERTIES

OF THREE TFT COMPOSITE LAMINATES INVESTIGATED

\begin{tabular}{|c|c|c|c|c|c|c|c|}
\hline \multirow[b]{2}{*}{ Material ${ }^{a}$} & \multirow[b]{2}{*}{ Load Type } & \multirow{2}{*}{$\begin{array}{l}\text { Material } \\
\text { Condition }\end{array}$} & \multicolumn{2}{|c|}{ Strength } & \multicolumn{2}{|c|}{$\begin{array}{c}\text { Modulus } \\
\text { of Elasticity } \\
\end{array}$} & \multirow{2}{*}{$\begin{array}{c}\text { Poisson's } \\
\text { Ratio } \\
\end{array}$} \\
\hline & & & $\mathrm{MPa}$ & ksi & $\mathrm{GPa}$ & $10^{6}$ psi & \\
\hline \multirow[t]{6}{*}{$A$} & Tension & $\operatorname{RTD}^{b}$ & 464 & 67.2 & 31.9 & 4.63 & 0.284 \\
\hline & & wet $^{c}$ & 476 & 69.0 & 30.1 & 4.37 & 0.243 \\
\hline & Compression & RTD & 384 & 55.6 & 31.8 & 4.61 & 0.300 \\
\hline & & wet & 380 & 55.1 & 31.0 & 4.49 & -- \\
\hline & Int. Shear & RTD & 43.5 & 6.3 & -- & -- & -- \\
\hline & & wet & 74.5 & 10.8 & - & -- & - \\
\hline \multirow[t]{6}{*}{ B } & Tension & RTD & 473 & 59.9 & 26.6 & 3.85 & 0.312 \\
\hline & & wet & 386 & 56.0 & 23.7 & 3.44 & 0.331 \\
\hline & Compression & RTD & 345 & 48.6 & 25.3 & 3.67 & 0.378 \\
\hline & & wet & 358 & 51.9 & 28.0 & 4.06 & -- \\
\hline & Int. Shear & RTD & 49.7 & 7.2 & -- & -- & -- \\
\hline & & wet & 73.1 & 10.6 & -- & -- & -- \\
\hline \multirow[t]{6}{*}{ C } & Tension & RTD & 447 & 64.7 & 25.3 & 3.64 & 0.281 \\
\hline & & wet ${ }^{d}$ & 441 & 63.9 & 26.1 & 3.81 & 0.299 \\
\hline & Compression & RTD & 343 & 49.7 & 29.6 & 4.28 & 0.252 \\
\hline & & wet & 333 & 48.2 & 28.4 & 4.11 & 0.259 \\
\hline & Int. Shear & RTD & 72.4 & 10.5 & -- & -- & -- \\
\hline & & wet & 63.7 & 9.2 & -- & -- & -- \\
\hline
\end{tabular}

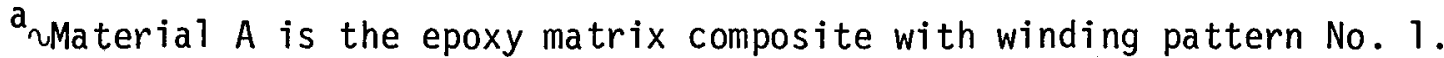
Material $B$ is the epoxy matrix composite with winding pattern No. 2 . Material $C$ is the polyester matrix composite, with winding pattern No. 2 .

b $\sim T=21^{\circ} \mathrm{C}\left(70^{\circ} \mathrm{F}\right), \mathrm{RH}=50 \%$.

$C^{C T}=49^{\circ} \mathrm{C}\left(120^{\circ} \mathrm{F}\right), \mathrm{RH}=98 \%$ for $500 \mathrm{hr}$.

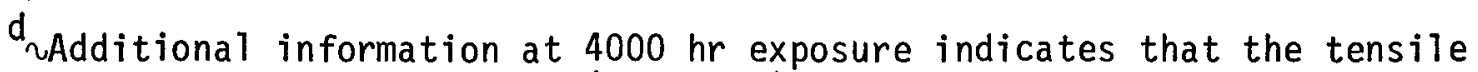
strength drops to $320 \mathrm{MPa}(46.4 \mathrm{ksi})$ although the modulus remains at $25.3 \mathrm{GPa}$ (3.65 msi) and Poisson's ratio stays at 0.274 . 
Additional conclusions with regard to the wet condition as opposed to the dry (RTD) condition are:

- There is little difference between wet and dry strengths and moduli for the epoxy matrix composite with Winding Pattern No. 1. There appears to be a mixed behavior for Winding Pattern No. 2, but overall there is not a significant difference between wet and dry

- Somewhat surprisingly, the interlaminar shear strengths for both winding patterns increased when wet over the dry values

- There was a significant decrease $(-25 \%)$ in the strengths of the polyester matrix composite which had been exposed to 4000 hours of $98 \% \mathrm{RH}$ from the dry strength properties. The high void content, as illustrated by the ultrasonic NDT examination, may have permitted a substantial moisture buildup to occur under the very long time exposures (greater than $4000 \mathrm{hr}$ ). This may also have resulted in the presence of greater strength-reducing mechanisms than if the sample was void free. The presence of cut edges on the sides of the sample could have contributed to the exposure of more of the interior material to moisture than would have occurred if the samples could have been tested in an "uncut" condition. However, the presence of voids, per se, does not necessarily imply the presence of wet tensile or compressive strength degradation. Moisture is absorbed through the surface to the interior of the material. Thus, the limiting or saturation moisture level of a material with high open voids may be reached sooner because of the greater surface area, but the level would not be quantitatively different.

The composite moduli were not affected by moisture since the moduli is a more fiber-dominated property than is the strength. 


\subsection{Effect of Moisture on Fatigue Life}

The individual fatigue data are presented in Appendix C. A summary of the tension-tension $(R=0) S-N$ curves for the epoxy matrix composites with Winding Pattern Nos. 1 and 2 are presented in Figs. 9 and 10, respectively. Both dry and wet behaviors were determined.

Some reduction in the wet fatigue strengths were indicated for the epoxy matrix composites with Winding Pattern No. 1. The wet fatigue strengths were not determined for all values of stress for the epoxy matrix material with Winding Pattern No.2, but the values obtained for $100 \mathrm{MPa}$ (14.5 ksi) stress range appeared to be part of the same $\mathrm{S}-\mathrm{N}$ curve.

\subsection{Effect of Mean Stress on Fatigue Life}

The majority of the fatigue data obtained as shown in Appendix $C$ were from tests performed at one stress level and as such do not lend themselves to an examination of the mean stress. However, some data are available from the epoxy matrix composites with Winding Pattern No. 1.

The fatigue lines are plotted in Fig. 11 for various values of the stress

range, i.e., $\left|S_{\max }-S_{\min }\right|$. The stress range can be calculated from Table 17 of Appendix $C$ by multiplying the peak stress per cycle (stress 7 evel) by the value $(1-R)$ where $R$ is the $R$ ratio. Thus for a peak stress of $82.8 \mathrm{MPa}$ $(12 \mathrm{ksi})$ at an $R$ ratio of -0.25 , we have the stress range $=1.25 \times 82.8=$ $103.5 \mathrm{MPa}$. The alternating component of this stress range is $0.5 \times 103.5=$ $51.75 \mathrm{MPa}$ and the mean stress would be $82.8-51.75=31.05 \mathrm{MPa}$. Figure 12 is a modified Goodman Plot of constant life curves obtained from Fig. 11 and the values of the alternating component of the stress range.

The curves portrayed in Fig. 12 are similar to those obtained for other common aerospace structural materials including metals, plastics, and composites. Thus, no particular problem would arise from the use of such curves in design with the TFT fiberglass/epoxy composites. 


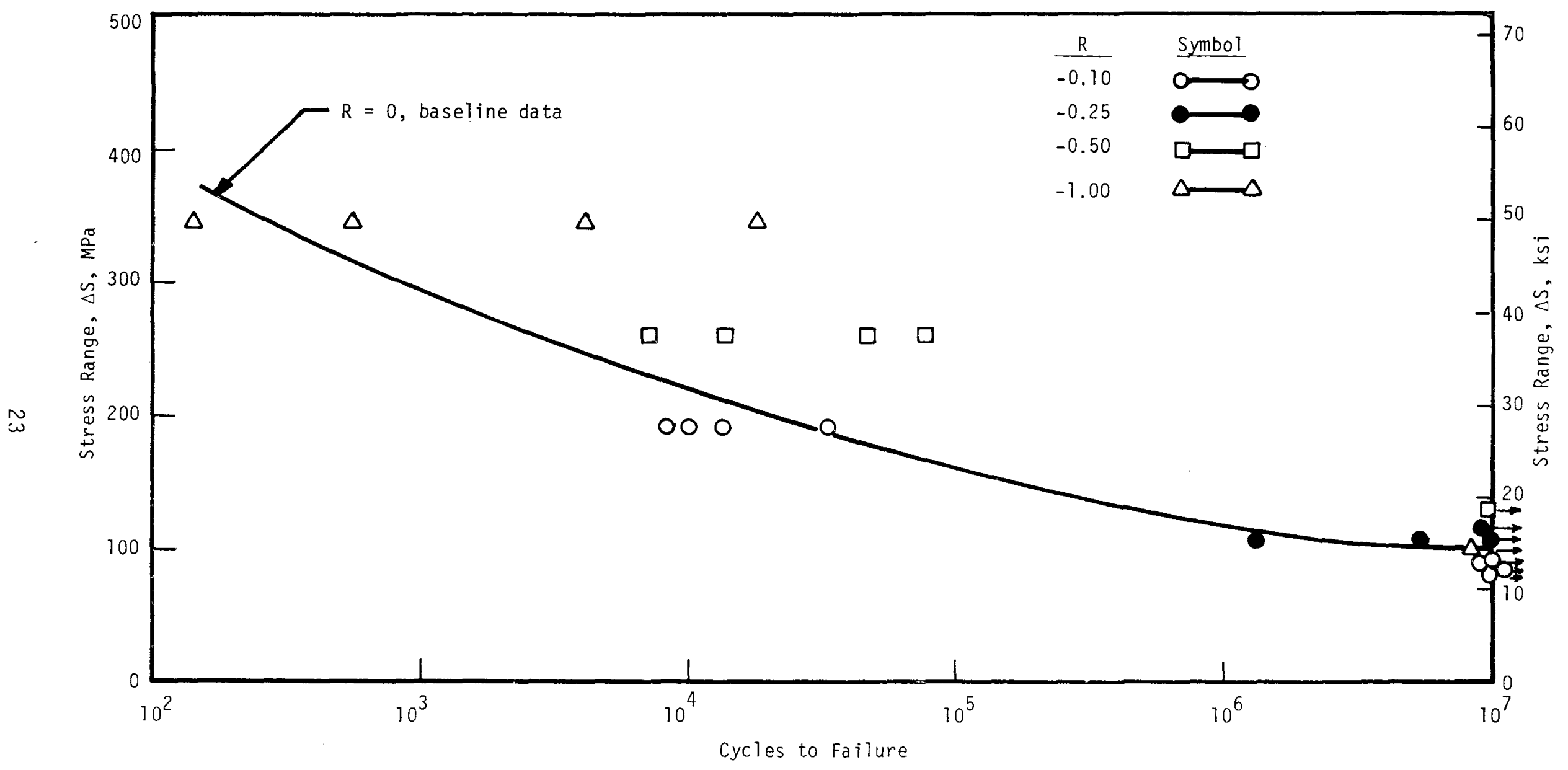

Figure 11. Effect of mean stress on the fatigue endurance for the epoxy matrix composite with winding pattern 1; a 11 tests performed at ambient conditions, $T=21^{\circ} \mathrm{C}\left(70^{\circ} \mathrm{F}\right), \mathrm{RH}=50 \%$. 


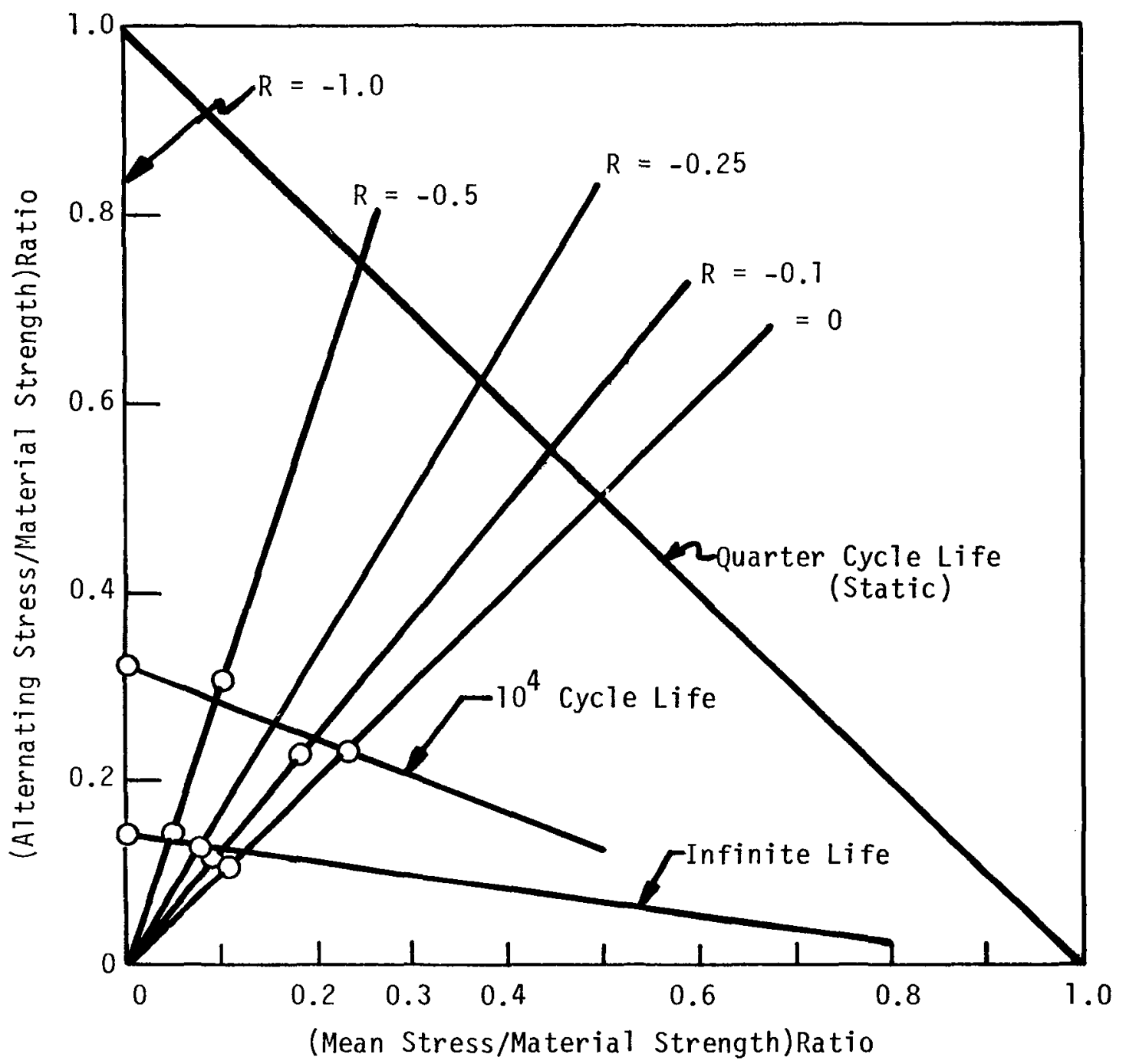

Figure 12. Modified Goodman diagram illustrating the effect of mean stress on the behavior of epoxy matrix composites with winding pattern No. 1 at $\mathrm{T}=21^{\circ} \mathrm{C}\left(70^{\circ} \mathrm{F}\right)$ and $\mathrm{RH}=50 \%$. [Material strength $=464 \mathrm{MPa}(67.2 \mathrm{ksi})$.] 


\section{SUMMARY OF RESULTS}

The following conclusions appear to be warranted by the results of the static and fatigue testing program:

- There does not appear to be a dramatic increase in tensile or compressive strength of the TFT composites compared with results obtained by other investigators. The lighter weight TFT ( $7 \mathrm{oz} / \mathrm{sq} \mathrm{yd}$ ) produces strengths approximately the same as those for the $36 \mathrm{oz} / \mathrm{sq}$ yd material used in the $150-\mathrm{ft}$ composite blade program by Kaman Aerospace.

- The effect of elevated temperature and moisture on the static tensile and compressive strengths of the epoxy matrix composites is not significant.

- There appears to be a significant loss of strength for polyester materials with long term exposure to moisture/elevated temperature.

- With respect to the elastic moduli, there is no effect of temperature and humidity, load direction, i.e., tension or compression, and type of resin.

- The fatigue results show an effect of moisture and temperature on the $\mathrm{S}-\mathrm{N}$ behavior of epoxy matrix $0^{\circ}-90^{\circ}$ composites (Winding Pattern No. 1 ). However, there did not appear to be any significant influence of moisture and temperature on the fatigue behavior of the $\left(0^{\circ} / 90^{\circ} / \pm 45^{\circ}\right)$ epoxy composites (Winding Pattern No. 2).

- The data obtained for the polyester matrix composite are all for $0^{\circ} / 90^{\circ} / \pm 45^{\circ}$ filament orientations and show a significant decrease in the ability to assume repeated stress at the same stress levels which were representative of runout for the corresponding epoxy matrix/fiberglas composites. 


\section{REFERENCES}

1. Anon., "Back to the Windmi11 to Generate Power," Business Week, May 11, 1974.

2. Anon., "Putting The Wind to Work," Engineering, Vol. 22, November 1968, pp. $760-1$.

3. F. Hirshfeld, "Wind Power," Mechanical Engineering, September 1977, pp. 20-28.

4. E. F. Lindsley, "Wind Power," Popular Science, July 1974, pp. 54-125.

5. C. E. Wise, "Bounty in the Breeze," Machine Design, August 11, 1977, pp. 20-26.

6. Anon., "Turning to the Wind," Machine Design, Apri1 9, 1981, pp. 156-161.

7. Anon., "Filament Winding Finds a Windfall in Search For New Energy Supplies," Modern Plastics, August 1977, pp. 54-55.

8. Anon., "Glass Fiber Composites Tilting at Windmills," in Update, Vol. 1, No. 9, p. 5 .

9. I.J.J. Cools, "Composite Rotor B1ades For An Experimental 300 kW Wind Turbine," Sampe Journa 1, May/June 1981, pp. 11-17.

10. H. W. Gewehr, "Design, Fabrication, Test and Evaluation of a Prototype 150-Foot Long Composite Wind Turbine Blade," NASA CR-159775, September 1981.

11. 0. Weingart, "Design, Evaluation and Fabrication of Low-Cost Composite Blades for Intermediate-Size Wind Turbines," NASA CR-165342, September 1981. 


\section{APPENDIX A}

TEST PROCEDURES FOR MECHANICAL TESTING OF TRANSVERSE FILAMENT TAPE FIBERGLASS/EPOXY AND POLYESTER MATRIX COMPOSITES

\section{A.1. MECHANICAL PROPERTIES, TEST SPECIMENS AND PROCEDURES}

The procedures for specimen fabrication and testing are discussed in this appendix.

\section{A.1.1 SPECIMEN BLANKS AND PRELIMINARY TESTS}

\section{A.1.1.1 Blanks for Specimens}

Panels were received at IITRI from the fabricators. The panels arrived at IITRI in the form of roughty cut squares approximately $91 \mathrm{~cm}$ (36 in.) on a side (see Table 5). The epoxy panels were then roughty quartered before machining to the shape shown in Fig. 14. The edges of the panels were not square and in most cases were not straight. The transverse filament tape carrier threads were visible in the surface and these threads were useful in establishing the $0^{\circ}$ direction of the transverse filaments themselves. Once an average or approximate $0^{\circ}$ direction had been established, this direction was marked on the surface of the quartered panel. The panel was then aligned on the surface of the cutting row (see Fig. 13) and the first straight edge on the panel was cut. All blanking started with this operation. Following this edge preparation, the $45.5 \mathrm{~cm}$ (18 in.) by $45.5 \mathrm{~cm}$ (18 in.) quarter panels were then cut into blanks, $2.54 \mathrm{~cm}$ (1.0 in.) wide by approximately $45.5 \mathrm{~cm}$ (18 in.) long (see Fig. 14). Blanking to the $2.54 \mathrm{~cm}(1.0 \mathrm{in.})$ strips was done before tabbing, for those specimens requiring tabs, rather than in the reverse order as is customary. This was done to avoid tab disbonding during the final specimen cutting operation.

Blanking of the polyester matrix panels was similar to that for the two epoxy matrix laminate types, except that the polyester/transverse filament tape laminates were nondestructively inspected by means of ultrasonic c-scan testing prior to blanking.

\section{A.1.1.2 Preliminary Tests}

A preliminary test program was conducted to determine the specimen adequacy, cutting directions $\left(0^{\circ}\right.$ or $\left.2^{\circ}\right)$ to the filament directions and equipment shakedown. Specimen dimensions were $2.54 \mathrm{~cm}$ (1 in.) wide by $27.94 \mathrm{~cm}$ (11 in.) long. 
TABLE 5. DESCRIPTION OF TFT/EPOXY COMPOSITE PANELS PROVIDED TO IITRI FOR FATIGUE TESTING

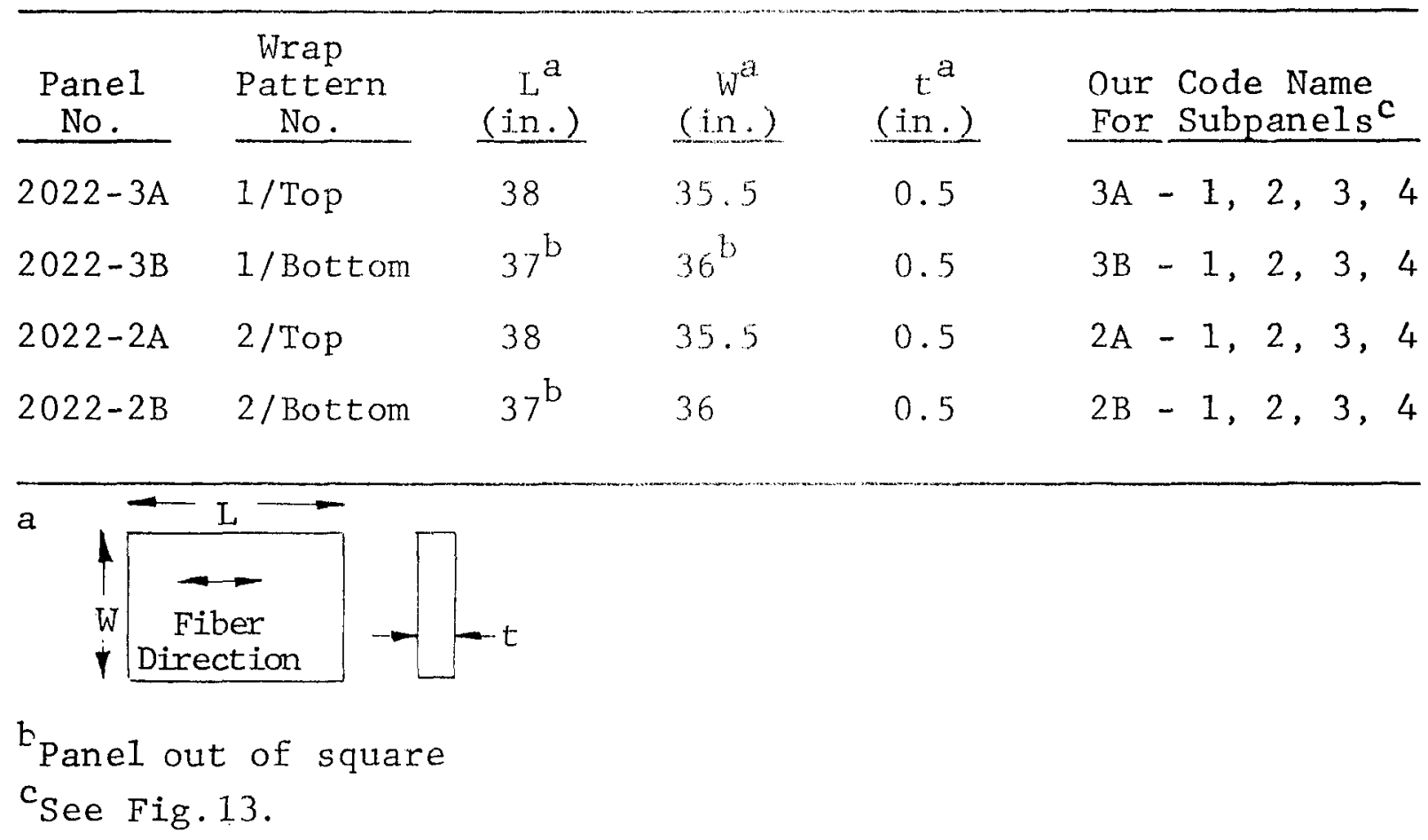


$91.4 \mathrm{~cm}$ (36 in.)

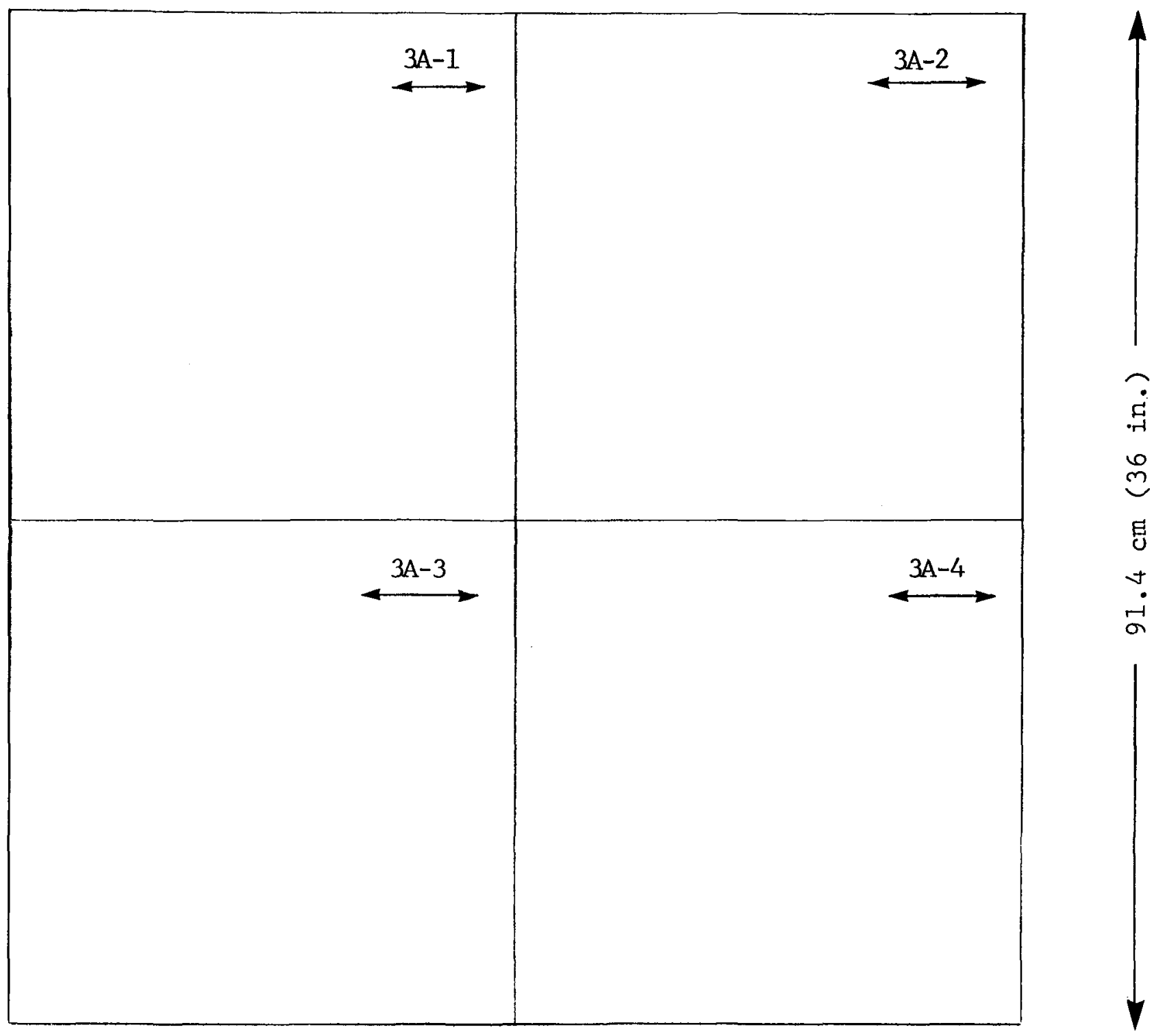

Figure 13. Typical example of panel partitioning prior to specimen blankirig operations (pane] No. 3A for epoxy matrix/TFT with winding pattern No. 1). The arrows beneath the subpanel numbers refer to the principal, or $0^{\circ}$, filament direction. 


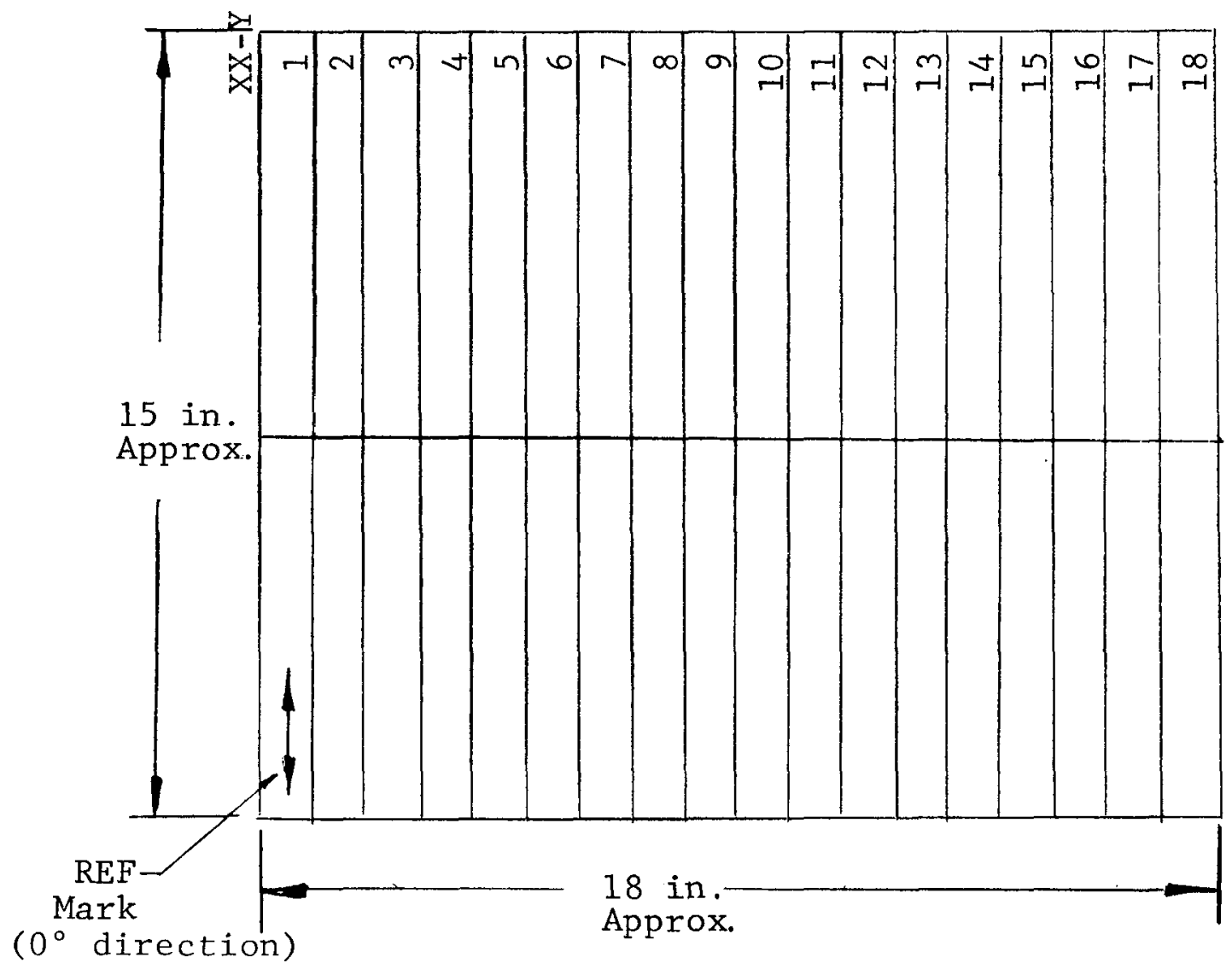

Figure 14. Sub-panel specimen blanking scheme. Each strip is 1 in. wide. All strips were cut parallel to reference mark (in $0^{\circ}$ direction). 
The tensile strengths for the epoxy matrix composites with winding angles 1 and 2 at $0^{\circ}$ and $2^{\circ}$ to the principal filament directions are shown in Table 6 .

Preliminary testing of the epoxy matrix composites was performed for the purpose of checking out the compression fixture. The results are shown in Table 7 .

An examination of the static tension and compression failure modes was made as wel1. Figures 15 and 16 illustrate failures for both of the epoxy matrix composites (Winding Pattern Nos. 1 and 2). Figure 15 shows compression failures. Note that the failures for the two patterns are dissimilar. It would appear that the material from plates prepared by sinding Pattern No. 1 show shear failure, with the failure zone occurring away from the ends and in the center of the material. Similarly, it appears that material from plates prepared by Winding Pattern No. 2 shows an end brooming mode that is located at the end of the specimen. Delamination is also present in the failure of Winding Pattern No. 2. As seen from Fig. 16, there was no apparent difference in the tension failures for the two materials.

Finally, preliminary compression fatigue tests were performed with two specimens at $0^{\circ}$ to the principal fiber direction and two specimens at $2^{\circ}$ to the principal fiber direction for the epoxy matrix composite with Winding Pattern No. 2, i.e., the $0^{\circ} / 90^{\circ} / \pm 45^{\circ}$ composites. The samples were 1 in. wide $x 11 \mathrm{in}$. long and were fully stabilized during repeated fully-reversed $(R=-1)$ loading. The results for a constant amplitude stress of $80 \%$ of the static compression strength are shown in Table 8. The test frequency was 1.0 Hertz. As a given specimen failed, it was replaced with a steel dummy sample and stroking was continued. Failed samples are shown in Fig. 17 of the epoxy matrix composites with Winding Pattern No. 2.

Both from failed specimen appearance and from the test results it appeared that there was no detectable difference in the results for the two fiber directions. 
TABLE 6. INDIVIDUAL SPECIMEN TENSILE STRENGTHS FOR EPOXY MATRIX/ TFT COMPOSITES WITH WINDING PATTERNS 1 AND 2 AT $0^{\circ}$ and $2^{\circ}$ TO THE PRINCIPAL FILAMENT DIRECTION

\begin{tabular}{ccccccc}
\hline $\begin{array}{c}\text { Composite } \\
\text { Winding } \\
\text { Pattern }\end{array}$ & $\begin{array}{c}\text { Specimen } \\
\text { Orientation } \\
\text { Relative to } \\
\text { Filament } \\
\text { Direction }\end{array}$ & & $\frac{\text { U1timate }}{\mathrm{KN}}$ & Load & & \multicolumn{2}{c}{$\begin{array}{c}\text { Tensile } \\
\text { Strength }\end{array}$} \\
\cline { 2 - 6 } & $0^{\circ}$ & 123.6 & 27.8 & 370 & 53.6 \\
& $0^{\circ}$ & 135.2 & 30.4 & 419 & 60.7 \\
& $2^{\circ}$ & 124.5 & 28.0 & 402 & 58.3 \\
& $2^{\circ}$ & 125.4 & 28.2 & 374 & 54.2 \\
1 & $0^{\circ}$ & 153.5 & 34.5 & 490 & 71.0 \\
& $2^{\circ}$ & 162.7 & 36.6 & 531 & 76.9 \\
\hline
\end{tabular}

a Sample broke in tab.

${ }^{b}$ Surface fibers appeared to be arranged substantially offaxis (they appeared to have a curved appearance). 
TABLE 7. INDIVIDUAL SPECIMEN COMPRESSIVE STRENGTHS FOR EPOXY MATRIX/TFT COMPOSITES WITH WINDING PATTERNS 1 AND 2

\begin{tabular}{|c|c|c|c|c|}
\hline $\begin{array}{l}\text { Winding } \\
\text { Pattern } \\
\end{array}$ & $\begin{array}{c}\text { Specimen } \\
\text { No. } \\
\end{array}$ & $\begin{array}{l}\text { Compressive } \\
\mathrm{MPa}\end{array}$ & $\frac{\text { Strength }}{\mathrm{ksi}}$ & $\begin{array}{c}\text { Test } \\
\text { Condition }\end{array}$ \\
\hline \multirow[t]{5}{*}{2} & $2 B 3-31$ & 370.5 & 53.7 & $\operatorname{RTD}^{\mathrm{a}}$ \\
\hline & $2 B 3-32$ & 348.5 & 50.5 & RTD \\
\hline & $2 B 3-33$ & 355.4 & 51.5 & RTD \\
\hline & $2 B 3-34$ & 357.4 & 51.8 & RTD \\
\hline & Average & 358.1 & 51.9 & RTD \\
\hline \multirow[t]{3}{*}{1} & $3 A 3-1 C$ & 407.8 & 59.1 & RTD \\
\hline & $3 A 3-2 C$ & 416.1 & 60.3 & RTD \\
\hline & Average & 411.9 & 59.7 & RTD \\
\hline
\end{tabular}

$a_{T}=21^{\circ} \mathrm{C}\left(70^{\circ} \mathrm{F}\right)$ and R.H. $=50 \%$. 


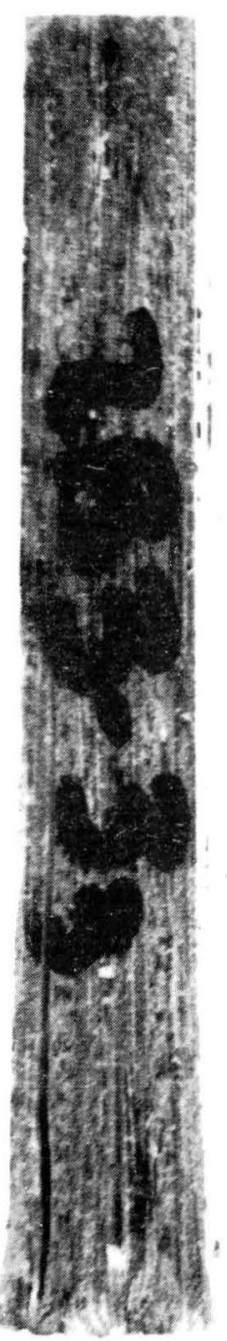

$2 B 3-33$

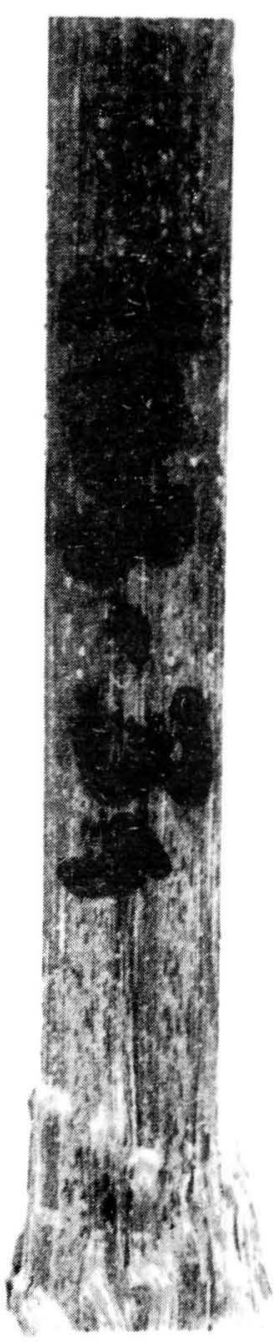

2 B3 -34

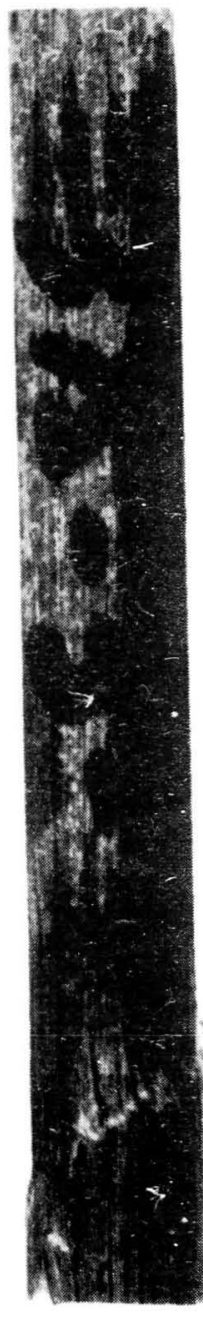

$3 A-3-2 C$

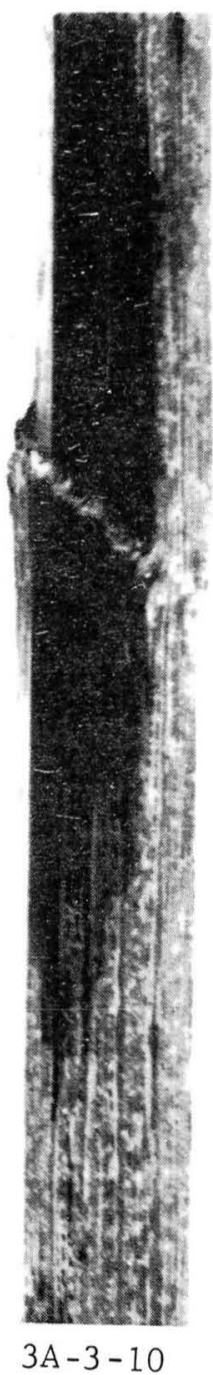

Winding Pattern 1

Figure 15. Fracture appearance of winding patterns 1 and 2 specimens subjected to static compression loading. 

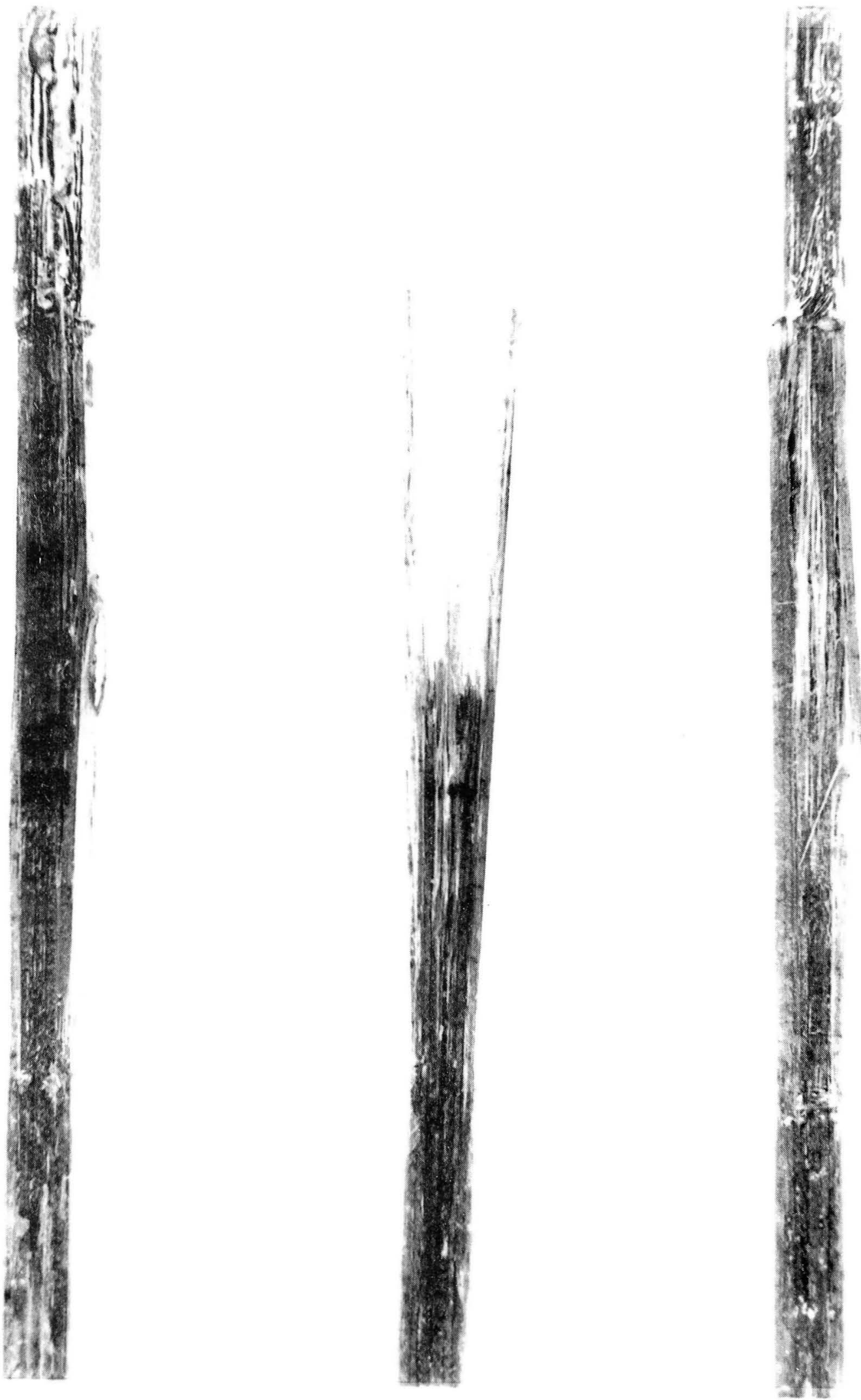

Winding Pattern No. 1

Winding Pattern No. 2 Winding Pattern No. 2

Figure 16. Typical fracture appearance of specimens subjected to static tension loading. 
TABLE 8. FATIGUE TEST RESULTS FOR TFT MATERIAL OF WINDING

PATTERN 2 ORIENTED AT $0^{\circ}$ AND $2^{\circ}$ TO THE PRINCIPAL

FILAMENT DIRECTION

\begin{tabular}{|c|c|c|c|c|}
\hline \multirow[t]{2}{*}{$\begin{array}{c}\text { Specimen } \\
\text { Orientation } \\
\text { Relative to } \\
\text { Filament } \\
\text { Direction, } \\
\text { deqrees } \\
\end{array}$} & \multirow{2}{*}{$\begin{array}{c}\text { Specimen } \\
\text { No. } \\
\end{array}$} & \multicolumn{2}{|c|}{$\begin{array}{c}\text { Alternating } \\
\text { Stress }\end{array}$} & \multirow{2}{*}{$\begin{array}{l}\text { Cycles to } \\
\text { Failure }\end{array}$} \\
\hline & & $\mathrm{MPa}$ & $\mathrm{ksi}$ & \\
\hline 0 & $2 B 3-1$ & \pm 246 & \pm 35.7 & 34 \\
\hline 0 & $2 A 4-121$ & \pm 270 & $\pm 39.2^{\mathrm{a}}$ & 27 \\
\hline 2 & $2 B 3-11$ & \pm 242 & \pm 35.1 & 21 \\
\hline 2 & $2 A 4-81$ & \pm 246 & \pm 35.7 & 39 \\
\hline
\end{tabular}

${ }^{a}$ Smaller cross-sectional area than other specimens but load held at $\pm 88.96 \mathrm{KN}$ ( $\pm 20 \mathrm{kips})$.

Tested at $R=-1, \phi=1$ Hertz, $T=25^{\circ} \mathrm{C}\left(78^{\circ} \mathrm{F}\right)$, $\mathrm{RH}=50 \%$. 

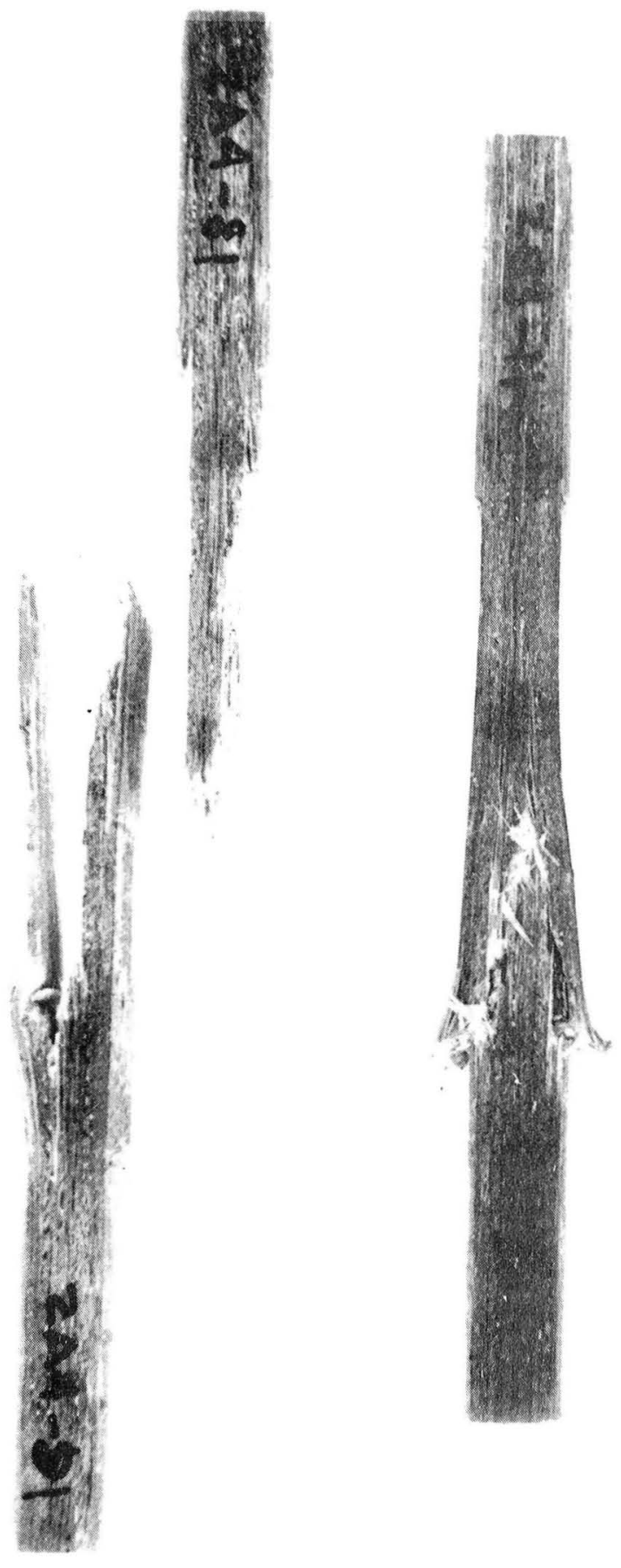

2A4-91
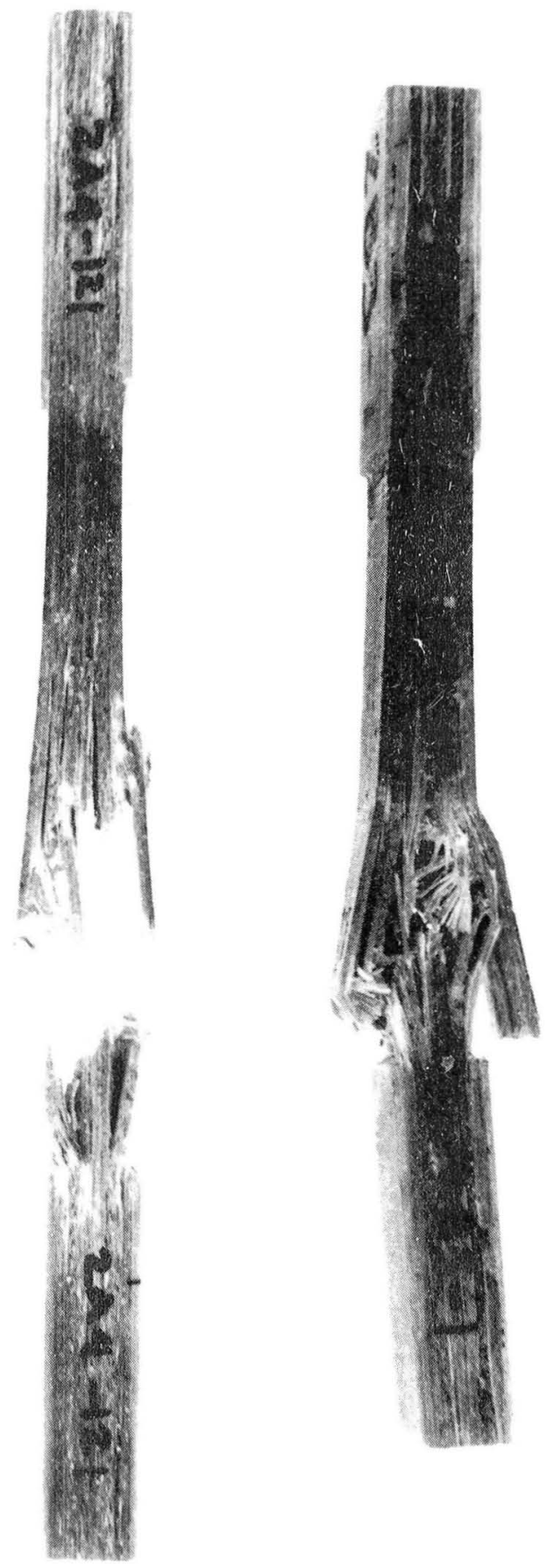

2B3-11

2A4-12 1

2 B3 - 1

$0.7 \mathrm{X}$

Figure 17. Fracture appearance of samples of winding pattern 2 subjected to fully-reversed loading. 


\section{A.1.2 TENSION TESTS}

After blanking operations were completed, preparation of the individual tension samples was initiated. The tension specimen shown in Fig。18 was developed. It is similar to the conventional IITRI tension coupon for advanced composite materials. The doubler tabs on both sides and each end of the sample are bonded by means of adhesive to the rectangular blank prepared as described above. The adhesive chosen for bonding the tabs to both the epoxy matrix and the polyester matrix composites was Hysol 100.

Specimens were conditioned, as will be described later, and were then instrumented with three electrical resistance foil strain gages located at the center of the 6 in. gage section shown in Fig. 18.

Load was increased in approximately 4.448 or $8.896 \mathrm{KN}$ ( 1 to 2 kips) increments to failure. After each increment of load, readings were taken. The stress versus strain diagrams were plotted and the modulus of elasticity, Poisson's ratio, and ultimate tensile strength were obtained from the stressstrain diagrams.

Typical failed room temperature dry and wet samples are shown in Figs. 19 and 20 for epoxy matrix/TFT fiberglass composites with winding Pattern Nos. 1 and 2 , respectively.

\section{A.1.3 COMPRESSION TESTS}

Static compression tests were conducted using the specimen shown in Fig, 21 in the static compression fixture shown in Fig. 22. A window in the center of one of the two sides of the compression fixture permitted the use of electrical resistance foil strain gages. The load increments and methods of calculating elastic modulus, Poisson's ratio, and ultimate strength were similar to those used for tensile mechanical properties.

Typical static compression failure modes are shown in Fig. 23. A11 failures were a combination of transverse fracture and brooming.

\section{A.1.4 INTERLAMINAR SHEAR TESTS}

Interlaminar shear tests were conducted on samples with transverse filament tape (TFT) fiberglass reinforced epoxy and polyester matrix composites. The short beam shear specimen shape and test methods are shown schematically 


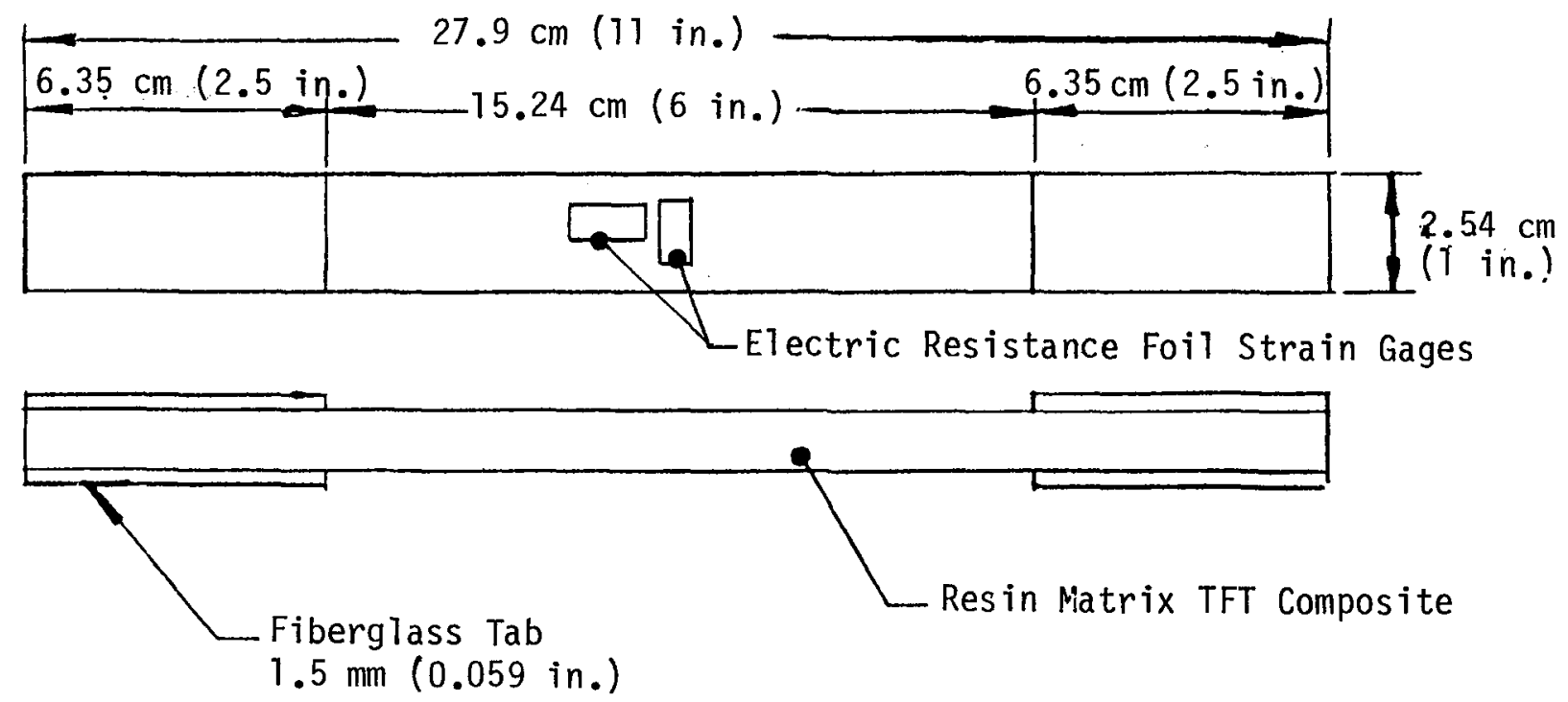

Figure 18. Static and fatigue coupon for both epoxy matrix and polyester matrix/TFT composites. 


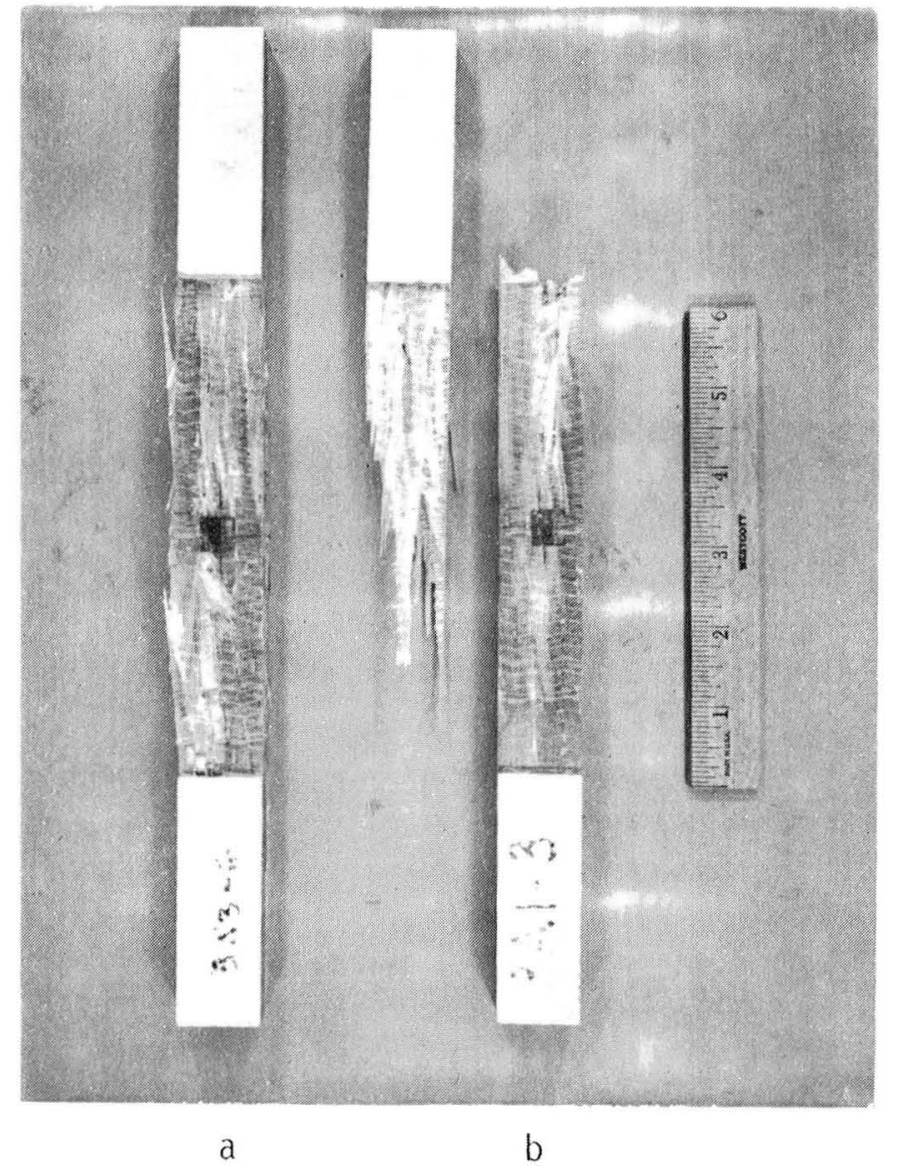

Figure 19. Top view of fractured TFT/epoxy matrix static tension specimens Winding Pattern No. 1. a) RTD; b) wet. 


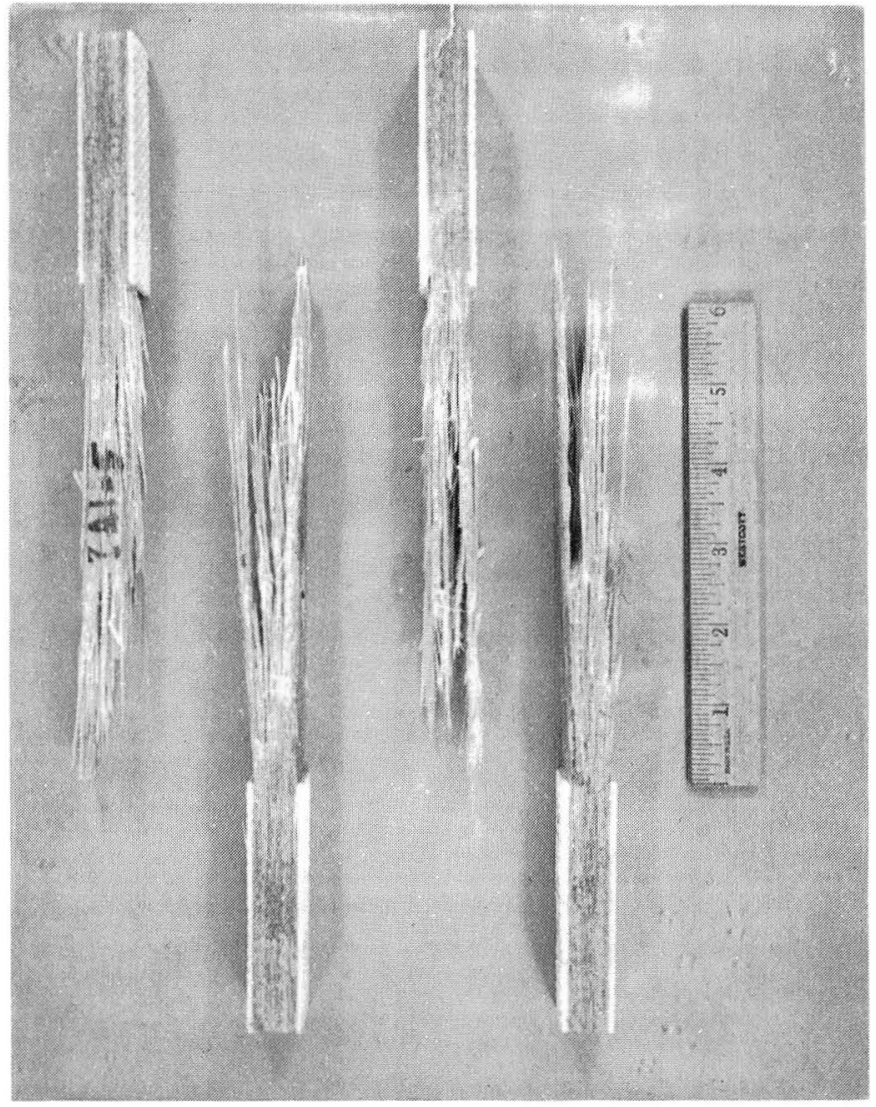

a

b

Figure 20. Side view of fractured TFT/epoxy matrix, static tension on specimens with Winding Pattern No. 2. a) RTD; b) wet. 

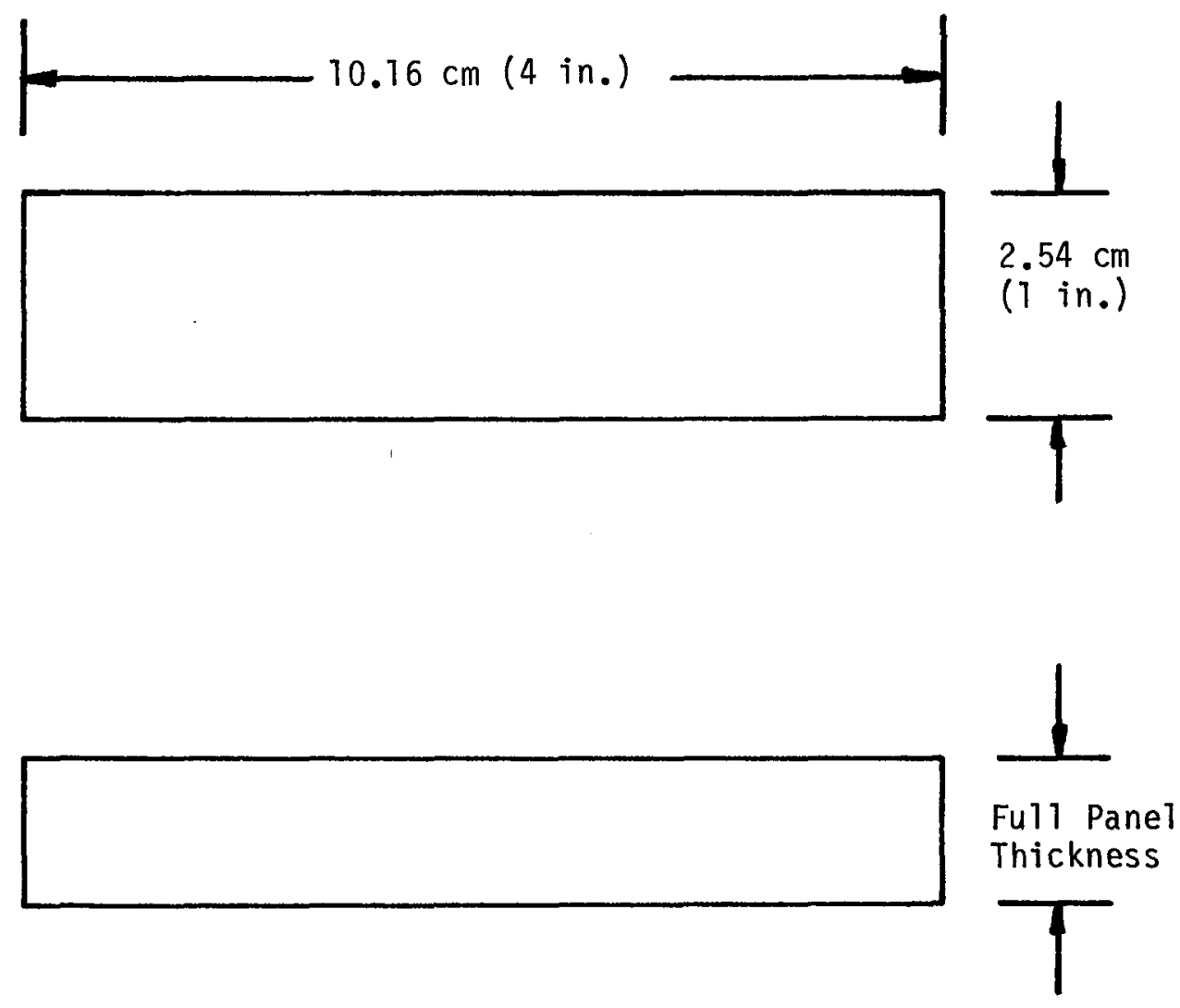

Figure 21. Static compression specimens. 


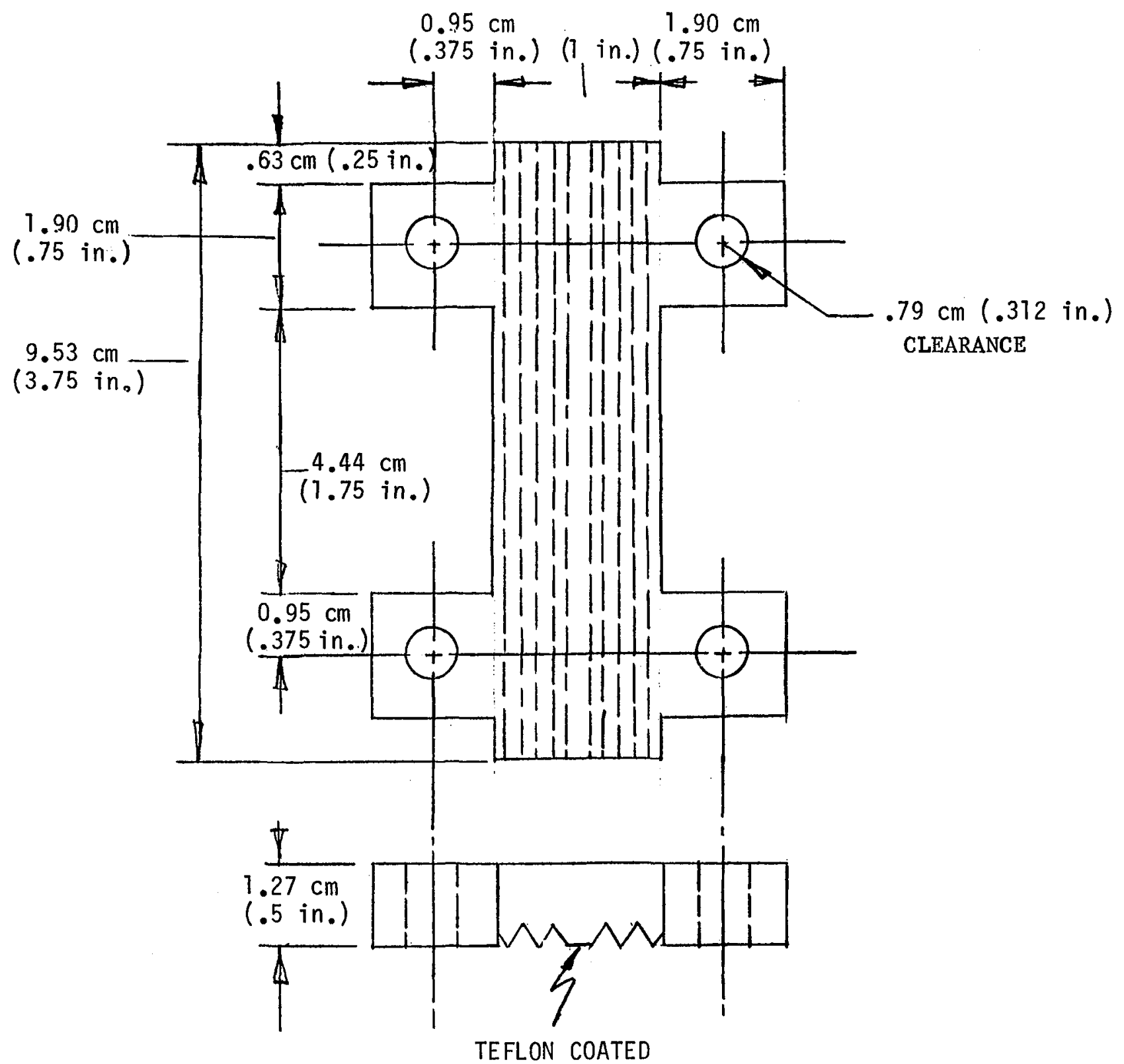

Figure 22. Stainless steel static compression fixture (two sides required). 

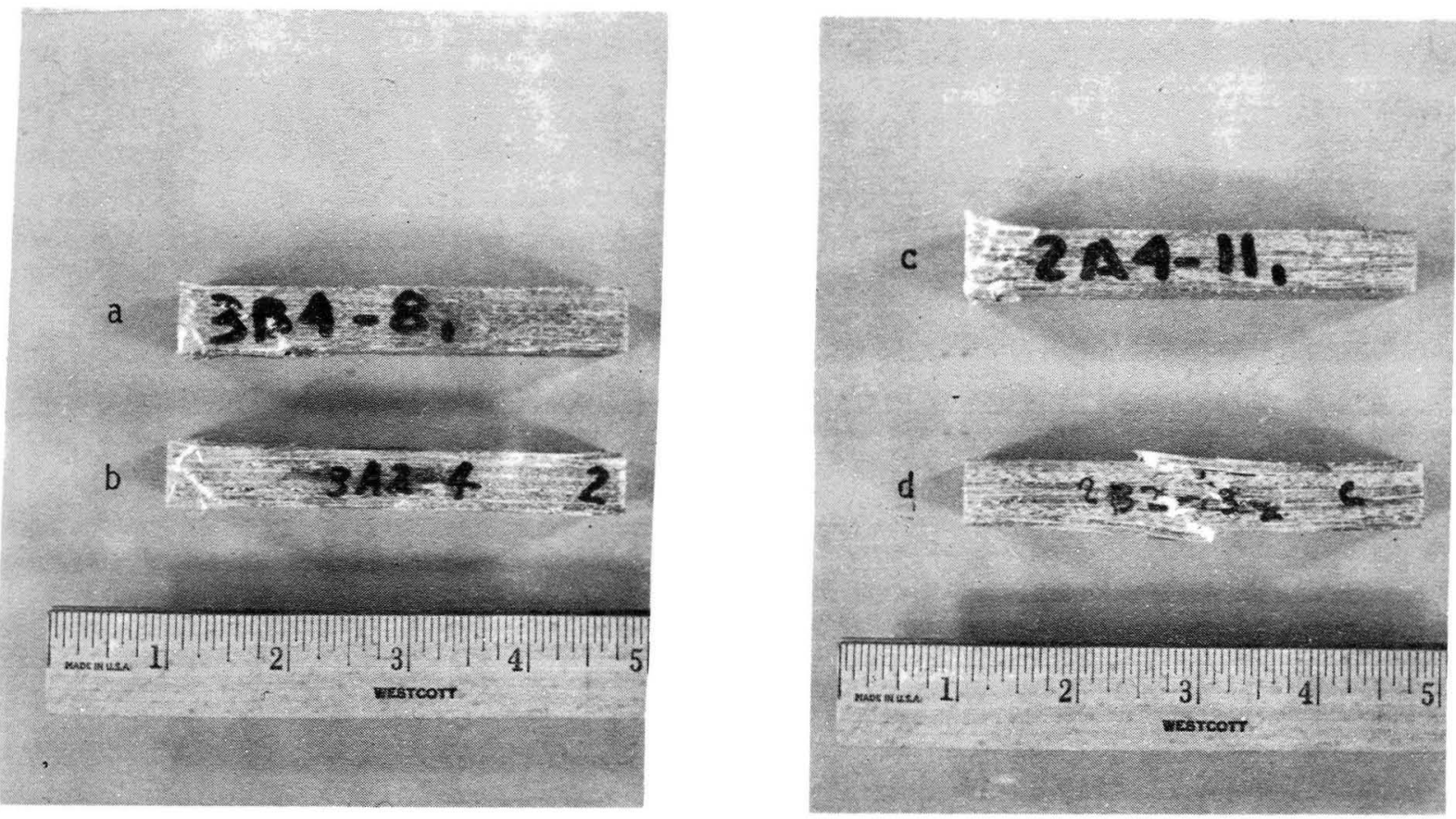

Figure 23. Typical failed compression samples for epoxy matrix/TFT fiberglass with Winding Pattern Nos. 1 and 2.

a) Winding Pattern No. 1 , tested RTD; b) Winding Pattern No. 1 tested wet; c) Winding Pattern No. 2, tested RTD;

d) Winding Pattern No. 2, tested wet. 
in Fig. 24. Loads were increased steadily to failure. The interlaminar shear strength was calculated as follows:

$$
\text { Shear Strength }=\mathrm{T}=1.5 \mathrm{P} / \mathrm{wt}
$$

where $P=$ load

$w=$ specimen width

$t=$ specimen thickness.

Typical failed samples are shown in Fig. 25. 

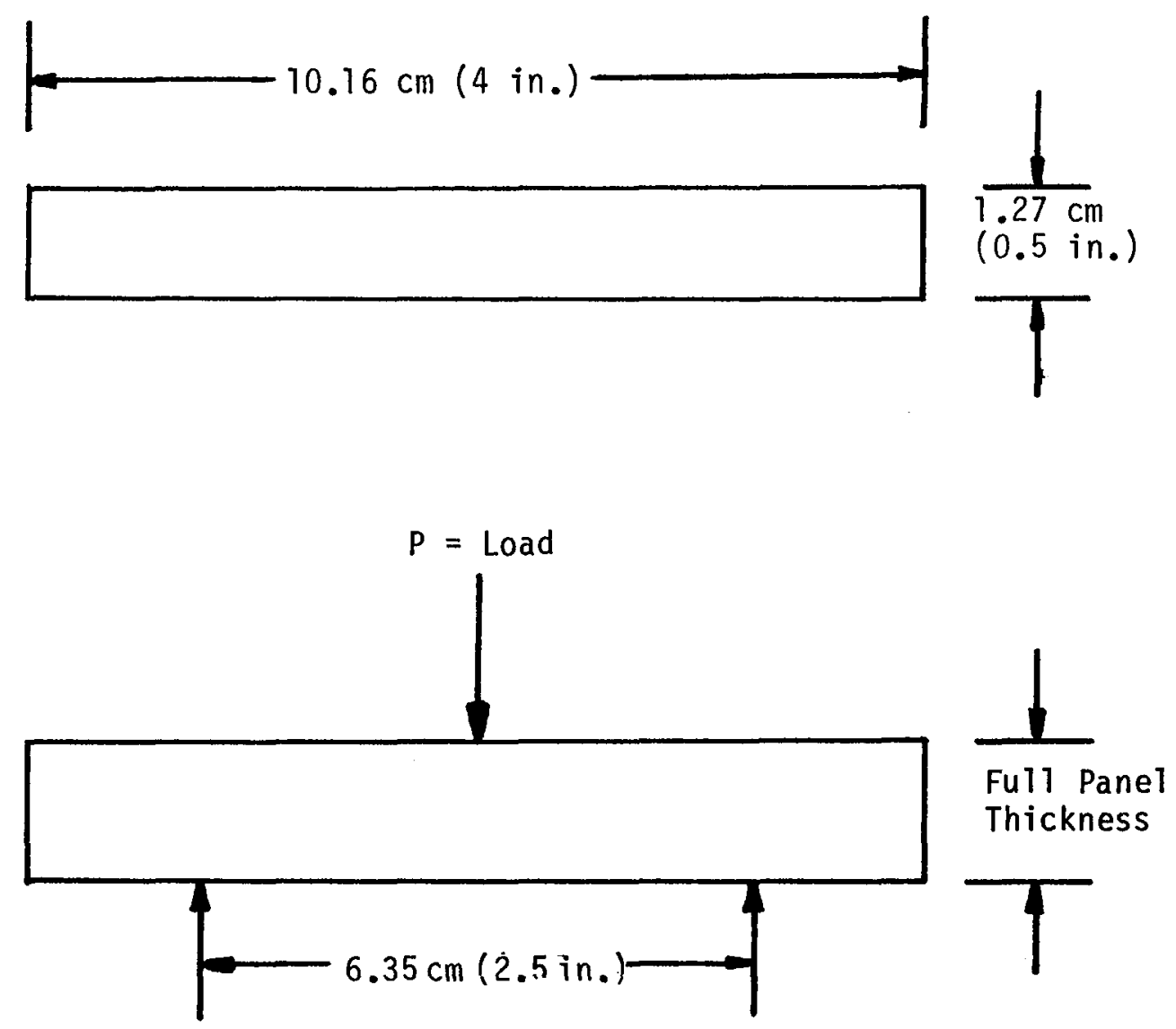

Figure 24. Schematic of the interlaminar shear specimen and loading procedures. 


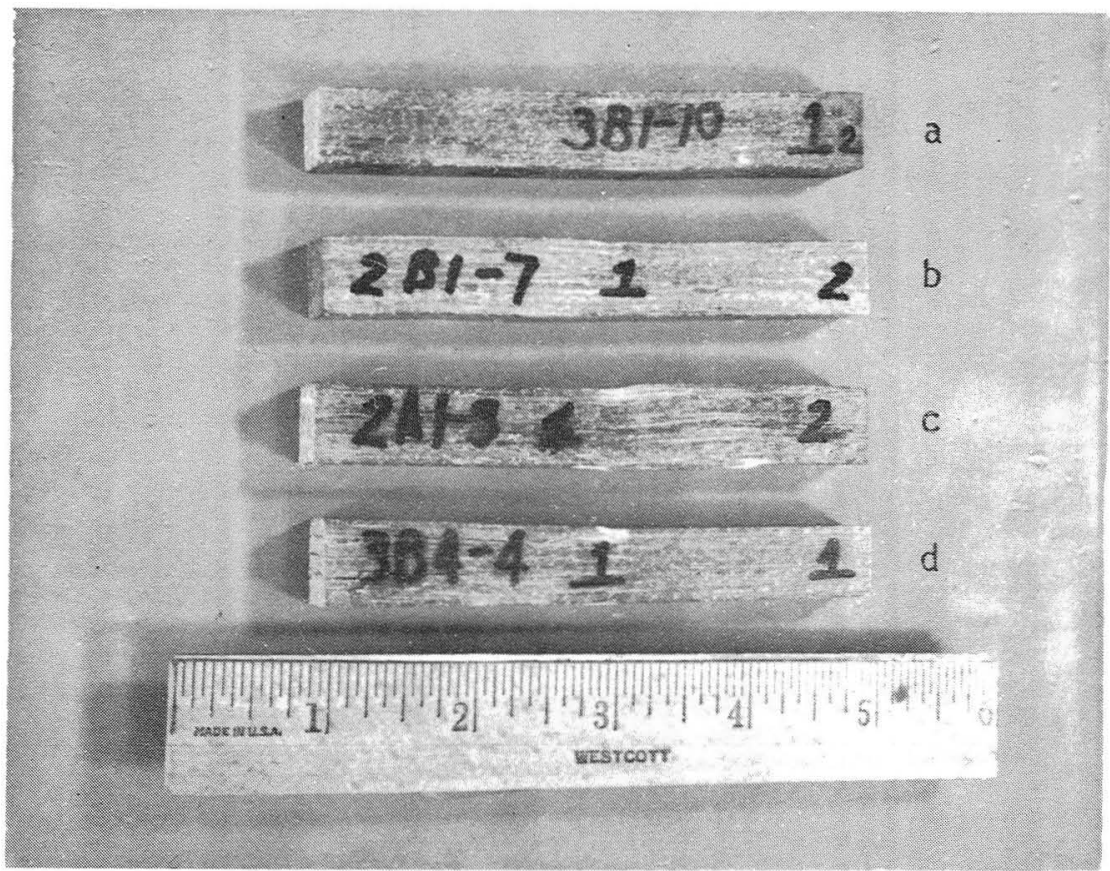

Figure 25. Typical side views of interlaminar shear failures of epoxy matrix/TFT composites with Winding Pattern Nos. 1 and 2. a) Winding Pattern No. 1 tested wet; b) Winding Pattern No. 2 tested wet; c) Winding Pattern No. 2 tested dry; d) Winding Pattern No. 1 tested dry. 


\section{A.2. ENVIRONMENTAL CONDITIONING BEFORE AND DURING TESTS}

The procedures and conditions for establishing and maintaining ambient and wet environments before testing and during the tests are described in this section.

\section{A.2.1. DRY AMBIENT CONDITIONS (RTD)}

The room-temperature dry (RTD) designation refers to samples which have been dried to a constant weight in an oven at $120^{\circ} \mathrm{F}$ ( 6 hours) and held in a dessicator in the test $7 a b$.thereafter until ready for testing. Both static (single cycle) and fatigue tests were conducted in the RTD condition. The fatigue testing was accomplished at 30 hertz and was performed using a fan to prevent heat buildup. The temperature of the specimen never exceeded $78^{\circ} \mathrm{F}$.

\section{A.2.2. WET CONDITIONS}

A11 samples were prepared as above to the dry condition and were then held in an oven at $120^{\circ} \mathrm{F}$ in a covered tray, suspended but not immersed, over water. The period of time used was 500 hours, but one series of specimens was subjected to 4000 hours of exposure. The weight gain after 500 hours was negligible as determined by preliminary experiments, while the weight gain after 4000 hours of exposure was approximately $2 \%$ by weight.

Testing statically was accomplished using a Missimers oven with a pan of water at the bottom of the unit throughout testing. The wet fatigue tests were conducted in a special environmental chamber in a chain of four specimens tested simultaneousiy (see Fig. 26). The fixture has been described elsewhere by Hofer ${ }^{\text {a }}$ and will not be repeated here.

\footnotetext{
${ }^{a}$ K. E. Hofer and J. Jollay, "Growth of Four Flaw Types in Graphite/Epoxy Due to Fully Reversed Loading," in "Fibrous Composites in Structural Design," Ed. by E. Leroe, et al, Plenum Press, 1980, pp. 837-845; K. E. Hofer and G. Waring, "Fatigue and Residual Strength and Flaw Growth of Graphite/Epoxy Composites Under Simulated Aerospace Environment," in Proc. 1978 Int. Conf. on Composite Materials, Published by Met. Soc. AIME, 1978, pp. 259-276; and D. Y. Konishi, P. Parmeley and K. E. Hofer, "On the Accelerated Testing of Graphite/Epoxy Coupons," in Proc. 1978 Int. Conf. on Composite Materials, Published by Met. Soc. AIME, 1978, pp. 1604-1619.
} 


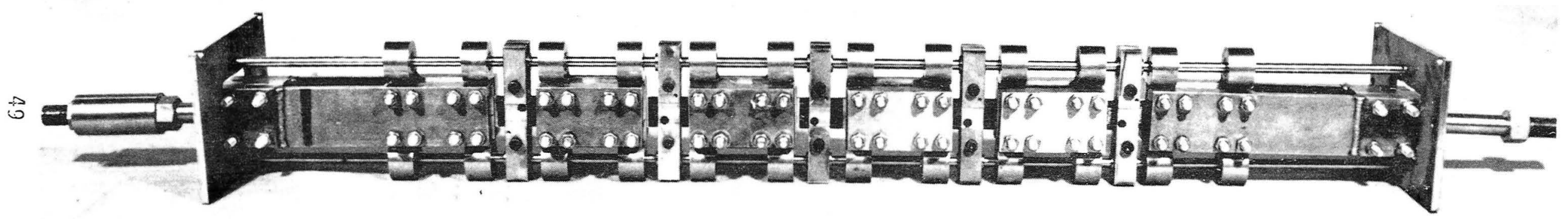

Figure 26. Multi-specimen loading chain for fatigue testing TFT fiberglass composite wind turbine blade material. 
The compression fatigue testing ( $R=-1.0,-0.2$, etc.) required that the individual samples be stabilized against buckling. The four-specimen testing fixture was examined to see how it might be modified for thick composite samples to prevent that buckling. The fixture was originally designed for specimens which were $1.07 \mathrm{~cm}(0.42 \mathrm{in.})$ thinner than the panels tested during this investigation.

The problem was solved by adding inserts to the conventional compression fatigue stabilizing fixture shown in Fig. 27. These inserts are shown in Fig. 28, and fit around the Thomson Ball Bushings. The stabilizing bars were fitted around the thick samples, were restrained to move parallel to the axis of compressive stroking, and were centered on the centerline of the actuator motion. In addition to these specimens anti-buckling measures, additional support for the two end yokes in the chain were required. This modification was necessary to prevent buckling of the overall chain. Figure 29 shows this modification. Figure 30 shows the test stand with five-specimen chain for fatigue loading. 


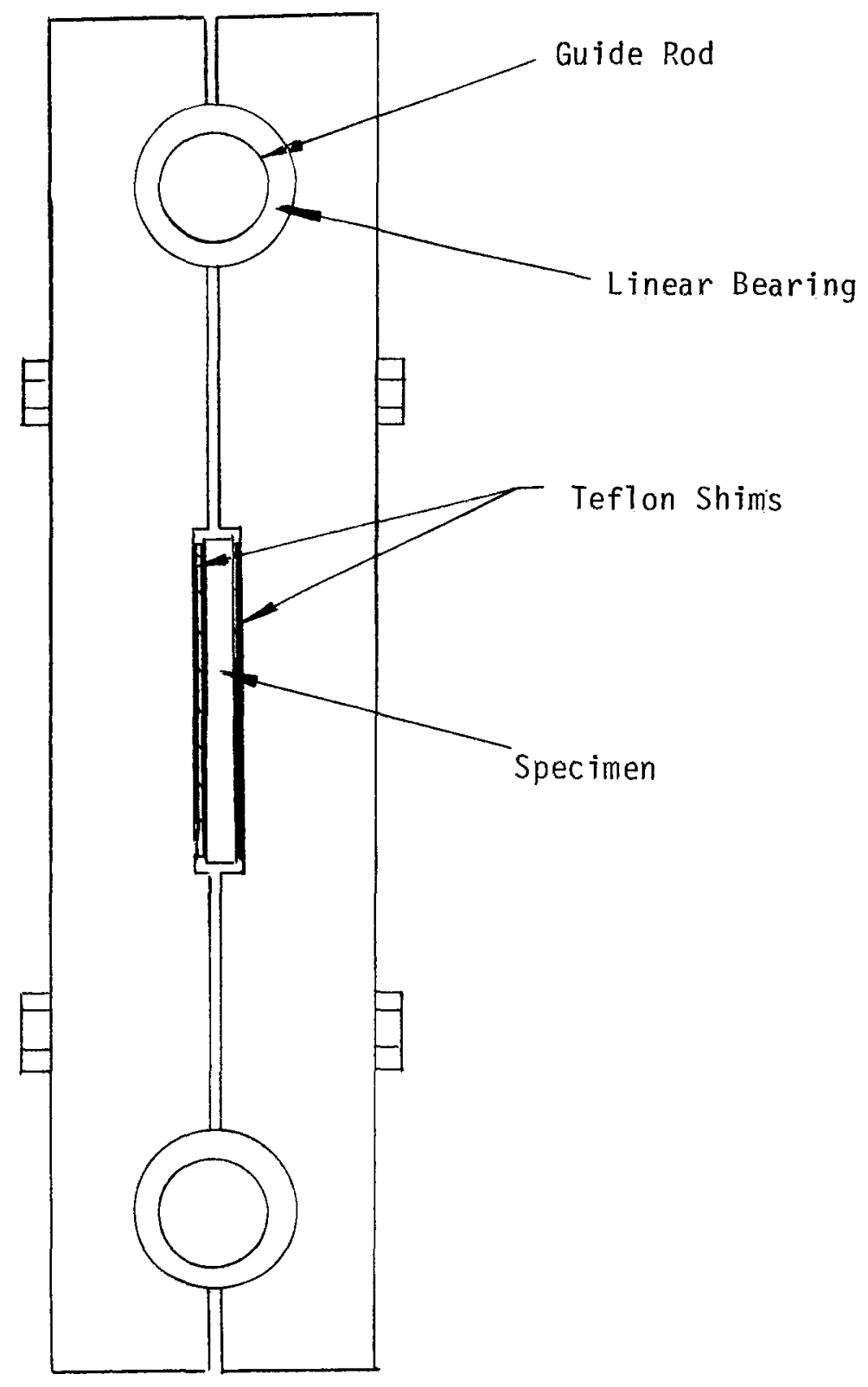

Figure 27. Schematic of compression fatigue anti-buckling stabilization bars. 


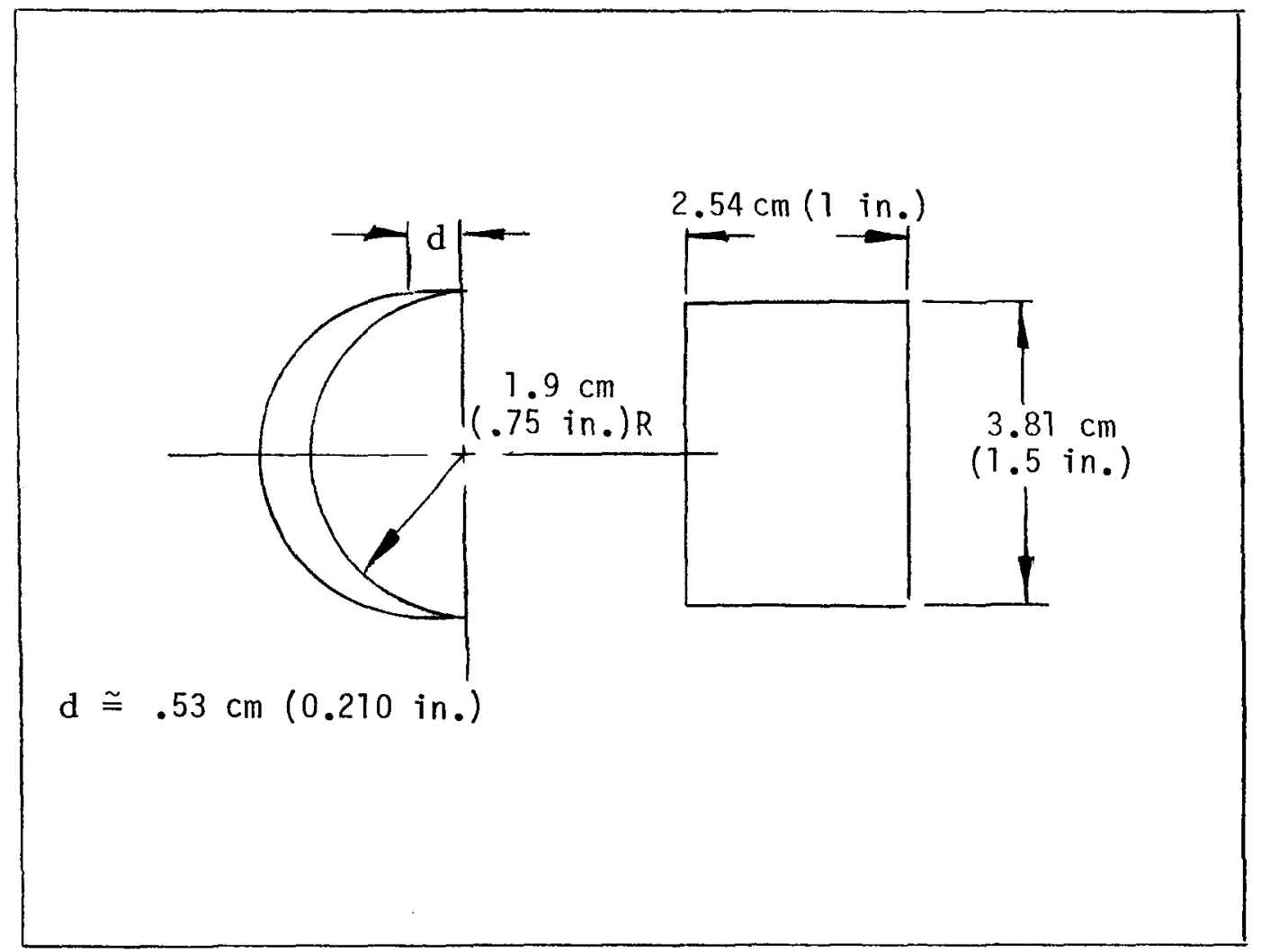

Figure 28. Spacer segments for compression fatigue stabilizing bars. 


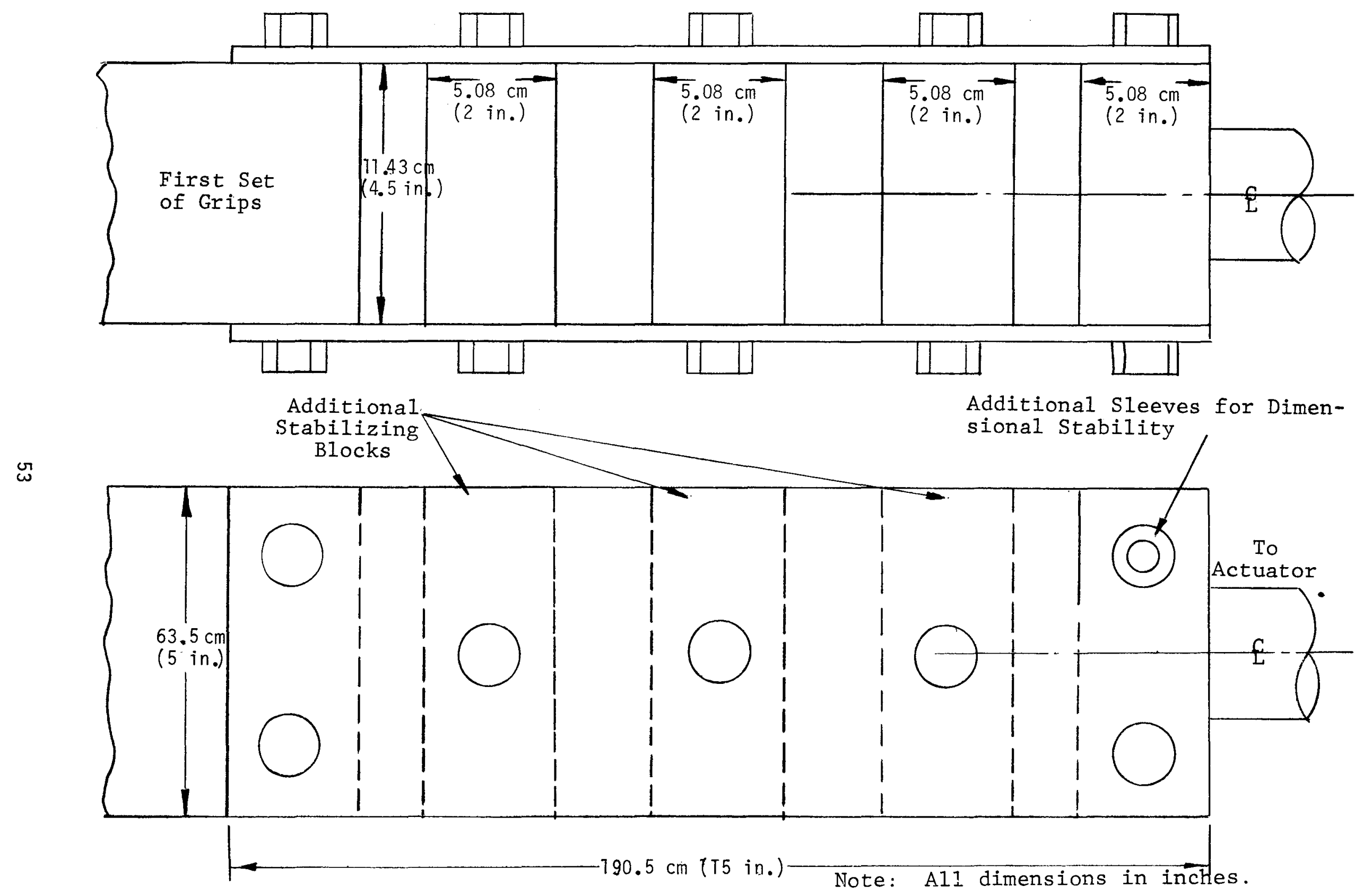

Figuare 29. Schematic of modification of multi-specimen chain load transmitting yoke required to prevent buckling. 


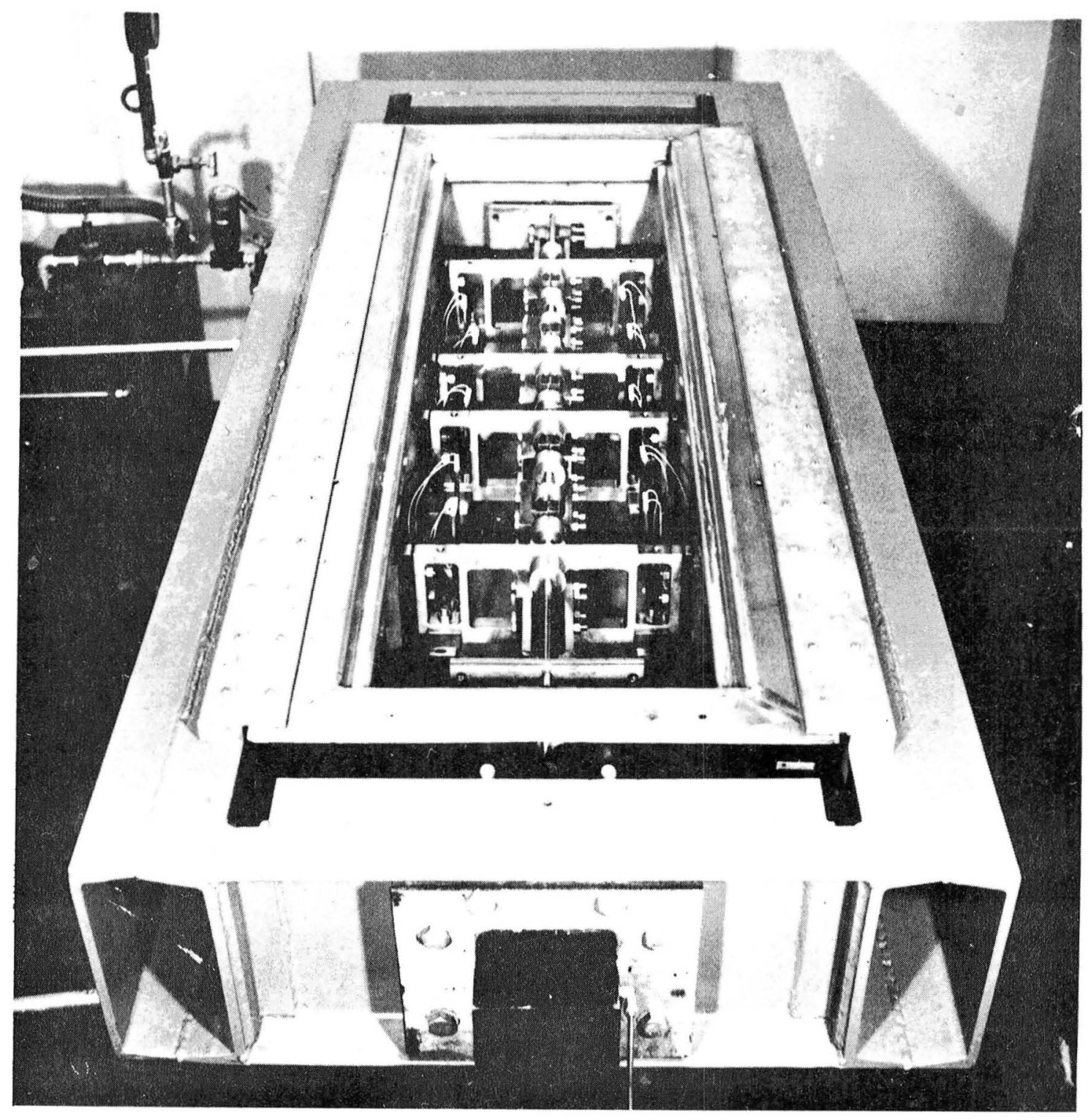

Figure 30. Test stand with five-specimen chain for spectrum fatigue loading 


\section{APPENDIX B \\ STATIC MECHANICAL PROPERTIES OF EPOXY MATRIX AND POLYESTER MATRIX TFT COMPOSITES}

This appendix presents individual test specimen results for the studies described in this report. Figures 37 to 42 are the tensile and compressive stress-strain curves in ambient $\left[\mathrm{T}=27^{\circ} \mathrm{C}\left(70^{\circ} \mathrm{F}\right), \mathrm{RH}=50 \%\right]$ and hot-humid $\left[\mathrm{T}=49^{\circ} \mathrm{C}\left(120^{\circ} \mathrm{F}\right), \mathrm{RH}=98 \%\right]$ conditions. Tables 9 through 16 present a summary of the tensile strengths, elastic moduli, and Poisson's ratios from these curves.

An examination of the failed specimens was made. The results indicated are discussed below:

In tension, the epoxy matrix composites differed substantially based on structure of the reinforcement. Pattern No. 1 laminates showed practically no difference between the dry and wet fracture modes. Pattern No. 2 appears as brooming type failures (many long filament bundles with a large amount of individual fiber spraying) for the dry material. Wet, the failures appeared to be local failures of the fiber bundles with few individual fibers showing up. The polyester tension fracture modes were similar to those of epoxy matrix pattern No. 2. The dry tension failure mode exhibited multiple bundle fractures with longitudinal "intra-bundle" fractures as well as separation of bundles. The wet and supersaturated tension fracture modes appeared as multiple bundle fractures with separation.

The static compression failure modes for both epoxy matrix patterns 1 and 2 were by end brooming for both dry and wet states, with one specimen of pattern No. 2 failing the center of the gage section. The polyester static compression specimen exhibited different failure modes wet and dry. The dry failures were by brooming while the majority of the wet failures were in the center of the gage section by direct compression.

The static interlaminar shear failure modes for epoxy matrix pattern No. 1 appeared as multiple interlaminar separations with wide gaps dry and a single interlaminar fracture wet. Pattern No. 2 failures showed a substantial hinge like appearance viewed from the side for both wet and dry samples. The polyester material exhibited multiple interlaminar separations with a slight crushing directly under the central load (this was never a source of the terminal failure). 


\section{TABLE 9. TENSILE PROPERTIES OF EPOXY MATRIX \\ COMPOSITES WITH WINDING PATTERN NO. 1}

\begin{tabular}{|c|c|c|c|c|c|c|}
\hline \multirow{2}{*}{$\begin{array}{c}\text { Specimen } \\
\text { Number } \\
\end{array}$} & \multicolumn{2}{|c|}{ Tensile Strength } & \multicolumn{2}{|c|}{ Modulus of Elasticity } & \multirow{2}{*}{$\begin{array}{c}\text { Poisson's } \\
\text { Ratio } \\
\end{array}$} & \multirow{2}{*}{$\begin{array}{c}\text { Test } \\
\text { Condition } \\
\end{array}$} \\
\hline & Megapascals & $\mathrm{ks} i$ & Gigapascals & $10^{6} \mathrm{psi}$ & & \\
\hline $\begin{array}{l}3 B 4-7 \\
3 A 3-6 \\
3 A 1-13 \\
3 B 2-5 \\
3 B 3-1\end{array}$ & $\begin{array}{l}538.9 \\
434.7 \\
418.8 \\
528.5 \\
459.5\end{array}$ & $\begin{array}{l}78.1 \\
63.0 \\
60.7 \\
76.6 \\
66.6\end{array}$ & $\begin{array}{l}32.6 \\
32.2 \\
30.9 \\
46.9 \\
32.6\end{array}$ & $\begin{array}{l}4.73 \\
4.67 \\
4.49 \\
4.56 \\
4.73\end{array}$ & $\begin{array}{l}0.278 \\
0.286 \\
0.288 \\
0.256 \\
0.275\end{array}$ & $\begin{array}{l}\text { RTD }^{a} \\
\text { RTD } \\
\text { RTD } \\
\text { RTD } \\
\text { RTD }\end{array}$ \\
\hline Average & 464 & 67.2 & 31.9 & 4.63 & 0.284 & RTD \\
\hline $\begin{array}{l}3 A 1-3 \\
3 A 2-6 \\
3 B 2-12 \\
3 B 3-3 \\
3 B 4-14\end{array}$ & $\begin{array}{l}404 \\
507 \\
520 \\
419 \\
527\end{array}$ & $\begin{array}{l}58.6 \\
73.5 \\
75.3 \\
60.7 \\
76.6\end{array}$ & $\begin{array}{l}26.3 \\
31.1 \\
32.1 \\
30.1 \\
31.2\end{array}$ & $\begin{array}{l}3.82 \\
4.51 \\
4.65 \\
4.36 \\
4.52\end{array}$ & $\begin{array}{l}0.190 \\
0.265 \\
0.268 \\
0.238 \\
0.254\end{array}$ & $\begin{array}{l}\text { WET } \\
\text { WET } \\
\text { WET } \\
\text { WET }\end{array}$ \\
\hline Average & 476 & 69.0 & 30.1 & 4.37 & 0.243 & WET \\
\hline
\end{tabular}


TABLE 10. COMPRESSIVE PROPERTIES OF EPOXY MATRIX COMPOSITES WITH WINDING PATTERN NO. 1

\begin{tabular}{|c|c|c|c|c|c|c|}
\hline $\begin{array}{l}\text { Specimen } \\
\text { Number } \\
\end{array}$ & $\begin{array}{l}\text { Compressive } \\
\text { Megapascals }\end{array}$ & $\frac{\text { Strength }}{\text { ksi }}$ & $\frac{\text { ModuTus of }}{\text { Gigapascal }}$ & $\frac{\text { Elasticity }}{\underline{\mathrm{s}} \quad \mathrm{10}^{6} \text { psi }}$ & $\begin{array}{c}\text { Poisson's } \\
\text { Ratio } \\
\end{array}$ & $\begin{array}{c}\text { Test } \\
\text { Condition }\end{array}$ \\
\hline $\begin{array}{l}3 A 1-21 \\
3 B 4-81 \\
3 b 4-82 \\
3 B 4-83 \\
3 A 1-131 \\
3 B 2-51 \\
3 A 3-92 \\
3 A 3-93 \\
3 B 1-22 \\
3 B 1-23 \\
3 B 4-31\end{array}$ & $\begin{array}{l}367.1 \\
398.1 \\
390.5 \\
387.8 \\
382.3 \\
382.9 \\
382.3 \\
363.6 \\
380.2 \\
442.3 \\
346.4\end{array}$ & $\begin{array}{l}53.2 \\
57.7 \\
56.6 \\
56.2 \\
55.4 \\
55.5 \\
55.4 \\
52.7 \\
55.1 \\
64.1 \\
50.2\end{array}$ & $\begin{array}{l}-- \\
-- \\
-- \\
-- \\
-- \\
-- \\
32.8 \\
33.1 \\
32.4 \\
30.6 \\
30.1\end{array}$ & $\begin{array}{l}-- \\
-- \\
-- \\
-- \\
-- \\
-- \\
4.76 \\
4.80 \\
4.70 \\
4.44 \\
4.36\end{array}$ & $\begin{array}{l}-- \\
-- \\
-- \\
-- \\
-- \\
-- \\
0.330 \\
0.320 \\
0.270 \\
0.300 \\
0.280\end{array}$ & $\begin{array}{l}\text { RTD } \\
\text { RTD } \\
\text { RTD } \\
\text { RTD } \\
\text { RTD } \\
\text { RTD } \\
\text { RTD } \\
\text { RTD } \\
\text { RTD } \\
\text { RTD } \\
\text { RTD }\end{array}$ \\
\hline Average & 384 & 55.6 & 31.8 & 4.61 & 0.300 & RTD \\
\hline $\begin{array}{l}3 A 2-42 \\
3 A 2-41 \\
3 B 1-41 \\
3 B 1-42 \\
3 B 4-52\end{array}$ & $\begin{array}{l}423.0 \\
378.8 \\
360-2 \\
342.2 \\
398.1\end{array}$ & $\begin{array}{l}61.3 \\
54.9 \\
52.2 \\
49.6 \\
57.7\end{array}$ & $\begin{array}{l}31.9 \\
30.6 \\
29.8 \\
31.2 \\
31.3\end{array}$ & $\begin{array}{l}4.62 \\
4.44 \\
4.32 \\
4.52 \\
4.53\end{array}$ & $\begin{array}{l}-- \\
-- \\
-- \\
-- \\
--\end{array}$ & $\begin{array}{l}\text { WET } \\
\text { WET } \\
\text { WET } \\
\text { WET } \\
\text { WET }\end{array}$ \\
\hline Average & 380.2 & 55.1 & 31.0 & 4.49 & -- & WET \\
\hline
\end{tabular}

$$
\begin{aligned}
& a_{T}=27^{\circ} \mathrm{C}\left(70^{\circ} \mathrm{F}\right), \quad R H=50 \% \\
& b_{T}=49^{\circ} \mathrm{C}\left(120^{\circ} \mathrm{F}\right), \quad R H=98 \% \text { for } 500 \text { hours }
\end{aligned}
$$


TABLE 11. TENSILE PROPERTIES OF EPOXY MATRIX COMPOSITES WITH WINDING PATTERN NO. 2

\begin{tabular}{|c|c|c|c|c|c|c|}
\hline Specimen & Tensile Str & ngth. & Modulus of & asticity & Poisson's & Test \\
\hline & Megapascals & ks i & Gigapascals & $10^{6} \mathrm{psi}$ & Ratio & Condition \\
\hline $\begin{array}{l}2 A T-5 \\
2 A 2-6 \\
2 A 3-9 \\
2 B 2-2 \\
2 B 3-11\end{array}$ & $\begin{array}{l}407.8 \\
418.8 \\
391.9 \\
451.9 \\
398.1\end{array}$ & $\begin{array}{l}59.1 \\
60.7 \\
56.8 \\
65.5 \\
57.7\end{array}$ & $\begin{array}{l}27.3 \\
25.3 \\
25.9 \\
28.2 \\
25.6\end{array}$ & $\begin{array}{l}3.96 \\
3.67 \\
3.75 \\
4.08 \\
3.71\end{array}$ & $\begin{array}{l}0.309 \\
0.292 \\
0.307 \\
0.330 \\
0.322\end{array}$ & $\begin{array}{l}\text { RTD } \\
\text { RTD } \\
\text { RTD } \\
\text { RTD } \\
\text { RTD }\end{array}$ \\
\hline Average & 413 & 59.9 & 26.6 & 3.85 & 0.312 & RTD \\
\hline $\begin{array}{l}2 A 3-10 \\
2 A 4-2 \\
2 B 1.12 \\
2 B 3-5 \\
2 B 3-13\end{array}$ & $\begin{array}{l}416 \\
413 \\
372 \\
358 \\
375\end{array}$ & $\begin{array}{l}60.3 \\
59.9 \\
53.9 \\
51.9 \\
54.3\end{array}$ & $\begin{array}{l}23.6 \\
25.9 \\
22.6 \\
22.4 \\
24.0\end{array}$ & $\begin{array}{l}3.42 \\
3.76 \\
3.28 \\
3.25 \\
3.48\end{array}$ & $\begin{array}{l}0.272 \\
0.337 \\
0.430 \\
0.296 \\
0.320\end{array}$ & $\begin{array}{l}\text { WET } \\
\text { WET } \\
\text { WET } \\
\text { WET } \\
\text { WET }\end{array}$ \\
\hline Average & 386 & 56.0 & 23.7 & 3.44 & 0.331 & WET \\
\hline
\end{tabular}


TABLE 12. COMPRESSIVE PROPERTIES OF EPOXY MATRIX COMPOSITES WITH WINDING PATTERN NO. 2

\begin{tabular}{|c|c|c|c|c|c|c|}
\hline $\begin{array}{l}\text { Specimen } \\
\text { Number }\end{array}$ & \multicolumn{2}{|c|}{ Compressive Strength } & \multicolumn{2}{|c|}{ Modulus of Elasticity } & $\begin{array}{c}\text { Poisson's } \\
\text { Ratio } \\
\end{array}$ & $\begin{array}{c}\text { Test } \\
\text { Condition }\end{array}$ \\
\hline $\begin{array}{l}2 A 4-111 \\
2 A 4-112 \\
2 A 4-113 \\
2 B 1-52 \\
2 B 1-53 \\
2 B 1-51 \\
2 A 1-101 \\
2 A 1-102 \\
2 A 3-71 \\
2 A 3-72 \\
2 B 1-11\end{array}$ & $\begin{array}{l}358.1 \\
382.3 \\
382.3 \\
371.9 \\
349.8 \\
362.9 \\
362.9 \\
354.7 \\
280.1 \\
302.9 \\
307.1\end{array}$ & $\begin{array}{l}51.9 \\
55.4 \\
55.4 \\
53.9 \\
50.7 \\
52.6 \\
38.1 \\
51.4 \\
40.7 \\
43.9 \\
44.5\end{array}$ & $\begin{array}{c}-- \\
-- \\
-- \\
-- \\
-- \\
-- \\
24.0 \\
22.4 \\
24.2 \\
28.3 \\
27.6\end{array}$ & $\begin{array}{l}-- \\
-- \\
-- \\
-- \\
-- \\
-- \\
3.48 \\
3.24 \\
3.50 \\
4.10 \\
4.00\end{array}$ & $\begin{array}{l}-- \\
-- \\
-- \\
-- \\
-- \\
-- \\
0.310 \\
0.280 \\
0.350 \\
0.300 \\
0.350\end{array}$ & $\begin{array}{l}\text { RTD } \\
\text { RTD } \\
\text { RTD } \\
\text { RTD } \\
\text { RTD } \\
\text { RTD } \\
\text { RTD } \\
\text { RTD } \\
\text { RTD } \\
\text { RTD } \\
\text { RTD }\end{array}$ \\
\hline Average & 345.2 & 48.6 & 25.3 & 3.67 & 0.378 & RTD \\
\hline $\begin{array}{l}2 A 4-131 \\
2 A 4-132 \\
2 A 3-131 \\
2 B 2-131 \\
2 B 2-132\end{array}$ & $\begin{array}{l}387.8 \\
340.9 \\
303.6 \\
378.1 \\
381.6\end{array}$ & $\begin{array}{l}56.2 \\
49.4 \\
44.0 \\
54.8 \\
55.3\end{array}$ & $\begin{array}{l}29.6 \\
27.7 \\
28.2 \\
26.6 \\
23.2^{c}\end{array}$ & $\begin{array}{l}4.29 \\
4.01 \\
4.08 \\
3.86 \\
3.36 \mathrm{c}\end{array}$ & $\begin{array}{l}-- \\
-- \\
-- \\
-- \\
--\end{array}$ & $\begin{array}{l}\text { WET } \\
\text { WET } \\
\text { WET } \\
\text { WET } \\
\text { WET }\end{array}$ \\
\hline Average & 358.1 & 51.9 & 27.1 & 4.06 & & WET \\
\hline
\end{tabular}


TABLE 13. TENSILE PROPERTIES OF POLYESTER MATRIX COMPOSITES

\begin{tabular}{|c|c|c|c|c|c|c|}
\hline \multirow{2}{*}{$\begin{array}{l}\text { Specimen } \\
\text { Number }\end{array}$} & \multicolumn{2}{|c|}{ Tensile Strength } & \multicolumn{2}{|c|}{ Modulus of Elasticity } & \multirow{2}{*}{$\begin{array}{c}\text { Poisson's } \\
\text { Ratio }\end{array}$} & \multirow{2}{*}{$\begin{array}{c}\text { Test } \\
\text { Condition }\end{array}$} \\
\hline & Megapascals & ksi & Gigapascals & $10^{6} \mathrm{psi}$ & & \\
\hline $\begin{array}{l}4 A-T 2 \\
4 B-T C \\
4 A-T 6 C \\
4 B-T 3 C \\
4 B-T 5 C \\
4 A-T 15 \\
4 A-T 17 \\
4 A-T 19\end{array}$ & $\begin{array}{c}440.9 \\
-- \\
-- \\
412.6 \\
-- \\
453.5 \\
441.5 \\
485.0\end{array}$ & $\begin{array}{r}63.9 \\
-- \\
-- \\
59.8 \\
-- \\
65.7 \\
64.0 \\
70.3\end{array}$ & $\begin{array}{c}26.01 \\
25.74 \\
25.05 \\
24.15 \\
24.70 \\
-- \\
-- \\
--\end{array}$ & $\begin{array}{r}3.77 \\
3.73 \\
3.63 \\
3.50 \\
3.58 \\
-- \\
-- \\
--\end{array}$ & $\begin{array}{c}0.272 \\
0.291 \\
0.275 \\
0.286 \\
0.279 \\
-- \\
-- \\
--\end{array}$ & $\begin{array}{l}\text { RTD } \\
\text { RTD } \\
\text { RTD } \\
\text { RTD } \\
\text { RTD } \\
\text { RTD } \\
\text { RTD } \\
\text { RTD }\end{array}$ \\
\hline Average & 446.7 & 64.7 & 25.33 & 3.64 & 0.281 & RTD \\
\hline $\begin{array}{l}4 A-T 1 \\
4 B-T 2 \\
4 A-T 16 \\
4 A-T 18 \\
4 A-T 20\end{array}$ & $\begin{array}{l}420.9 \\
418.1 \\
463.0 \\
459.7 \\
445.5\end{array}$ & $\begin{array}{l}61.0 \\
60.2 \\
67.1 \\
66.6 \\
64.6\end{array}$ & $\begin{array}{c}25.05 \\
27.19 \\
-- \\
--\end{array}$ & $\begin{array}{r}3.68 \\
3.94 \\
-- \\
-- \\
--\end{array}$ & $\begin{array}{c}0.265 \\
0.333 \\
-- \\
-- \\
--\end{array}$ & $\begin{array}{l}\text { WET } \\
\text { WET } \\
\text { WET } \\
\text { WET } \\
\text { WET }\end{array}$ \\
\hline Average & 441.1 & 63.9 & 26.12 & 3.81 & 0.299 & WET \\
\hline $\begin{array}{l}4 A-T 3 \\
4 A-T 5 \\
4 B-T 4 \\
4 B-T 6\end{array}$ & $\begin{array}{l}334.7 \\
316.0 \\
308.4 \\
320.9\end{array}$ & $\begin{array}{l}48.5 \\
45.8 \\
44.7 \\
46.5\end{array}$ & $\begin{array}{l}24.15 \\
26.08 \\
25.67 \\
25.16\end{array}$ & $\begin{array}{l}3.50 \\
3.78 \\
3.72 \\
3.62\end{array}$ & $\begin{array}{l}0.286 \\
0.264 \\
0.269 \\
0.276\end{array}$ & $\begin{array}{l}\text { Saturated } \\
\text { Saturated } \\
\text { Saturated } \\
\text { Saturated }\end{array}$ \\
\hline Average & 320.0 & 46.4 & 25.27 & 3.65 & 0.274 & Saturated \\
\hline
\end{tabular}

$\mathrm{a}_{\mathrm{T}}=27^{\circ} \mathrm{C}\left(70^{\circ} \mathrm{F}\right), \mathrm{RH}=50 \%$

$\mathrm{b}_{\mathrm{T}}=49^{\circ} \mathrm{C}\left(120^{\circ} \mathrm{F}\right), \mathrm{RH}=98 \%$; exposure for 500 hours

${ }^{\mathrm{C}}$ Tabs sheared from specimen prior to failure

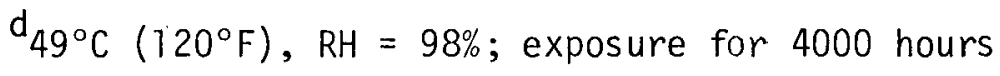


TABLE 14. COMPRESSIVE PROPERTIES OF POLYESTER MATRIX COMPOSITES

\begin{tabular}{|c|c|c|c|c|c|c|}
\hline $\begin{array}{l}\text { Specimen } \\
\text { Number } \\
\end{array}$ & $\begin{array}{l}\text { Compressive } \\
\text { Megapascals }\end{array}$ & $\frac{\text { ength }}{\text { ksi }}$ & $\frac{\text { Modulus of }}{\text { Gigapascals }}$ & $\frac{\text { sticity }}{10^{6} \mathrm{ps} i}$ & $\begin{array}{c}\text { Poisson's } \\
\text { Ratio } \\
\end{array}$ & $\begin{array}{c}\text { Test } \\
\text { Condition } \\
\end{array}$ \\
\hline $\begin{array}{l}4 A-C 7 \\
4 B-C 2 \\
4 B-C 5 \\
4 A-C 3 \\
4 B-C 4 \\
4 B-C 6\end{array}$ & $\begin{array}{l}387.8 \\
313.3 \\
313.3 \\
381.6 \\
256.0 \\
346.4\end{array}$ & $\begin{array}{l}56.2 \\
53.9 \\
45.4 \\
55.3 \\
37.1 \\
50.2\end{array}$ & $\begin{array}{l}28.50 \\
27.95 \\
29.12 \\
28.84 \\
34.16 \\
28.77\end{array}$ & $\begin{array}{l}4.13 \\
4.05 \\
4.22 \\
4.18 \\
4.95 \\
4.17\end{array}$ & $\begin{array}{l}0.264 \\
0.328 \\
0.237 \\
0.239 \\
0.202 \\
0.240\end{array}$ & $\begin{array}{l}\text { RTD }{ }^{a} \\
\text { RTD } \\
\text { RTD } \\
\text { RTD } \\
\text { RTD } \\
\text { RTD }\end{array}$ \\
\hline Average & 342.9 & 49.7 & 29.56 & 4.28 & 0.252 & RTD \\
\hline $\begin{array}{l}4 A-C 5 \\
4 B-C 7 \\
4 A-C 4 \\
4 B-C 3 \\
4 A-C 6 \\
4 A-C 2\end{array}$ & $\begin{array}{l}356.7 \\
346.4 \\
325.0 \\
285.7 \\
349.1 \\
331.9\end{array}$ & $\begin{array}{l}51.7 \\
50.2 \\
47.1 \\
41.4 \\
50.6 \\
48.1\end{array}$ & $\begin{array}{l}28.08 \\
28.29 \\
26.63 \\
28.43 \\
27.39 \\
31.40\end{array}$ & $\begin{array}{l}4.07 \\
4.10 \\
3.86 \\
4.12 \\
3.97 \\
4.55\end{array}$ & $\begin{array}{l}0.289 \\
0.291 \\
0.259 \\
0.243 \\
0.252 \\
0.220\end{array}$ & $\begin{array}{l}\text { WET } \\
\text { WET } \\
\text { WET } \\
\text { WET } \\
\text { WET } \\
\text { WET }\end{array}$ \\
\hline Average & 332.6 & 48.2 & 28.37 & 4.71 & 0.259 & WET \\
\hline
\end{tabular}

$\mathrm{a}_{\mathrm{T}}=21^{\circ} \mathrm{C}\left(70^{\circ} \mathrm{F}\right), \mathrm{RH}=50 \%$.

$\mathrm{b}_{\mathrm{T}}=49^{\circ} \mathrm{C}\left(120^{\circ} \mathrm{F}\right), \mathrm{RH}=98 \%$ for $500 \mathrm{hr}$. 
TABLE 15. INTERLAMINAR SHEAR STRENGTHS FOR EPOXY MATRIX COMPOSITE MATERIALS WITH WINDING PATTERN NOS. 1 AND 2 AT AMBIENT (RTD) a AND WETb CONDITIONS

\begin{tabular}{|c|c|c|c|c|}
\hline \multirow{2}{*}{$\begin{array}{l}\text { Winding } \\
\text { Pattern No. }\end{array}$} & \multirow{2}{*}{$\begin{array}{c}\text { Test } \\
\text { Condition } \\
\end{array}$} & \multirow{2}{*}{$\begin{array}{c}\text { Specimen } \\
\text { Number }\end{array}$} & \multicolumn{2}{|c|}{ Interlaminar Shear } \\
\hline & & & $\mathrm{MPa}$ & $\mathrm{ksi}$ \\
\hline \multirow[t]{7}{*}{1} & \multirow[t]{7}{*}{ RTD } & $3 A 291-1$ & 48.3 & 7.0 \\
\hline & & $3 A 291-2$ & 42.1 & 6.1 \\
\hline & & $3 B 192-1$ & 46.9 & 6.8 \\
\hline & & $3 B 192-2$ & 42.1 & 6.1 \\
\hline & & $3 B 441-1$ & 39.3 & 5.7 \\
\hline & & $3 B 441-2$ & 42.8 & 6.2 \\
\hline & & Average & 43.5 & 6.3 \\
\hline \multirow[t]{7}{*}{1} & \multirow[t]{7}{*}{ Wet } & $3 A 2-411$ & 79.3 & 11.5 \\
\hline & & $3 A 2-412$ & 75.2 & 10.9 \\
\hline & & $3 B 1-1011$ & 75.9 & 11.0 \\
\hline & & $3 B 1-1012$ & 73.8 & 10.7 \\
\hline & & $3 B 4-1321$ & 76.6 & 17.1 \\
\hline & & $3 B 4-1322$ & 67.6 & 9.8 \\
\hline & & Average & 74.5 & 10.8 \\
\hline \multirow[t]{7}{*}{2} & \multirow[t]{7}{*}{ RTD } & $2 A 131-1$ & 42.8 & 6.2 \\
\hline & & $2 A 131-2$ & 56.6 & 8.2 \\
\hline & & $2 A 3132-1$ & 61.4 & 8.9 \\
\hline & & $2 A 3132-2$ & 50.4 & 7.3 \\
\hline & & $2 B 111-1$ & 44.2 & 6.4 \\
\hline & & $2 \mathrm{~B} 111-2$ & 41.4 & 6.0 \\
\hline & & Average & 49.7 & 7.2 \\
\hline \multirow[t]{7}{*}{2} & \multirow[t]{7}{*}{ Wet } & $2 A 1-311$ & 82.8 & 12.0 \\
\hline & & $2 A 1-312$ & 79.4 & 11.5 \\
\hline & & $2 A 2-811$ & 63.5 & 9.2 \\
\hline & & $2 A 2-812$ & 69.0 & 10.0 \\
\hline & & $2 B 1-711$ & 75.9 & 11.0 \\
\hline & & $2 \mathrm{~B} 1-712$ & 66.2 & 9.6 \\
\hline & & Average & 72.8 & 10.5 \\
\hline
\end{tabular}


TABLE 16. INTERLAMINAR SHEAR STRENGTH

FOR POLYESTER MATRIX COMPOSITES AT

AMBIENT (RTD) a AND WETb CONDITIONS

\begin{tabular}{|c|c|c|c|}
\hline \multirow{2}{*}{$\begin{array}{c}\text { Test } \\
\text { Condition } \\
\end{array}$} & \multirow{2}{*}{$\begin{array}{l}\text { Specimen } \\
\text { No. }\end{array}$} & \multicolumn{2}{|c|}{$\begin{array}{l}\text { Interlaminar } \\
\text { Shear Strength }\end{array}$} \\
\hline & & $\mathrm{MPa}$ & ksi \\
\hline \multirow[t]{6}{*}{ RTD } & $4 \mathrm{~A}-\mathrm{Sl}_{2}$ & 76.6 & 11.1 \\
\hline & $4 A-S 2_{2}$ & 74.5 & 10.8 \\
\hline & $4 \mathrm{~A}-\mathrm{S} 32$ & 70.4 & 10.2 \\
\hline & $4 A-S 42$ & 71.8 & 10.4 \\
\hline & $4 A-S 5_{2}$ & 69.7 & 10.1 \\
\hline & $4 A-S 6_{2}$ & 71.7 & 10.3 \\
\hline Average & & 72.4 & 10.5 \\
\hline \multirow[t]{6}{*}{ Wet } & $4 A-S I_{I}$ & 66.9 & 9.7 \\
\hline & $4 A-S 2_{1}$ & 64.9 & 9.4 \\
\hline & $4 A-S 3_{1}$ & 61.4 & 8.9 \\
\hline & $4 A-S 4_{1}$ & 62.8 & 9.1 \\
\hline & $4 A-S 5_{1}$ & 61.4 & 8.9 \\
\hline & $4 A-S 6_{1}$ & 64.9 & 9.4 \\
\hline Average & & 63.7 & 9.2 \\
\hline
\end{tabular}




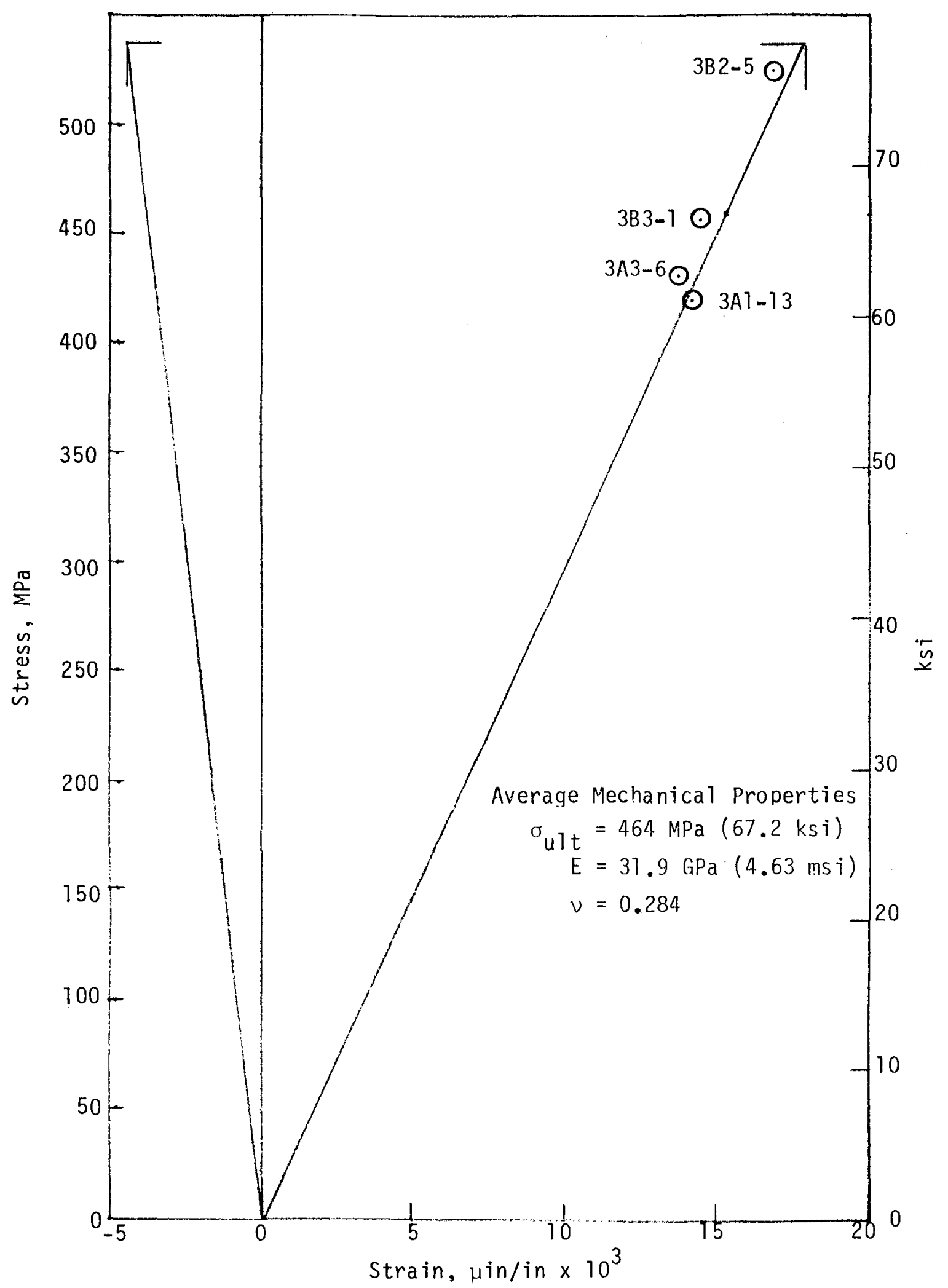

Figure 31. Tensile stress-strain curve for epoxy matrix composites with winding pattern No. 1 tested dry at room temperature. Curve shown for Specimen No. 3B4-7, endpoints of other tests shown by circles.. 


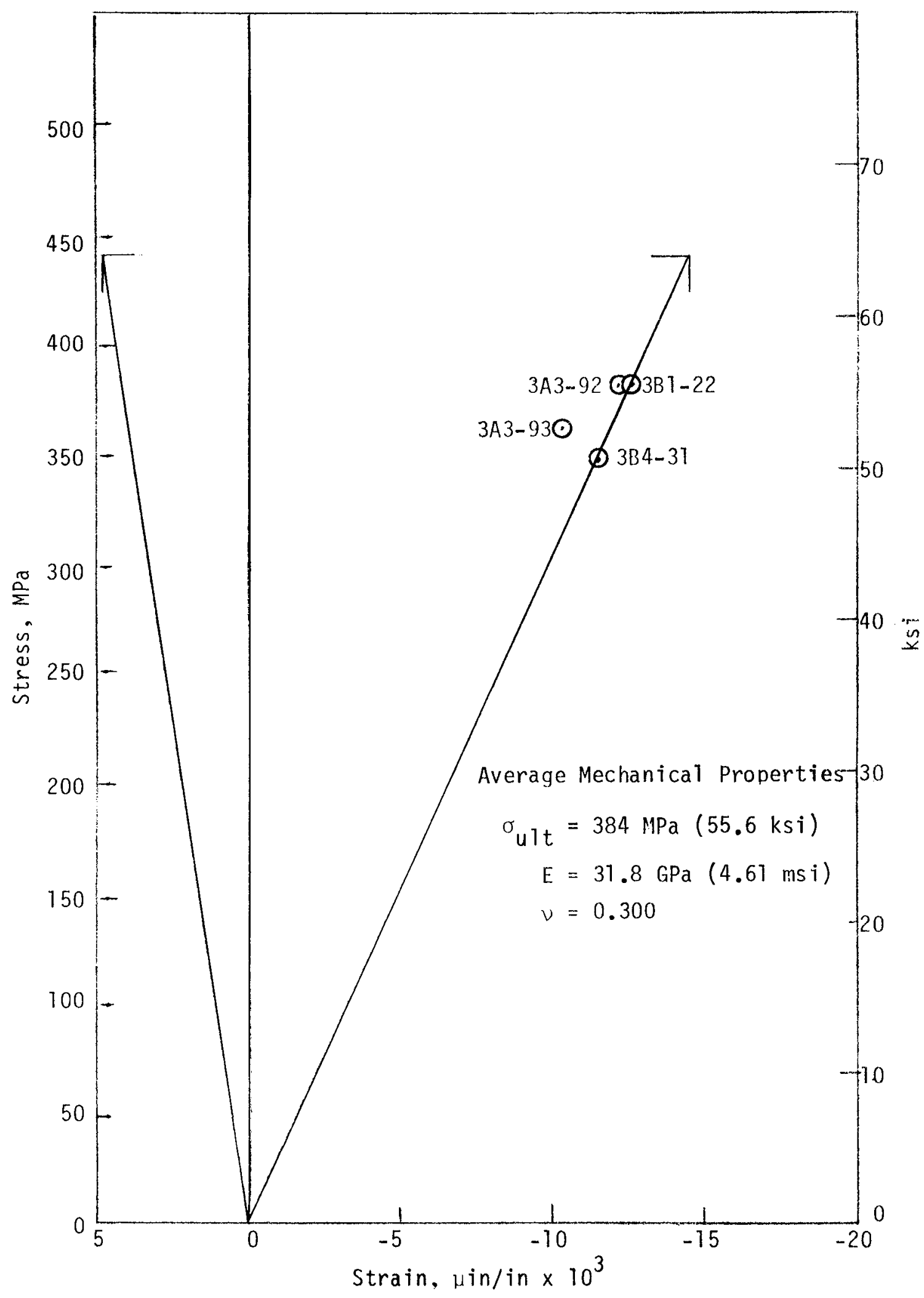

Figure 32. Compressive stress-strain curve for epoxy matrix composites with winding pattern No. 1 tested dry at room temperature. Curve shown for specimen No. 3B1-23, endpoints of other tests shown by circles. 


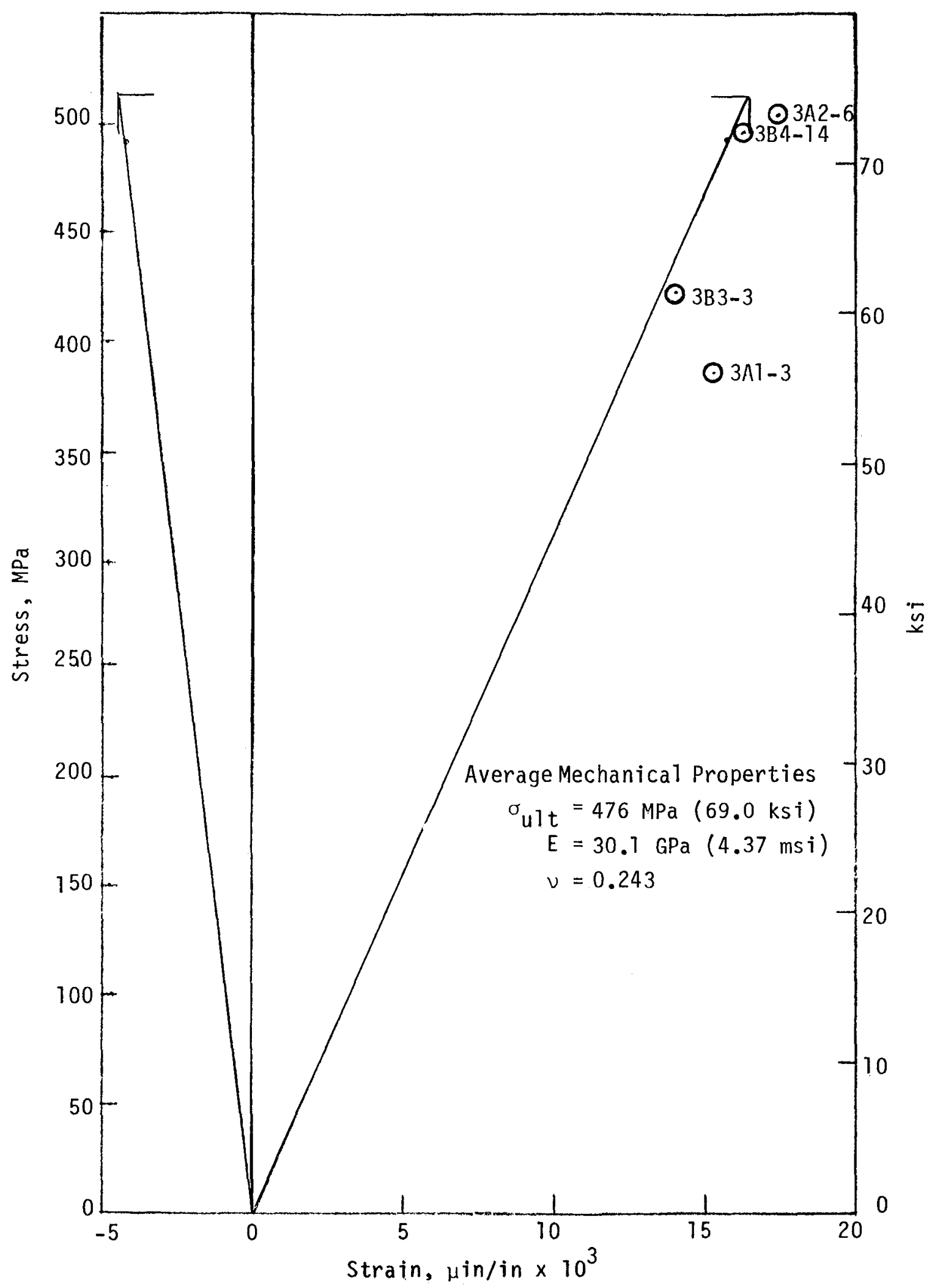

Figure 33. Tensile stress-strain curve for epoxy matrix composites with winding pattern No. 1 tested wet at $49^{\circ} \mathrm{C}\left(120^{\circ} \mathrm{F}\right)$. Curve shown for Specimen No. 3B2-12, endpoints of other tests shown by circles. 


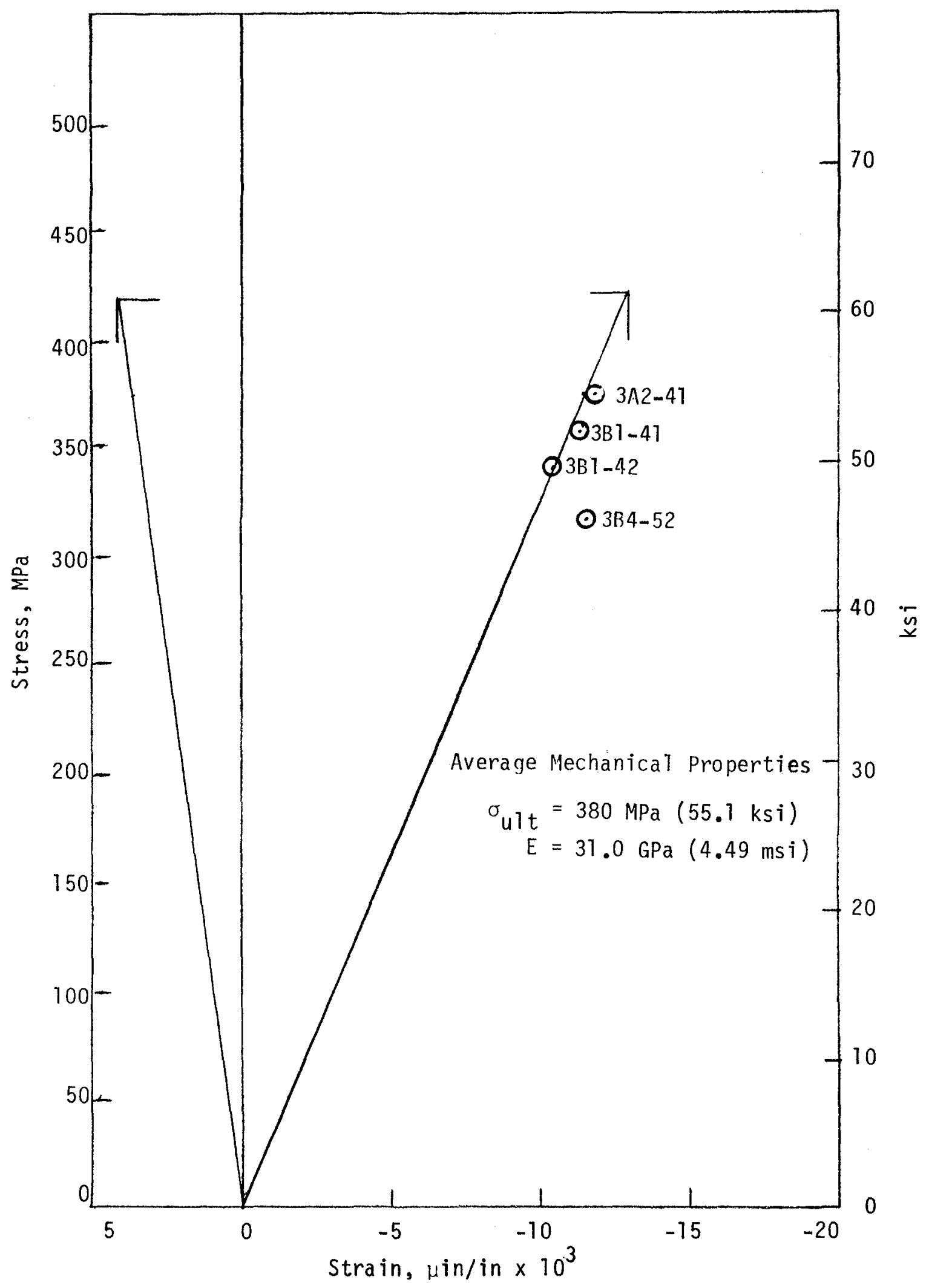

Figure 34. Compressive stress-strain curve for epoxy matrix composites with winding pattern No. 1 tested wet at $49^{\circ} \mathrm{C}\left(120^{\circ} \mathrm{F}\right)$. Curve shown for Specimen No. 3A2-42, endpoints of other tests shown by circles. 


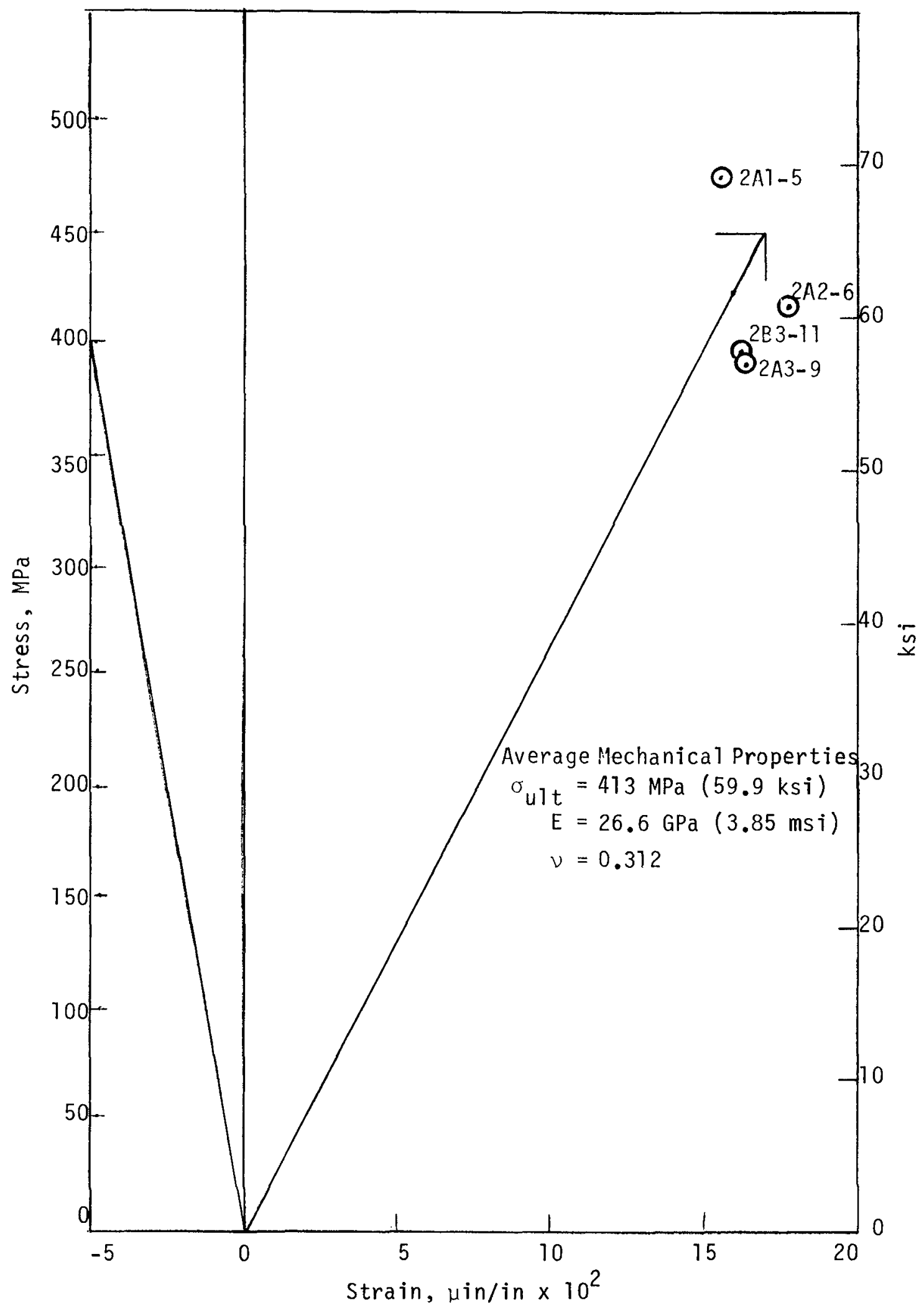

Figure 35. Tensile stress-strain curve for epoxy matrix composites with winding pattern No. 2 tested dry at room temperature. Curve shown for specimen No. 2B2-2, endpoints of other tests shown by circles. 


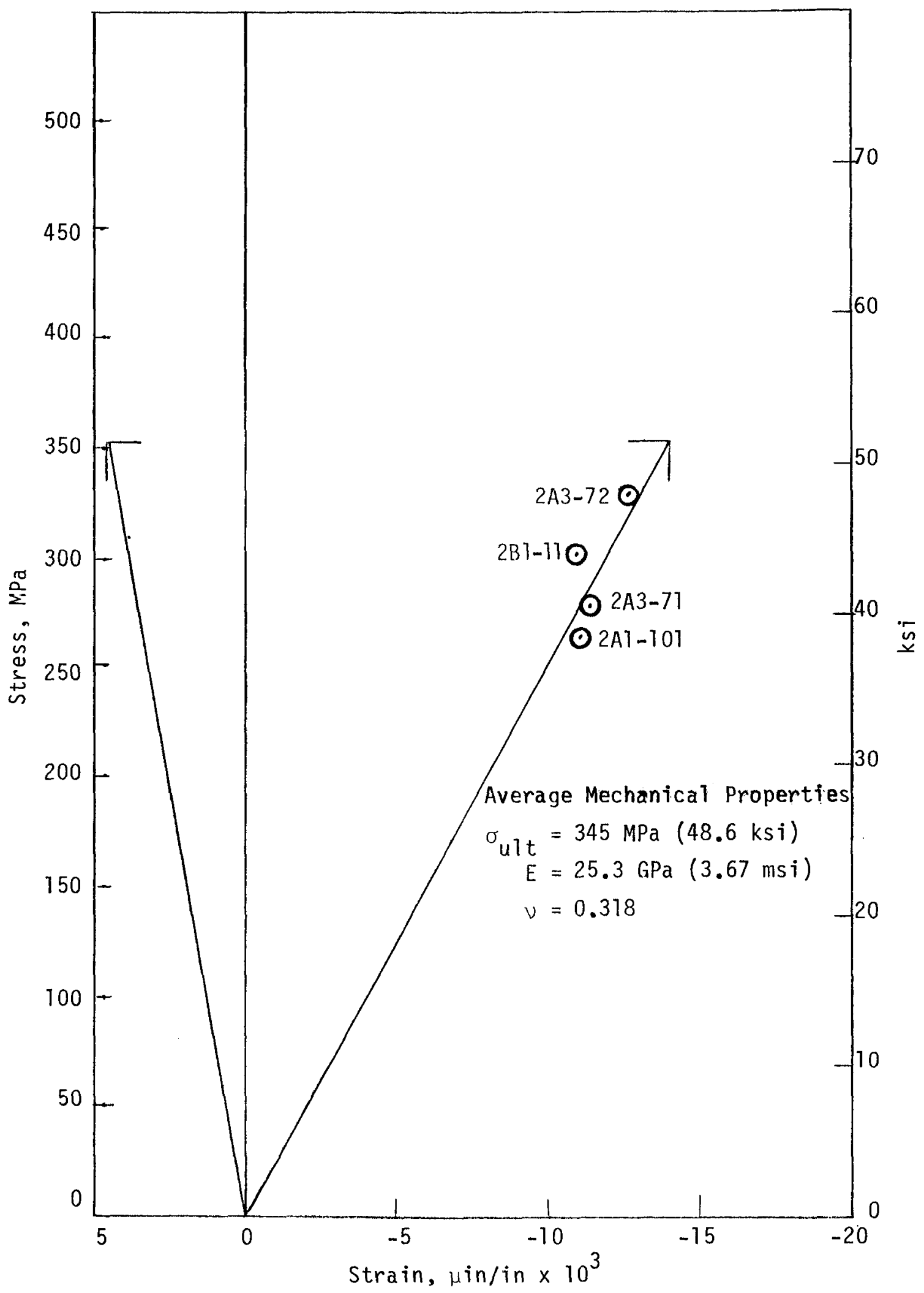

Figure 36. Compressive stress-strain curve for epoxy matrix composites with winding pattern No. 2 tested dry at room temperature. Curve shown for Specimen No. 2A1-102, endpoints of other tests shown by circles. 


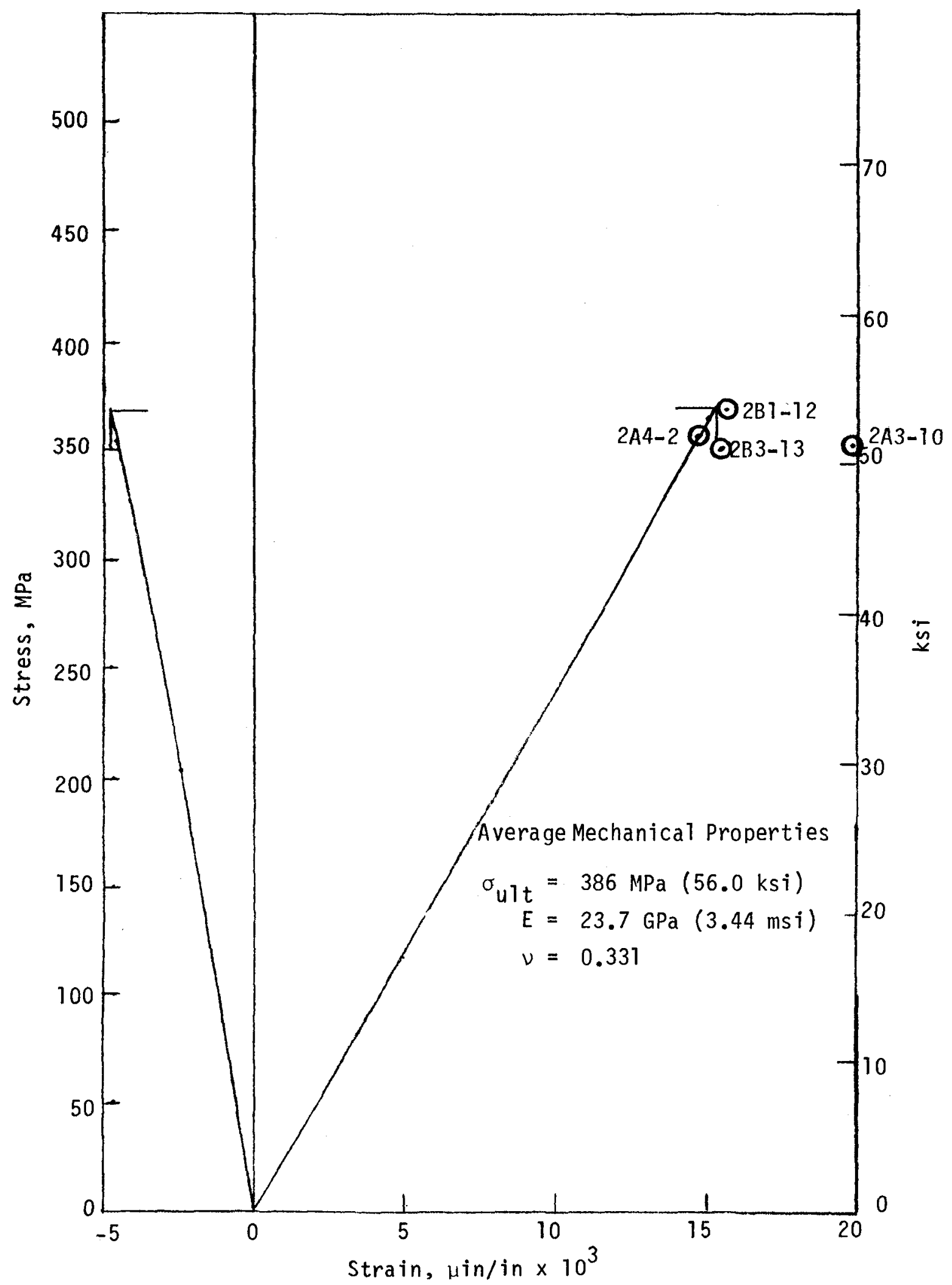

Figure 37. Tensile stress-strain curve for epoxy matrix composites with winding pattern No. 2 tested wet at $49^{\circ} \mathrm{C}\left(120^{\circ} \mathrm{F}\right)$. Curve shown for Specimen No. 2B3-5, endpoints of other tests shown by circles. 


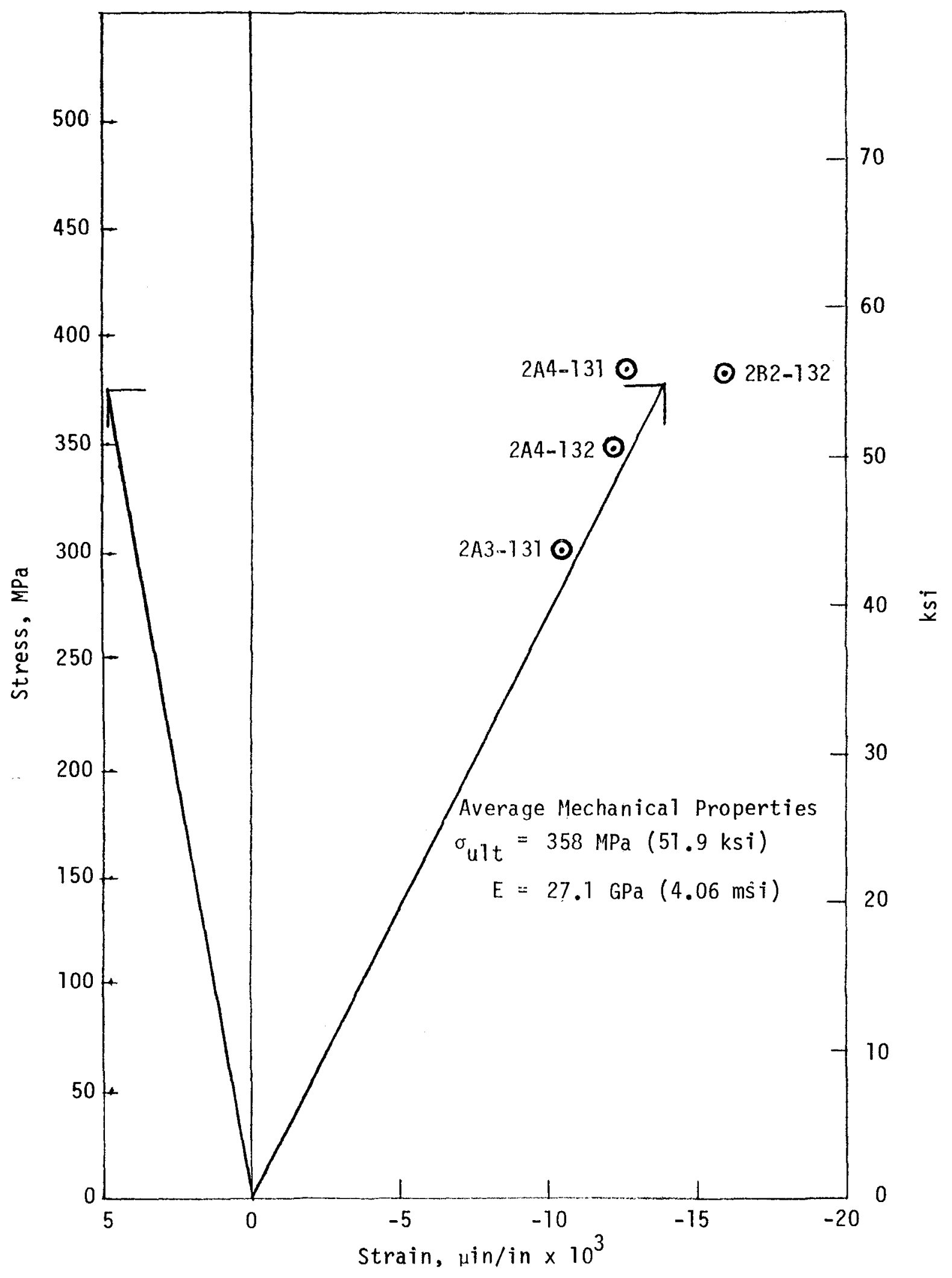

Figure 38. Compressive stress-strain curve for epoxy matrix composites with winding pattern No. 2 tested wet at $49^{\circ} \mathrm{C}\left(120^{\circ} \mathrm{F}\right)$. Curve shown for Specimen No. 2B2-131, endpoints of other tests shown by circles. 


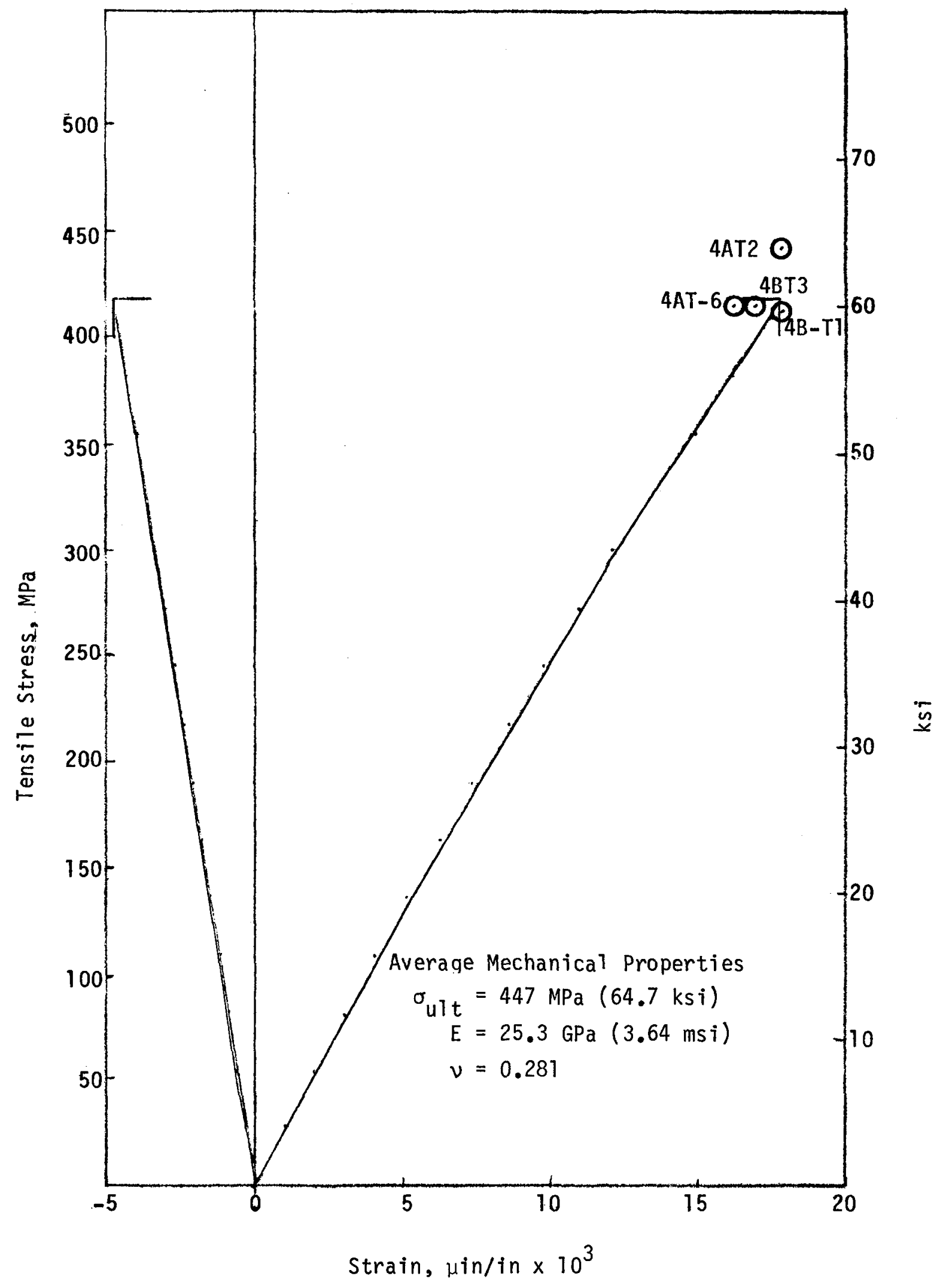

Figure 39. Tensile stress-strain curve for polyester matrix composites tested dry at room temperature. Curve shown for Specimen No. 4B-T5, endpoints of other tests shown by circles. 


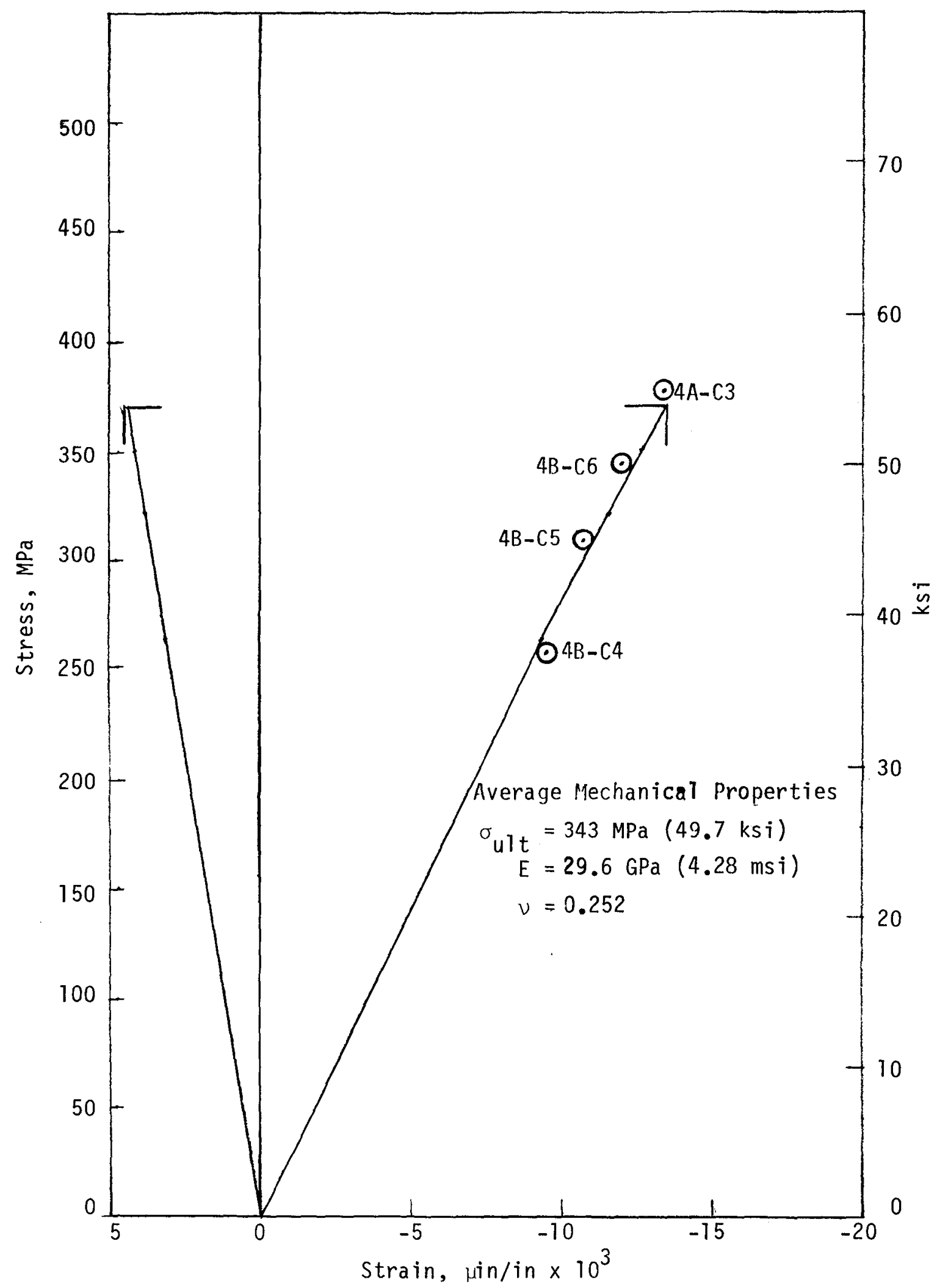

Figure 40. Compressive stress-strain curve for polyester matrix composites tested dry at room temperature. Curve shown for Specimen No. $4 \mathrm{~B}-\mathrm{C} 2$, endpoints of other tests shown by circles. 


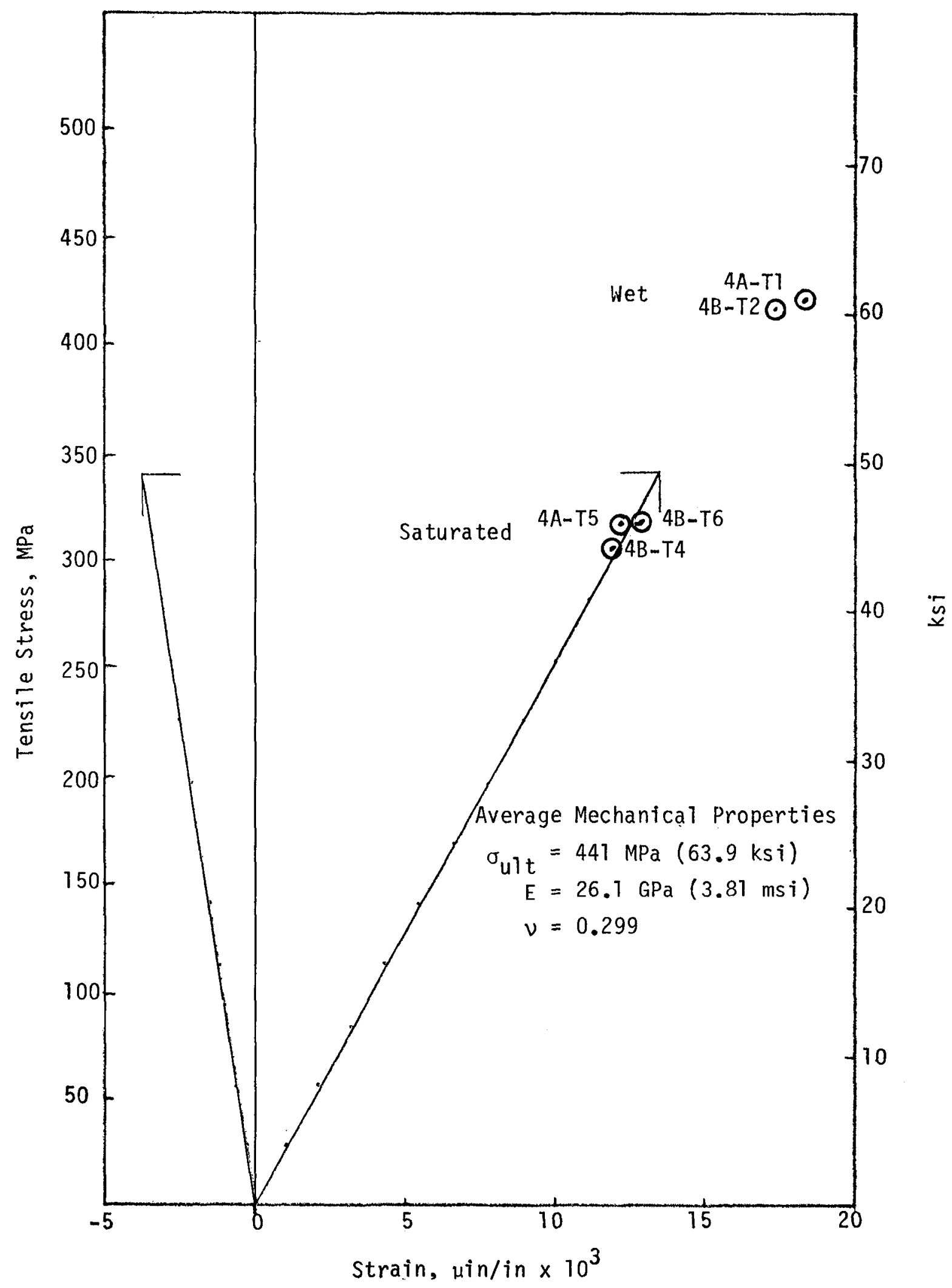

Figure 41. Tensile stress-strain curve for polyester matrix composites tested wet at $49^{\circ} \mathrm{C}\left(120^{\circ} \mathrm{F}\right)$. Curve shown for Specimen No. 4A-T3, endpoints of other tests shown by circles. 


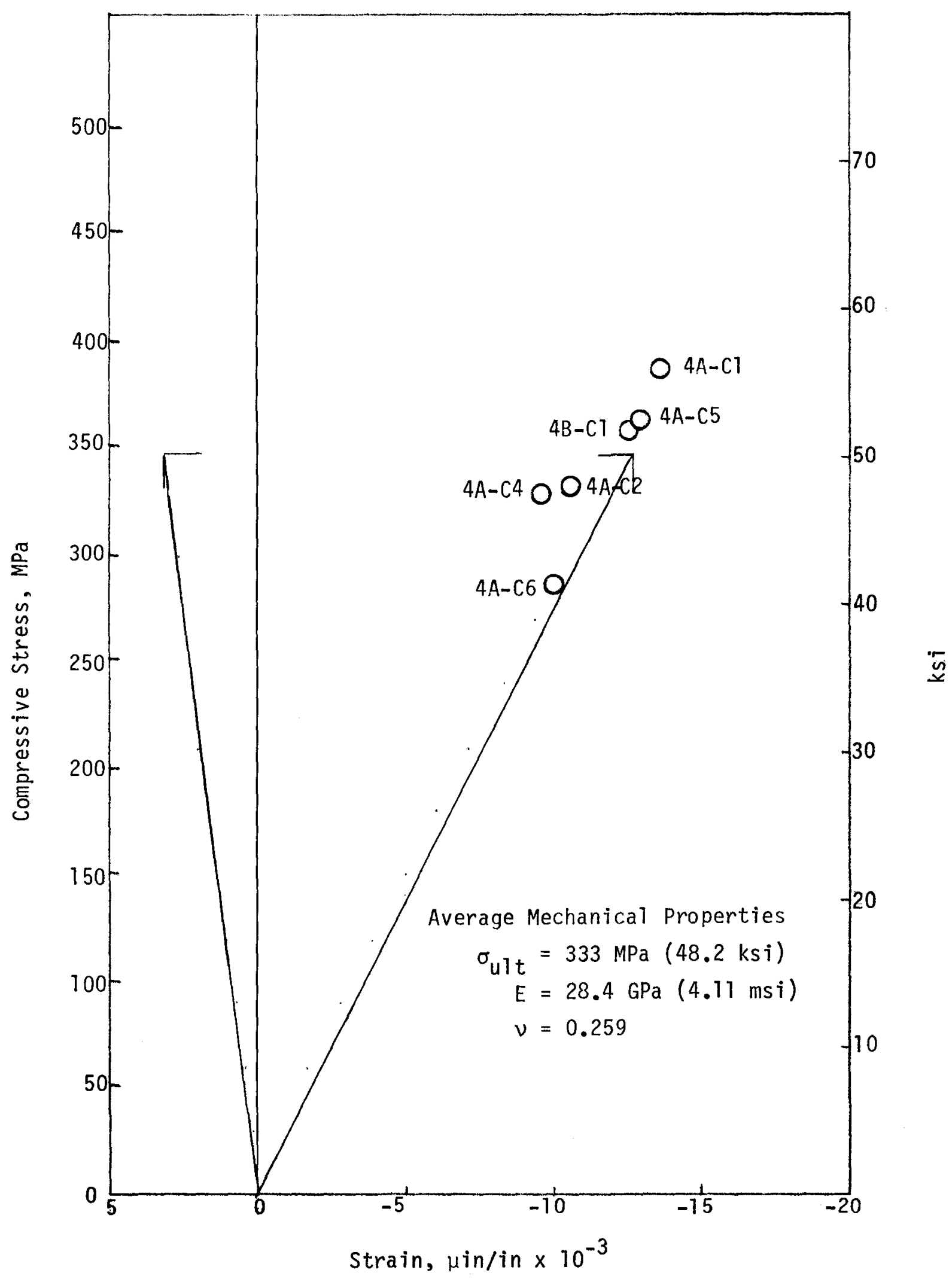

Figure 42: Compressive stress-strain curve for polyester matrix composites tested wet at $49^{\circ} \mathrm{C}\left(120^{\circ} \mathrm{F}\right)$. Curve shown for specimen No. $4 A-C 6$, endpoints of other tests shown by circles. 
. 


\section{APPENDIX C: INDIVIDUAL FATIGUE DATA}

Individual fatigue data are assembled in this appendix. The curves presented in the text of this report were derived from these individual fatigue test data. Several $R^{*}$ ratios, including $R=0,-0.1,-0.25,-0.5$, and -1.0 , were evaluated. Two environmental conditions were maintained during testing: 1) dry or ambient conditions, i.e., $T=21^{\circ} \mathrm{C}\left(70^{\circ} \mathrm{F}\right)$, and R.H. $=50 \%$; and 2) wet conditions, i.e., $\mathrm{T}=49^{\circ} \mathrm{C}\left(120^{\circ} \mathrm{F}\right)$, and R.H. $=98 \%$. In most cases testing was terminated after exposure to $10,000,000$ stress cycles.

A post-failure examination of the fatigue failures was made and the following observations reported:

The pattern No. 1 epoxy matrix specimen exhibited brooming failures dry but not wet at $R=0$. As the $R$ ratio included increasingly large compression components (from $R=-0.1,-0.25,-0.5$ to -0.1 ), some splitting and brooming occurred.

Pattern No. 2 epxoy matrix specimens generally exhibited tab failures for all $R$ ratios. Very few wet failures were available since stress levels were below the threshold of fatigue failures.

The polyester failure modes for fatigue were similar to those for the static loading. The tension-tension $(R=0)$ fatigue failures were similar, dry and wet to static tension failures. The $R=-1$ (fully reversed) fatigue failures were similar to the static compression failures.

\footnotetext{
${ }^{*} \mathrm{R}$ is the ratio of the minimum algebraic stress per cycle to the maximum algebraic stress per cycle.
} 
TABLE 17 . FATIGUE ENDURANCES FOR EPOXY MATRIX MATERIAL WITH WINDING PATTERN NO. 1 AT VARIOUS R RATIOS

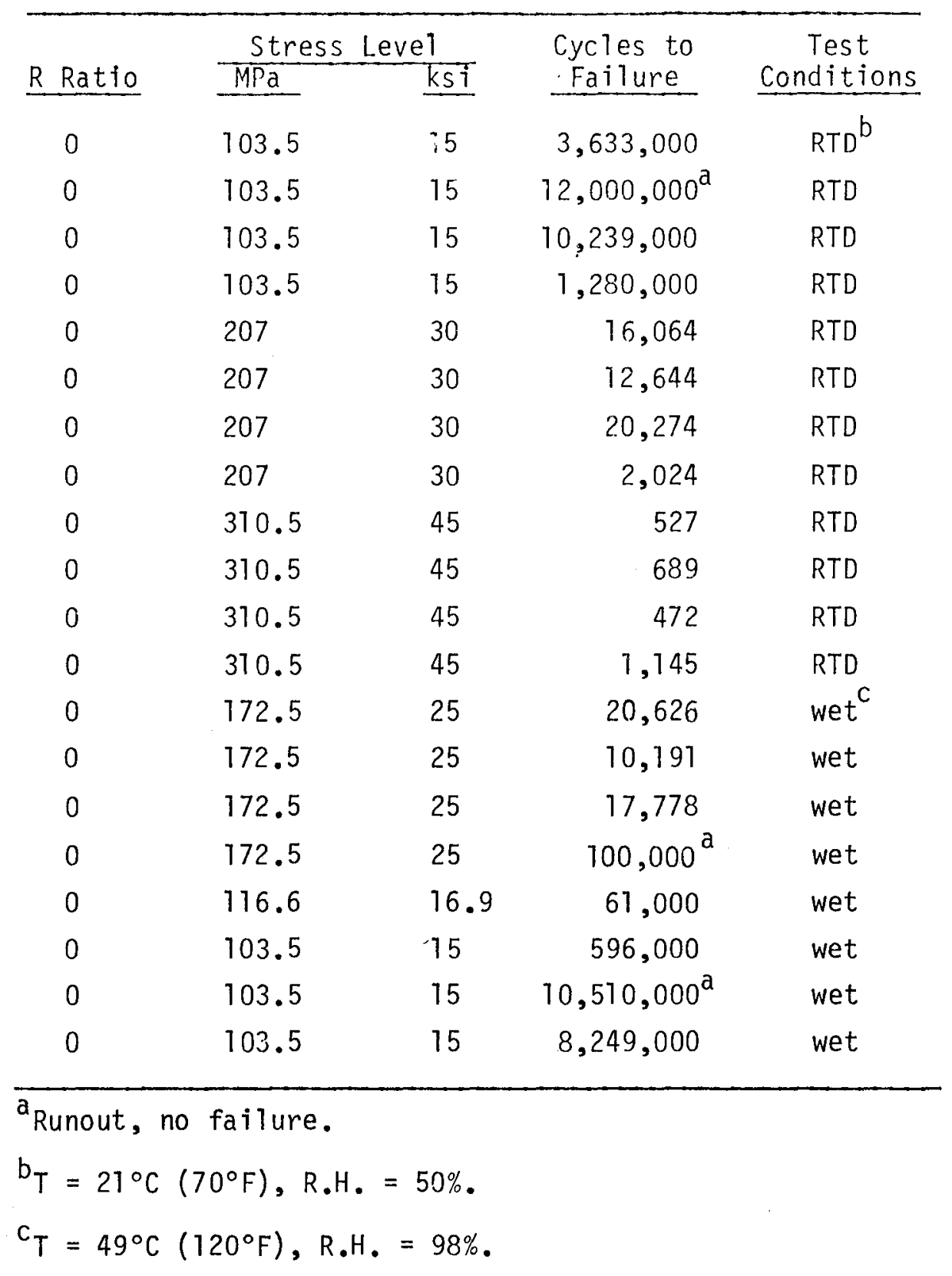


TABLE 17 (cont.)

\begin{tabular}{|c|c|c|c|c|}
\hline \multirow[b]{2}{*}{ R Ratio } & \multicolumn{2}{|c|}{ Stress Level } & \multirow{2}{*}{$\begin{array}{c}\text { Cycles to } \\
\text { Failure }\end{array}$} & \multirow{2}{*}{$\begin{array}{c}\text { Test } \\
\text { Conditions } \\
\end{array}$} \\
\hline & $\mathrm{MPa}$ & ksi & & \\
\hline-0.1 & 172.5 & 25 & 34,186 & $\operatorname{RTD}^{\mathrm{b}}$ \\
\hline-0.1 & 172.5 & 25 & 13,766 & RTD \\
\hline-0.1 & 172.5 & 25 & 7,450 & RTD \\
\hline-0.1 & 172.5 & 25 & 9,810 & RTD \\
\hline-0.1 & 82.8 & 12 & $17,378,000^{\mathrm{a}}$ & RTD \\
\hline-0.1 & 82.8 & 12 & $15,150,000^{\mathrm{a}}$ & RTD \\
\hline-0.1 & 82.8 & 12 & $10,700,000^{\mathrm{a}}$ & RTD \\
\hline-0.1 & 82.8 & 12 & $12,341,000^{a}$ & RTD \\
\hline-0.1 & 82.8 & 12 & $10,070,000^{\mathrm{a}}$ & RTD \\
\hline-0.1 & 172.5 & 25 & $100,000^{\mathrm{a}}$ & wet $^{\mathrm{c}}$ \\
\hline-0.1 & 172.5 & 25 & 10,983 & wet \\
\hline-0.1 & 172.5 & 25 & 18,833 & wet \\
\hline-0.1 & 172.5 & 25 & 67,533 & wet \\
\hline-0.1 & 82.8 & 12 & $17,378,000^{\mathrm{a}}$ & wet \\
\hline-0.25 & 82.8 & 12 & $1,296,000$ & RTD \\
\hline-0.25 & 82.8 & 12 & $5,290,000$ & RTD \\
\hline-0.25 & 82.8 & 12 & $12,384,000^{\mathrm{a}}$ & RTD \\
\hline-0.25 & 82.8 & 12 & $12,371,000^{\mathrm{a}}$ & RTD \\
\hline-0.25 & 82.8 & 12 & $12,239,000^{\mathrm{a}}$ & RTD \\
\hline-0.25 & 82.8 & 12 & $12,321,000^{\mathrm{a}}$ & wet \\
\hline-0.25 & 82.8 & 12 & $12,320,000^{\mathrm{a}}$ & wet \\
\hline-0.25 & 82.8 & 12 & $13,227,000^{\mathrm{a}}$ & wet \\
\hline-0.25 & 82.8 & 12 & $13,226,000^{\mathrm{a}}$ & wet \\
\hline-0.25 & 82.8 & 12 & $10,946,000^{\mathrm{a}}$ & wet \\
\hline
\end{tabular}

Runout, no faiture.

$b_{T}=27^{\circ} \mathrm{C}\left(70^{\circ} \mathrm{F}\right)$, R.H. $=50 \%$.

${ }^{\mathrm{C}} \mathrm{T}=49^{\circ} \mathrm{C}\left(120^{\circ} \mathrm{F}\right)$, R.H. $_{\bullet}=98 \%$. 
TABLE 17 (cont.)

\begin{tabular}{|c|c|c|c|c|}
\hline \multirow[b]{2}{*}{ R Ratio } & \multicolumn{2}{|c|}{ Stress Level } & \multirow{2}{*}{$\begin{array}{l}\text { Cycles to } \\
\text { Failure }\end{array}$} & \multirow{2}{*}{$\begin{array}{c}\text { Test } \\
\text { Conditions } \\
\end{array}$} \\
\hline & $\mathrm{MPa}$ & $\mathrm{ksi}$ & & \\
\hline-0.5 & 172.5 & 25 & 14,851 & RTD $^{b}$ \\
\hline-0.5 & 172.5 & 25 & 7,124 & RTD \\
\hline-0.5 & 172.5 & 25 & 46,009 & RTD \\
\hline-0.5 & 172.5 & 25 & 79,346 & RTD \\
\hline-0.5 & 82.8 & 12 & $17,348,000^{\mathrm{a}}$ & RTD \\
\hline-0.5 & 82.8 & 12 & $10,000,000^{\mathrm{a}}$ & wet $^{\mathrm{C}}$ \\
\hline-0.5 & 82.8 & 12 & $10,200,000^{a}$ & wet \\
\hline-0.5 & 82.8 & 12 & $10,460,000^{\mathrm{a}}$ & wet \\
\hline-0.5 & 82.8 & 12 & $10,773,000^{a}$ & wet \\
\hline-1.0 & \pm 172.5 & \pm 25 & 142 & RTD \\
\hline-1.0 & \pm 172.5 & \pm 25 & 569 & RTD \\
\hline-1.0 & \pm 172.5 & \pm 25 & 4,211 & RTD \\
\hline-1.0 & \pm 172.5 & \pm 25 & 19,846 & RTD \\
\hline-1.0 & \pm 55.2 & \pm 8 & $10,500,000^{\mathrm{a}}$ & RTD \\
\hline-1.0 & \pm 55.2 & \pm 8 & $10,140,000^{\mathrm{a}}$ & RTD \\
\hline-1.0 & \pm 55.2 & \pm 8 & $12,318,000^{\mathrm{a}}$ & RTD \\
\hline-7.0 & \pm 55.2 & \pm 8 & $15,010,000^{\mathrm{a}}$ & RTD \\
\hline-1.0 & \pm 172.5 & \pm 25 & 2,839 & wet \\
\hline-1.0 & \pm 172.5 & \pm 25 & 14,074 & wet \\
\hline-1.0 & \pm 172.5 & \pm 25 & 17,347 & wet \\
\hline-1.0 & \pm 172.5 & \pm 25 & 736 & wet \\
\hline-1.0 & \pm 55.2 & \pm 8 & $12,400,000^{\mathrm{a}}$ & wet \\
\hline-1.0 & \pm 55.2 & \pm 8 & $11,000,000^{\mathrm{a}}$ & wet \\
\hline-1.0 & \pm 55.2 & \pm 8 & $13,710,000^{\mathrm{a}}$ & wet \\
\hline-1.0 & \pm 55.2 & \pm 8 & $10,160,000^{\mathrm{a}}$ & wet \\
\hline
\end{tabular}

Runout, no failure.

$b_{T}=21{ }^{\circ} \mathrm{C}\left(70^{\circ} \mathrm{F}\right)$, R. H. $=50 \%$.

$\mathrm{C}_{\mathrm{T}}=49^{\circ} \mathrm{C}\left(120^{\circ} \mathrm{F}\right)$, R.H. $=98 \%$. 
TABLE 18. FATIGUE ENDURANCES FOR EPOXY MATRIX MATERIAL WITH WINDING PATTERN NO. 2 AT VARIOUS R RATIOS

\begin{tabular}{|c|c|c|c|c|}
\hline \multirow[b]{2}{*}{ R Ratio } & \multicolumn{2}{|c|}{ Stress Level } & \multirow{2}{*}{$\begin{array}{l}\text { Cycles to } \\
\text { Failure }\end{array}$} & \multirow{2}{*}{$\begin{array}{c}\text { Test } \\
\text { Conditions } \\
\end{array}$} \\
\hline & $\mathrm{MPa}$ & $\mathrm{ksi}$ & & \\
\hline 0 & 103.5 & 15 & $5,160,000$ & $\operatorname{RTD}^{\mathrm{b}}$ \\
\hline 0 & 103.5 & 15 & $2,115,000$ & RTD \\
\hline 0 & 103.5 & 15 & $2,138,000$ & RTD \\
\hline 0 & 103.5 & 15 & $2,105,000$ & RTD \\
\hline 0 & 207 & 30 & 18,134 & RTD \\
\hline 0 & 207 & 30 & 19,847 & RTD \\
\hline 0 & 207 & 30 & 18,853 & RTD \\
\hline 0 & 207 & 30 & 13,136 & RTD \\
\hline 0 & 310.5 & 45 & 136 & RTD \\
\hline 0 & 310.5 & 45 & 204 & RTD \\
\hline 0 & 310.5 & 45 & 328 & RTD \\
\hline 0 & 310.5 & 45 & 238 & RTD \\
\hline 0 & 103.5 & 15 & $10,360,000^{\mathrm{a}}$ & wet ${ }^{c}$ \\
\hline 0 & 103.5 & 15 & $10,500,000^{a}$ & wet \\
\hline 0 & 103.5 & 15 & $973,000^{d}$ & wet \\
\hline 0 & 103.5 & 15 & $10,170,000^{\mathrm{a}}$ & wet \\
\hline 0 & 82.8 & 12 & $10,133,000^{\alpha}$ & wet \\
\hline \multicolumn{5}{|c|}{$\begin{array}{l}\mathrm{a}_{\text {Runout, no failure. }} \\
\mathrm{b}_{\mathrm{T}}=21^{\circ} \mathrm{C}\left(70^{\circ} \mathrm{F}\right), \mathrm{R}_{.} \mathrm{H}_{\bullet}=50 \% \\
\mathrm{C}_{\mathrm{T}}=49^{\circ} \mathrm{C}\left(120^{\circ} \mathrm{F}\right), \mathrm{R}_{\cdot} \mathrm{H}_{\bullet}=98 \% \\
\mathrm{~d}_{\text {Tab area failure. }}\end{array}$} \\
\hline
\end{tabular}


TABLE 18 (cont.)

\begin{tabular}{|c|c|c|c|c|}
\hline \multirow[b]{2}{*}{ R Ratio } & \multicolumn{2}{|c|}{ Stress Level } & \multirow{2}{*}{$\begin{array}{l}\text { Cycles to } \\
\text { Failure }\end{array}$} & \multirow{2}{*}{$\begin{array}{c}\text { Test } \\
\text { Conditions } \\
\end{array}$} \\
\hline & $\mathrm{MPa}$ & $\mathrm{ksi}$ & & \\
\hline-0.1 & 172.5 & 25 & 21,135 & RTD \\
\hline-0.1 & 172.5 & 25 & 7,590 & RTD \\
\hline-0.1 & 172.5 & 25 & $100,000^{\mathrm{a}}$ & RTD \\
\hline-0.1 & 172.5 & 25 & 19,898 & RTD \\
\hline-0.1 & 82.8 & 12 & $10,442,000^{\mathrm{a}}$ & RTD \\
\hline-0.1 & 103.5 & 15 & $1,500,000^{b}$ & Wet \\
\hline-0.1 & 103.5 & 15 & $1,500,000^{b}$ & Wet \\
\hline-0.1 & 103.5 & 15 & $1,500,000^{b}$ & Wet \\
\hline-0.1 & 103.5 & 15 & $1,500,000^{b}$ & Wet \\
\hline-0.1 & 82.8 & 12 & $10,694,000^{2}$ & Wet \\
\hline-0.25 & 82.8 & 12 & $13,654,000^{\mathrm{a}}$ & RTD \\
\hline-0.25 & 82.8 & 12 & $15,182,000^{\mathrm{a}}$ & RTD \\
\hline-0.25 & 82.8 & 12 & $10,079,000^{\mathrm{a}}$ & RTD \\
\hline-0.25 & 82.8 & 12 & $10,081,000^{\mathrm{a}}$ & RTD \\
\hline-0.25 & 82.8 & 12 & $10,313,000^{\mathrm{a}}$ & RTD \\
\hline-0.25 & 82.8 & 12 & $10,010,000^{\mathrm{a}}$ & Wet \\
\hline-0.25 & 82.8 & 12 & $10,007,000^{\mathrm{a}}$ & Wet \\
\hline-0.25 & 82.8 & 12 & $10,578,000^{\mathrm{a}}$ & Wet \\
\hline-0.25 & 82.8 & 12 & $10,576,000^{\mathrm{a}}$ & Wet \\
\hline-0.25 & 82.2 & 12 & $10,383,000$ & Wet \\
\hline
\end{tabular}

a Runout, no failure.

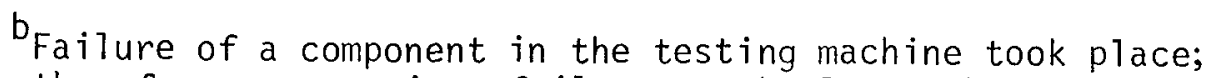
therefore, no specimen failures took place. The samples were not reinserted after repairs although no visible damage was observed. 
TABLE 18 (cont.)

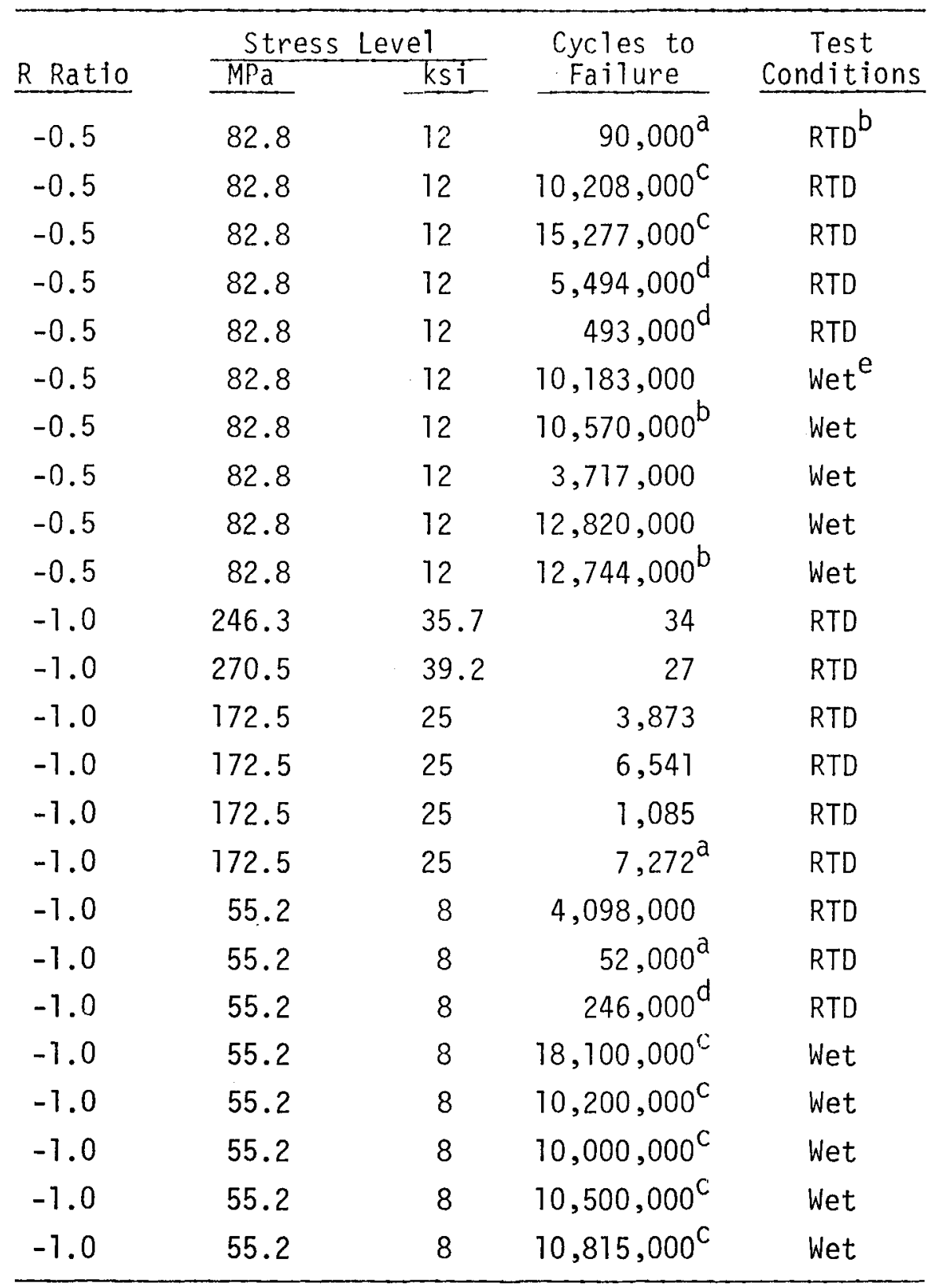

${ }^{a}$ No failure, tabs disbonded.

$b_{T}=21^{\circ} \mathrm{C}\left(70^{\circ} \mathrm{F}\right)$, R.H. $=50 \%$.

${ }^{c}$ Runout, no failure.

${ }^{d}$ No failure, bolts in grips failed.

$\mathrm{e}_{\mathrm{T}}=49^{\circ} \mathrm{C}\left(120^{\circ} \mathrm{F}\right)$, R.H. $=98 \%$. 
TABLE 19. FATIGUE ENDURANCES FOR POLYESTER MATRIX MATERIALS AT VARIOUS R RATIOS

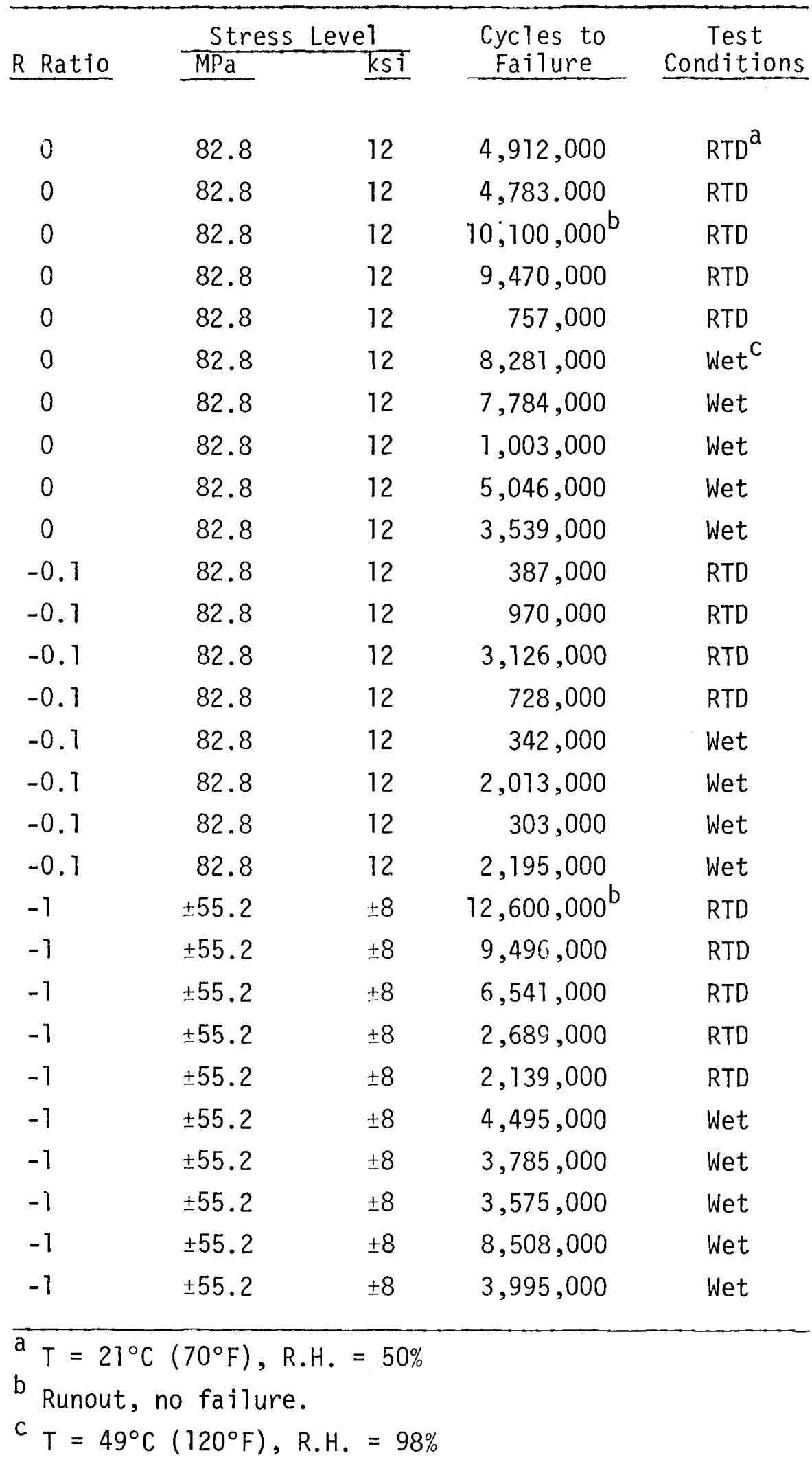





\begin{tabular}{|c|c|c|}
\hline $\begin{array}{l}\text { 1. Report No. } \\
\text { NASA CR-165566 }\end{array}$ & 2. Government Accession No. & 3. Recipient's Catalog No. \\
\hline \multirow{2}{*}{\multicolumn{2}{|c|}{$\begin{array}{l}\text { 4. Title and Subtitle } \\
\text { FATIGUE TESTING OF LOW-COST FIBERGLASS COMPOSTTE WIND } \\
\text { TURBINE BLADE MATERIALS }\end{array}$}} & $\begin{array}{l}\text { 5. Report Date } \\
\text { November } 1981\end{array}$ \\
\hline & & $\begin{array}{l}\text { 6. Performing Organization Code } \\
776-33-41\end{array}$ \\
\hline \multirow{2}{*}{\multicolumn{2}{|c|}{$\begin{array}{l}\text { 7. Author(s) } \\
\text { K. E. Hofer and L. C. Bennett }\end{array}$}} & $\begin{array}{l}\text { 8. Performing Organization Report No. } \\
\text { IITRI-M06066-22 }\end{array}$ \\
\hline & & 10. Work Unit No. \\
\hline \multicolumn{2}{|l|}{ 9. Performing Organization Name and Address } & \\
\hline \multirow{2}{*}{\multicolumn{2}{|c|}{$\begin{array}{l}\text { חT Research Institute } \\
10 \text { West } 35 \text { th Street } \\
\text { Chic ago, Illinois } 60616\end{array}$}} & $\begin{array}{l}\text { 11. Contract or Grant No. } \\
\text { DEN } 3-182\end{array}$ \\
\hline & & 13. Type of Report and Period Covered \\
\hline \multirow{2}{*}{\multicolumn{2}{|c|}{$\begin{array}{l}\text { 12. Sponsoring Agency Name and Address } \\
\text { U. S. Department of Energy } \\
\text { Wind Energy Technology Division } \\
\text { Washington, D. C. } 20545\end{array}$}} & Contractor R eport \\
\hline & & $\begin{array}{l}\text { 14. Sponsoring Agency Report No. } \\
\text { DOE/NASA/0182-1 }\end{array}$ \\
\hline \multicolumn{3}{|c|}{$\begin{array}{l}\text { 15. Supplementary Notes } \\
\text { Final Report. Prepared under Interagency Agreement DE-AI01-79ET20320. Project Manager, R. F. Lark, } \\
\text { Wind Energy Project Office, NASA Lewis Research Center, Cleveland, Ohio } 44135 \text {. }\end{array}$} \\
\hline
\end{tabular}

16. Abstract

The static and fatigue behavior of transverse filament tape (TFT) fibergiass/epoxy and TFT/polyester composites was established by the testing of specimens cut from panels fabricated by a filament winding process used for the construction of large experimental wind turbine blades. Static mechanical properties ob tained included tension, compression, and interlaminar shear at ambient conditions in high-humidity/ high-temperature conditions after a 500-hour exposure to such an environment. The fatigue data were obtained at similar environmental exposures and at several $R$ ratios including $R=0,0.1,-0.25,-0.5$, and -1. Negative ratios imply a compressive component of stress. Testing was performed to failure in $m$ any cases. S-N diagrams and a modifled Goodman constant life plot were obtained for one of two types of the epoxy matrix composites. The elastic properties of the epoxy matrix materials showed a strong dependence only on the filament stiffness and angle and a weak influence of the high-humidity/high-temperature environment. The polyester materials showed a substantial decrease in compressive strength for some composites which had been exposed for over 4000 hours in the high-humidity/high-temperature environment.

17. Key Words (Suggested by Author(s))

Wind energy conversion systems, laminated composites, windmills, fiberglass/polyester, fatigue, fiberglass/epoxy, wind turbine blades
18. Distribution Statement

Unclassified - unlimited

STAR C ategory 44

DOE Category UC-60 

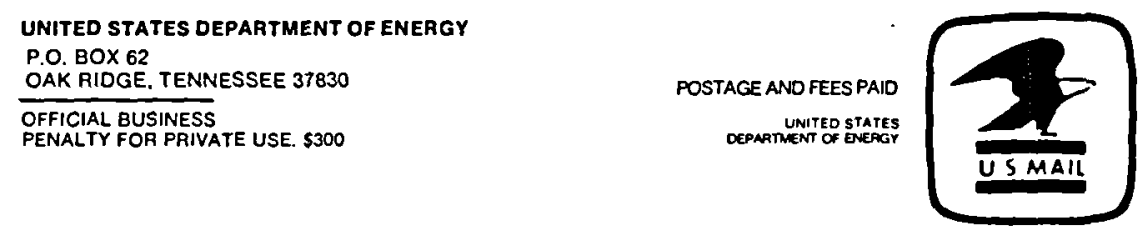

$$
528
$$$$
F S-1
$$

NATIONAL AEFONAUTICS AND SFACE. HIM

ATTN LIBRAETY

LANGLEY FESEAFCH CENTEF

HAMFTON, VA 23665 